\title{
Neighborhood quality and labor market outcomes: Evidence from quasi-random neighborhood assignment of immigrants iै $^{\text {th }}$
}

\author{
Anna Piil Damm \\ Department of Economics and Business, Aarhus University, Fuglesangs Allé 4, 8210 Aarhus V., Denmark
}

\section{A R T I C L E I N F O}

Article history:

Available online 13 September 2013

\section{JEL classification:}

J60

J31

R30

Keywords:

Residential job search networks

Referral

Contacts

Neighborhood quality

Labor market outcomes

\begin{abstract}
A B S T R A C T
Settlement in a socially deprived neighborhood may hamper individual labor market outcomes because of lack of employed or highly skilled contacts. I investigate this hypothesis by exploiting a unique natural experiment that occurred between 1986 and 1998 when refugee immigrants to Denmark were assigned to municipalities quasi-randomly, which successfully addresses the methodological problem of endogenous neighborhood selection. I show that individuals sort into neighborhoods. Taking account of location sorting, living in a socially deprived neighborhood does not affect labor market outcomes of refugee men. Their labor market outcomes are also not affected by the overall employment rate and the overall average skill level in the neighborhood. However, an increase in the average skill level of non-Western immigrant men living in the neighborhood raises their employment probability, while an increase in the employment rate of co-national men living in the neighborhood raises their real annual earnings. This provides quasi-experimental evidence that residence-based job information networks are ethnically stratified.
\end{abstract}

(c) 2013 Elsevier Inc. All rights reserved.

\section{Introduction}

Widespread use of friends, relatives and acquaintances to search for jobs is a stylized fact. ${ }^{1}$ Personal contacts may convey information about job vacancies and recommend friends, relatives and acquaintances with similar personal characteristics as themselves to their employer. For employers, job referrals lower the search costs as well as the screening costs of applicants. For employees, job referral may speed up the job-finding process and, as sug-

\footnotetext{
I have benefited from helpful comments and suggestions from two anonymous referees, Stuart S. Rosenthal, Tor Eriksson, Nabanita Datta Gupta, Christian Dustmann, Jonathan Wadsworth, Giovanni Peri, Michael Rosholm, Peter Jensen, Astrid Würtz Rasmussen and participants at the II Workshop on Urban Economics 2012, the NORFACE Migration Conference "Migration: Economic Change, Social Change" 2011, the EEA/ESEM Conference 2011, the CReAM workshop, September 2010, the Danish Microeconometric Network Workshop, Skagen 2010, the Aarhus University Immigration Workshop, November 2010, the VATT seminar in Helsinki, May 2010, the ECON ASB Seminar, December 2010 and the CIM workshop, August 2008. This research was carried out in collaboration with the Rockwool Foundation Research Unit and the Danish National Centre for Social Research. I thank Margrethe L. Thuesen and Charlotte Duus for research assistance. The project was financed by a grant from the Strategic Research Program for Welfare Research for the project "Integration of ethnic minorities", Grant 24-03-0288 from the Danish Research Agency and a grant from the NORFACE program on Migration.

E-mail address: apd@asb.dk

1 See Rees (1966), Granovetter (1974, 1995), Holzer (1988), Blau and Robins (1990), Montgomery (1991), Gregg and Wadsworth (1996), Topa (2001), Addison and Portugal (2002), Wahba and Zenou (2005), Bentolila et al. (2010) and Pellizari (2010).
}

gested by Dustmann et al. (2011) lead to a short-termed wage premium due to reduced uncertainty about the worker productivity.

According to recent social network theories the quality of personal contacts is of key importance for job referral (Montgomery, 1994; Calvó-Armengol and Jackson, 2004). ${ }^{2}$ The higher the quality of personal contacts, the more useful the contacts are for job referral.

My main research question is whether the quality of the job information network affects labor market outcomes. In the first part of my analysis I provide tentative evidence from the Welfare Research Survey conducted in Denmark in 2006 among representative samples of natives and immigrants that the quality for contacts matters: unemployed respondents whose acquaintances (e.g. friends of friends, co-workers and neighbors) have a high employment rate have a higher job-finding rate, after controlling for other personal characteristics and area characteristics. Job seekers may thus receive information about job vacancies from employed neighbors among others. Therefore, living in a neighborhood with more unemployment may reduce job chances. If so, concentration of unemployed workers in certain neighborhoods increases employment inequality in society (see e.g. Montgomery, 1994). Results from studies using observational data are consistent with neighborhood job referral, i.e. individuals who live in the same or adjacent neighborhoods sometimes refer each other to jobs. ${ }^{3}$ By

\footnotetext{
2 By contrast, Granovetter $(1973,1974,1995)$ argues that it is the quantity of weak ties which matters for job referral.

3 See e.g. Topa (2001), Weinberg et al. (2004), Bayer et al. (2008), Andersson et al. (2009) and Hellerstein et al. (2011).
} 
contrast, quasi-experimental and experimental studies find little role of neighborhood quality on adult labor outcomes. ${ }^{4}$

I argue that the Danish Spatial Dispersal Policy on Refugees which operated from 1986 until 1998 is an ideal quasi-experiment for investigation of whether the quality of the neighborhood matters for individual labor market outcomes. At the time of receipt of asylum, placement officers working in the central office of the Danish Refugee Council assigned refugee families to housing in different locations in Denmark, exclusively on the basis of a questionnaire with personal information like household size. The placement officers did not meet face to face with refugees at the time of assignment. I observe all personal characteristics known to the placement officers in the administrative registers used for the analysis and condition on them in the regressions. Conditional on these personal characteristics, characteristics of the neighborhood of assignment are valid instruments for characteristics of the current neighborhood of residence. Moreover, the approximately 15,400 refugee men subjected to the spatial dispersal policy were assigned to as many as 1710 different neighborhoods located in 245 different municipalities. ${ }^{5}$ In other words, the Danish Spatial Dispersal Policy provides extensive geographic variation in neighborhood characteristics which is an important strength relative to the existing quasi-experimental and experimental studies of neighborhood job referral.

Therefore, in the second part of my analysis I use detailed administrative register data for the sample of refugee men who had initially been assigned to a neighborhood by the Danish Refugee Council to provide quasi-experimental evidence on the quality of job information networks on individual labor market outcomes. To proxy for social interactions, I use neighborhoodbased networks, i.e. connections between individuals living in the same neighborhood, in line with a number of previous studies. $^{6}$ In particular, I provide two-stage least squares (2SLS) estimates of the causal effects of living in a socially deprived neighborhood on individual labor market outcomes. I define a neighborhood as socially deprived if the employment rate is at most $60 \%$. As instrument for the indicator for current residence in a socially deprived neighborhood I use an indicator for assignment to a socially deprived neighborhood. Next, I estimate the effects of alternative, continuous measures of neighborhood quality (employment rates, average skill level, mean real annual earnings) and compare ordinary least squares (OLS) and propensity score matching (PSM) estimates to quasi-experimental results from instrumental variables (IV) estimation.

Using observational data, the studies by Topa (2001) and Hellerstein et al. (2011) find empirical evidence that residence-based job search networks are ethnically stratified. In that case the quality of the co-ethnic network should matter more for individual labor market outcomes than the overall quality of the neighborhood. In the third part of the analysis, I exploit the Spatial Dispersal Policy on Refugees to provide quasi-experimental evidence on the effects of the quality of the immigrant and co-ethnic networks on labor market outcomes of refugees. As before, I use the detailed administrative register data for the sample of refugee men who had initially been assigned to a neighborhood by the Danish Refugee Council. However, to proxy for social interactions, I follow Borjas (1995) and use neighborhood-based immigrant and co-ethnic networks, i.e. defined as connections between individuals of

\footnotetext{
${ }^{4}$ See the quasi-experimental study by Oreopoulos (2003) and evaluations of the Moving to Opportunity Program by Katz et al. (2001), Kling et al. (2007), Sanbonmatsu et al. (2011) and Ludwig et al. (2012).

${ }^{5}$ In the observation period, Denmark was divided into 275 municipalities (local authorities), on average inhabited by 19,562 individuals (in 2004).

${ }^{6}$ See Topa (2001), Weinberg et al. (2004), Bayer et al. (2008), Andersson et al (2009), Hellerstein et al. (2011), Oreopoulos (2003), Katz et al. (2001), Kling et al. (2007), Sanbonmatsu et al. (2011) and Ludwig et al. (2012).
}

immigrant origin/the same national origin living in the same neighborhood. ${ }^{7}$ Specifically, I present 2 SLS estimates of the effects of the quality of immigrant/co-ethnic men living in the neighborhood on individual labor market outcomes 2-6 years after immigration. As instruments I use the quality of immigrant/co-ethnic men living in the neighborhood of assignment in the year of assignment and an indicator for no other immigrant/co-ethnic men living in the neighborhood of assignment in the year of assignment. I measure quality in terms of the employment rate and the average skill level. Therefore, my paper combines two strands of literature: empirical network studies which use neighborhood-based networks and empirical network studies which use ethnicity-based networks. ${ }^{8}$

Previous studies on the impact of residence-based ethnic networks on labor market outcomes (Bertrand et al., 2000; Edin et al., 2003; Damm, 2009) use metropolitan areas/municipalities as the geographic unit of analysis. The empirical model used in these studies to identify the effect of the size as well as the interaction between the size and the quality of the ethnic group omits the quality of the local ethnic group; the direct effect of the quality of the local ethnic group is assumed to be captured by language/ country of origin fixed effect. By instead using neighborhoods, I can disentangle the effect of the quality from the size of the immigrant/co-ethnic network in contrast to previous studies.

Finally, to shed light on how long it takes for a new resident to become part of the established networks in the neighborhood, I investigate the speed at which network effects operate in the neighborhood using the detailed administrative registers for refugee men who were initially assigned to neighborhoods by the Danish Refugee Council.

The next section provides tentative evidence on the importance of the quality and quantity of contacts on individual employment from the Welfare Research Survey conducted in Denmark in 2006 among random samples of natives and non-Western immigrants. Section 3 describes the construction of a balanced panel of male refugees from administrative register data and presents OLS and PSM estimates of living in a socially deprived neighborhood six years after immigration for the individuals in the balanced panel of male refugees. It then describes the Danish Spatial Dispersal Policy on Refugees and exploits it to provide quasi-experimental evidence on the effects of living in a socially deprived neighborhood and the effects of continuous measures of neighborhood quality on individual labor market outcomes of male refugees. Section 4 presents quasi-experimental evidence on whether residence-based networks of male refugees are ethnically stratified and on the speed at which network effects operate in the neighborhood. Section 5 offers conclusions.

\section{Survey evidence on the importance of the social network for employment}

In this section I use the Welfare Research Survey linked with administrative registers from Statistics Denmark to shed light on which types of social networks are more useful for job referral. The Welfare Research Survey was conducted in Denmark from February to November 2006 among a random sample of 1000 natives aged 18-45 and a random sample of 1000 immigrants (i.e. foreignborn individuals whose parents are also foreign-born or have foreign citizenship) from each of the following source countries:

\footnotetext{
7 This approach is also related to the studies by Bertrand et al. (2000), Munshi (2003), Edin et al. (2003), Damm (2009) and Dustmann et al. (2011) which define the network as connections between individuals with the same language/national origin living in the same metropolitan area/municipality.

${ }^{8}$ Cingano and Rosolia (2012) instead use coworker-based networks. For an extensive summary of the economic literature on job information networks and neighborhood effects, see Ioannides and Loury (2004), Durlauf (2004) and Ross
} (2011) 
Table 1

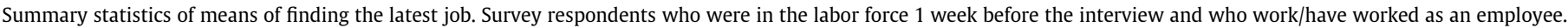
Source: Welfare Research Survey conducted by SFI Survey in Denmark in 2006.

\begin{tabular}{|c|c|c|c|c|}
\hline & \multirow{2}{*}{$\begin{array}{l}\text { Danes } \\
\text { All } \\
(1)\end{array}$} & \multicolumn{3}{|c|}{ Immigrants } \\
\hline & & $\begin{array}{l}\text { All } \\
(2)\end{array}$ & $\begin{array}{l}\text { Low-skilled } \\
\text { (3) }\end{array}$ & $\begin{array}{l}\text { Highly skilled } \\
\text { (4) }\end{array}$ \\
\hline \multicolumn{5}{|l|}{ Panel A: Means of finding the latest job (\%) } \\
\hline Direct search channel & 70.5 & 66.7 & 60.3 & 68.7 \\
\hline Network & 16.6 & 26.3 & 36.0 & 23.3 \\
\hline Other & 12.9 & 7 & 3.8 & 8.0 \\
\hline Sum & 100.0 & 100.0 & 100.1 & 100.0 \\
\hline Number of observations & 668 & 987 & 239 & 747 \\
\hline \multicolumn{5}{|c|}{ Panel B: Direct search channel used to find the latest job (\%) } \\
\hline Employment agency & 13.8 & 28.7 & 44.4 & 24.4 \\
\hline Direct application to employer & 44.2 & 44.2 & 38.2 & 45.8 \\
\hline Temp agency & 1.5 & 2 & 1.4 & 2.1 \\
\hline Spare-time job & 0.2 & 0.8 & 0.7 & 0.8 \\
\hline Reply to job advertisement in the media & 40.3 & 24.2 & 15.3 & 26.7 \\
\hline Unknown & 0 & 0.1 & 0 & 0.2 \\
\hline Sum & 100.0 & 100.0 & 100.0 & 100.0 \\
\hline Number of observations & 471 & 658 & 144 & 513 \\
\hline \multicolumn{5}{|c|}{ Panel C: Network channel used to find the latest job (\%) } \\
\hline Danish relatives & 19.1 & 1.5 & 0 & 2.3 \\
\hline Danish close friends & 47.3 & 14.6 & 5.8 & 18.9 \\
\hline Danish acquaintances & 33.6 & 8.1 & 5.8 & 9.2 \\
\hline Relatives of immigrant origin & - & 35.8 & 41.9 & 32.8 \\
\hline Close friends of immigrant origin & - & 31.2 & 36.0 & 28.7 \\
\hline Acquaintances of immigrant origin & - & 7.7 & 9.3 & 6.9 \\
\hline Unknown & - & 1.1 & 1.2 & 1.2 \\
\hline Sum & 100.0 & 100.0 & 100.0 & 100.0 \\
\hline Number of observations & 110 & 260 & 86 & 174 \\
\hline
\end{tabular}

Note: Only four Danish respondents are low-skilled.

Turkey, Iran or Pakistan. ${ }^{9}$ As part of the survey I collected information about labor force participants' job search channels and characteristics of their social network. The overall response rate was $60 \%$. Table 1 summarizes the job search channels used by respondents (874 Danes, 1575 immigrants). The majority of natives (71\%) and immigrants (67\%) had found their latest job by means of direct job search, mainly through "direct application to the employer". However, a substantial share of respondents had found their latest job by means of informal job search, i.e. through the social network (relatives, close friends or acquaintances): $16.6 \%$ of natives and $26.3 \%$ of immigrants survey respondents. ${ }^{10}$ The share of low-skilled immigrants (at most 9 years of education) who have found the latest job through their social network is even higher: $36 \%$. Using a unique person identifier I link the survey with the administrative registers from Statistics Denmark on individual demographic characteristics and educational attainment in 2006 and work experience from 1980 until 2004 (measured in number of years of full-time work). Moreover, I use the administrative registers to construct socio-economic characteristics of the individual's municipality of residence in 2006.

I have used the following survey questions to construct measures of the usefulness of the social network for job referral. First: "Do few or many of your (i) family members in Denmark, (ii) close friends in Denmark and (iii) other adult contacts have a job?" Sec-

\footnotetext{
9 The Welfare Research Survey is a cross-sectional micro data set for 2006 . The data collection process consisted of telephone interviews supplemented by face-to-face interviews conducted by SFI Survey. If possible, the interview was conducted in Danish and otherwise in Turkish, Farsi or Urdu. Therefore, insufficient host-country language skills were not a barrier to participation. See Deding et al. (2008) for a detailed examination of the determinants of non-response in the survey.

${ }^{10}$ These findings are in line with two previous Danish surveys which were conducted in 1996 for the general population and in 1998-1999 for the immigrant population (see Mogensen and Matthiessen, 2000). Compared to evidence for most other European countries and the US, the share of workers in Denmark who have found the latest job through the social network is rather low, possibly because formal job search channels are relatively efficient in Denmark, as argued by Pellizari (2010).
}

ond: "Which level of education does most of your (i) family members in Denmark, (ii) close friends in Denmark and (iii) other adult contacts have?" Third: "Approximately how many persons - besides family and friends - do you know or talk with on a normal day?" I construct an indicator for having a social network with a high employment rate which takes the value 1 if at least $50 \%$ of the members of a given social network category are employed, and 0 otherwise. Similarly, I construct an indicator for having a highly educated social network which takes the value 1 if at least $50 \%$ of the members of a given social network category have either vocational secondary education or tertiary education, and 0 otherwise. ${ }^{11}$

Table A1 summarizes the personal attributes and the municipality of residence characteristics of survey respondents separately for natives (column 1) and immigrants (column 2) as well as their self-reported individual characteristics including social network characteristics.

For native and immigrant respondents, separately, I regress an indicator for being employed (as self-employed, wage-employed, employed in a company owned by spouse or temporarily on leave from a job) in the week before the interview on the number of acquaintances (other adult contacts) and the indicators for having a social network with a high employment rate and a high skill level for each social network category, separately. Controlling for observed personal characteristics and socio-economic characteristics of the municipality of residence in the same year, I find a positive and significant association between the individual's employment probability and the employment rate of close friends and of acquaintances for both samples (see Table A2, columns 1-5). By contrast, the estimate of the number of acquaintances (standardized to have 0 mean and a standard deviation of 1 ) is insignificant in most specifications.

\footnotetext{
11 Moreover, I have constructed an indicator for the majority of the acquaintances being of immigrant origin from the next question in the survey: "Are most of these persons Danes or [own ethnic group]?"
} 
Next, in order to reduce the possible influence of reverse causality (i.e. having a job may increase the size and improve the quality of your social network), I limit my sample to survey respondents who did not have a job in the week before the interview (conducted from February to November 2006) but were looking for one, henceforth referred to as the sample of unemployed respondents (69 Danes, 263 immigrants). The drawback of using these subsamples is that they may be selective, since the Danish labor market was extremely tight in 2006. ${ }^{12}$ See Table A1, columns 3 and 4 , for summary statistics. Using the two subsamples for immigrants and Danes, I regress an indicator for being employed in November 2006 or November 2007 according to the administrative registers on their self-reported social network characteristics. 65\% of natives and $49 \%$ of immigrants were employed in November 2006 or November 2007, which means that they have found a job shortly after the interview. For native and immigrant respondents alike, I find that respondents whose acquaintances have a high employment rate are significantly more likely to find a job, after controlling for other personal characteristics and socio-economic characteristics of the municipality of residence (see Table A2, columns $6-10)$. The other social network characteristics are all statically insignificant.

Thus, my survey analysis offers tentative evidence that having acquaintances of which the majority are employed increases the job-finding rate. If individuals are sometimes referred to vacant jobs through contacts in their neighborhood, residents in socially deprived neighborhoods may have a lower employment probability than residents outside socially deprived neighborhoods, in part due to lack of employed contacts in the neighborhood. I now turn to empirical investigation of this hypothesis.

\section{Effects of living in a socially deprived neighborhood on individual labor market outcomes of refugees}

This section investigates empirically whether residence in a socially deprived neighborhood hampers individual labor market outcomes. The alternative hypothesis is that the adverse labor market outcomes of residents in socially deprived neighborhoods are entirely due to negative self-selection of individuals into these neighborhoods.

\subsection{Empirical models for estimation of effects of living in a socially deprived neighborhood}

In this section I propose two empirical models for estimation of labor market effects of neighborhood job referral. They are extensions of the empirical model proposed by Edin et al. (2003) for estimation of the earnings returns to living in an ethnic enclave (measured by the number of co-nationals living in an individual's municipality of residence) for refugees subject to spatial dispersal $^{13}$ :

$y_{i j k(t+s)}=\alpha \ln e_{j k(t+s)}+\boldsymbol{\beta}^{\prime} \boldsymbol{x}_{i t}+\boldsymbol{\delta}_{j^{*}}+\boldsymbol{\delta}_{k}+\boldsymbol{\delta}_{t}+\varepsilon_{i j k(t+s)}$

where the subscripts denote $i$ : individual, $j$ : current municipality of residence, $k$ : country of origin, $t$ : year of immigration (= year of assignment), $j^{*}$ : municipality of assignment (municipality of residence in year $t$ ) and $s$ : years since immigration. The dependent variable $y$ is either a dummy variable for individual $i$ living in municipality $j$ in year $t+s$ being employed in year $t+s$ or the individual's log real annual earnings in year $t+s$. The parameter of interest is $\alpha$, which measures the average effect of $\ln e_{j k(t+s)}$, i.e.

\footnotetext{
12 The (net) unemployment rate in full-time equivalents was 3.9\% (www.statistikbanken.dk/AULAAR).

13 Bertrand et al. (2000) use an empirical model similar to Eq. (1) to investigate the importance of residence-based ethnic networks for welfare participation.
}

the logarithmic value of the ethnic stock (i.e. number of co-nationals) in municipality $j$ at time $t+s$, on the individual's employment probability in year $t+s$ or real annual earnings in year $t+s$. Control variables are $\boldsymbol{x}$ : personal characteristics in year $\boldsymbol{t}$, and $\boldsymbol{\delta}$ : fixed effects for municipality of assignment, country of origin and year of assignment. $\varepsilon$ is the error term.

$\hat{\alpha}$ may suffer from omitted variables bias because of ability sorting into ethnic enclaves. To take account of ability sorting, Edin et al. (2003) exploit a Swedish spatial dispersal policy on refugees which resulted in quasi-random initial settlement of refugees. Therefore, they use the logarithmic value of the ethnic stock in the initial municipality in the year of assignment, $\ln e_{j * k}$, as instrument for $\ln e_{j * k(t+8)}$. The instrumental variables estimate of the effect of $\ln e_{j * k(t+8)}$ is obtained by 2SLS regression of $y$ on $e$, fixed effects for $j^{*}, k$, and $t$, and a set of controls for observed personal characteristics in year $t$. Similarly, Damm (2009) exploits the Danish spatial dispersal on refugees in place from 1986 until 1998 to argue that the inflow of placed co-nationals (aged 18-59) to individual $i$ 's municipality of assignment since the year of implementation of the dispersal policy until (the end of) year $t$ is a valid instrument for $\ln e_{j * k(t+7)}$, conditional on a few observed personal characteristics. Both studies provide quasi-experimental evidence of negative self-selection into ethnic enclaves, and taking account of location sorting, both studies find a positive and significant effect of ethnic enclave size on log real annual earnings in year $t+s$ for low-skilled and an insignificant effect for highly skilled. ${ }^{14}$

The first model I propose for estimation of labor market effects of neighborhood job referral for refugees subject to spatial dispersal at the time of asylum is the cross-section model in Eq. (2) which I will estimate for $s=6$, i.e. six years after neighborhood assignment:

$y_{i j k(t+s)}=\alpha_{1} \mathrm{D}_{j l(t+s)}+\boldsymbol{\beta}_{1}^{\prime} \boldsymbol{x}_{i t}++\boldsymbol{\gamma}_{1}^{\prime} \boldsymbol{v}_{j * t}+\boldsymbol{\delta}_{j^{*}}+\boldsymbol{\delta}_{k}+\boldsymbol{\delta}_{t}+e_{i j k(t+s)}$

Eq. (2) is obtained by adding an indicator D which takes the value 1 if the current neighborhood of residence of individual $i$ is socially deprived, and 0 otherwise, to Eq. (1). I define a neighborhood as socially deprived if the employment rate is at most $60 \%$ (see Section 3.2 for discussion). Another addition is the vector $\boldsymbol{v}$ which includes a number of observed characteristics of the municipality of assignment $j^{*}$ in year $t$, including the log of the ethnic stock in municipality $j^{*}$ (in the current study measured in percent of the number of inhabitants in the municipality $j^{*}$ and referred to as $\log$ percentage co-nationals). $e$ is an error term.

The cross-section model estimates the effects of living in a socially deprived neighborhood in year $t+s$ on labor market outcome $y$ in year $t+s$ by comparing labor market outcomes of individuals with the same observed personal characteristics and who were assigned to the same municipality in the same year $t$, but who are living in different neighborhoods in year $t+s . \boldsymbol{x}$ includes age and age squared as well as indicators for marital status, having a young child, having an old child and educational attainment (all measured in the year of assignment). $\boldsymbol{v}$ includes both socio-economic and demographic characteristics of the municipality of assignment, specifically log number of inhabitants, log average gross income, the unemployment rate, log percentage non-Western immigrants, and $\log$ percentage co-nationals. The neighborhood size is excluded from the set of controls, since neighborhoods are homogenous in the number of inhabitants. $\hat{\alpha}_{1}$ is a consistent estimate of

\footnotetext{
14 Notice that the quality of the local ethnic stock is excluded from the control set in Eq. (1) due to lack of variation in the quality of local ethnic stock after inclusion of country of origin dummies, $\delta_{k}$. Therefore, $\hat{\alpha}$ may be biased even after taking into account self-selection into ethnic enclaves. In Section 4 I show that this omitted variables problem can be solved by using neighborhoods as the geographic unit instead of municipalities because of sufficient neighborhood variation in the quality of the local ethnic stock to disentangle the effects of the quality and size of the local ethnic group.
} 
the effect of living in a socially deprived neighborhood in year $t+s$ if the neighborhood type in year $t+s$ is independent of the error term. This conditional independence assumption is very strong since refugees can move away from the assigned neighborhood any time after initial assignment as long as they are able to find housing elsewhere and since the relocation decision is likely to be influenced by unobserved, time-varying individual characteristics like host country and English language skills which also influence the individual's employment probability.

To take account of individual self-selection into neighbourhoods, I propose the following instrumental variables model, henceforth referred to as the IV-model:

$$
\begin{aligned}
y_{i j k(t+s)}= & \alpha_{2} \mathrm{D}_{j l(t+s)}+\boldsymbol{\beta}_{2}^{\prime} \boldsymbol{x}_{i t}+\gamma_{2}^{\prime} \boldsymbol{v}_{j * t}+\boldsymbol{\delta}_{j^{*}}+\boldsymbol{\delta}_{k}+\boldsymbol{\delta}_{t}+\boldsymbol{\delta}_{s}+\mu_{i} \\
& +u_{i j k(t+s)}
\end{aligned}
$$

$\mathrm{D}_{j l(t+s)}=\boldsymbol{\Pi}^{\prime} \boldsymbol{x}_{1 i t}+v_{i j k(t+s)}$

The IV-model differs from the cross-section model in Eq. (2) in two aspects. First, it is a panel data model which I estimate for $s=2, \ldots, 6$. $^{15}$ The panel feature allows me to include individual-specific random effects $\mu_{i}$ to control for unobserved, time-invariant individual characteristics like innate abilities. $\boldsymbol{\delta}_{s}$ are fixed effects for years since immigration. Second, it is an IV-model and therefore consists of a main equation for $y$ and a reduced form equation for D. To control for unobserved, time-varying individual characteristics which may be correlated with both $\mathrm{D}$ and $y$, e.g. language skills, I instrument $\mathrm{D}$ by $z$, excluded from $\boldsymbol{x}$. The instrument $z$ must satisfy two conditions: $z$ should be (i) uncorrelated with the error term in the main equation $u$ and (ii) a strong predictor of D. Apart from $z$, $\boldsymbol{x}_{1}$ includes $\boldsymbol{x}, \boldsymbol{v}, \boldsymbol{\delta}_{j}^{*}, \boldsymbol{\delta}_{k}, \boldsymbol{\delta}_{t}, \boldsymbol{\delta}_{s}$ and $\mu_{i}$. $v$ is an error term. The remaining variables and indices are the same as in Eq. (2).

I instrument $\mathrm{D}_{j l(t+s)}$ by an indicator for individual $i$ having been assigned to a socially deprived neighborhood in municipality $j^{*}$ in year $t$ under the Ordinary Danish Spatial Dispersal Policy on Refugees described in Section 3.4. In other words, the instrumental variable $z$ is an indicator denoted $D_{j * l * t}$ which takes the value 1 if the neighborhood of assignment $l^{*}$ in the municipality of assignment $j^{*}$ was socially deprived in the year of assignment $t$ and 0 otherwise. The identifying assumption is that refugees subject to the Ordinary Spatial Dispersal Policy were randomly distributed across neighborhoods, conditional on the observed personal attributes which were known to the placement officers and may therefore have affected the assignment to neighborhood type (age, marital status, number of children and source country as argued in Section 3.4).

The IV-model identifies the effect of living in a socially deprived neighborhood on labor market outcomes using variation for individuals who stayed in the neighborhood of assignment until year $t+s$. Thus, the IV-model compares labor market outcomes of individuals with the same observed personal characteristics and who were assigned to the same municipality in the same year $t$, but to different neighborhoods in year $t$ - and who have stayed in the neighborhood until year $t+s .{ }^{16}$ Under the assumption of

\footnotetext{
15 The reason for excluding the first two years is that refugees were encouraged to participate in Danish language courses during the first 18 months after receipt of asylum during which they received social assistance.

16 Suppose instead I had estimated Eq. (2) as a panel data model (for $s=2, \ldots, 6$ ) with individual fixed effects. In that case the effect of living in a socially deprived neighborhood would have been estimated using only variation for switchers, i.e. movers between socially deprived and non-socially deprived neighborhoods, yielding an inconsistent estimate for the following reasons. First, because all time-invariant explanatory variables drop out and, as a consequence, I cannot control for the individual characteristics at assignment which may have influenced the Council's neighborhood assignment decision. Second, due to omitted time-varying individual factors e.g. health changes. Third, because establishment of neighborhood networks takes time, in which case the effect of living in a socially deprived neighborhood has to be identified using variation for stayers as in Eq. (3).
}

homogenous treatment effects, the IV-estimate of living in a socially deprived neighborhood, $\hat{\alpha}_{2}$, is the average treatment effect of living in a socially deprived neighborhood for individuals in the balanced panel of male refugees.

Moreover, the instrument is a strong predictor if a substantial share of refugees remains in the neighborhood of assignment for some years. This will be investigated in Section 3.D. Moreover, to gauge the strength of instruments used in the IV-analyses in Sections 3.5, 3.6 and 4, I will employ the usual "rule of thumb" that the set of instrumental variables is strong if the F-statistic for joint insignificance of exclusion restrictions is 10 or above. However, in cases with just one excluded variable, I report the $t$-statistic for insignificance of the excluded variable in the first-stage regression and then calculate the $F$-statistic as the squared value of the $t$-statistic. The $t$-statistic for insignificance of the indicator for assignment to a socially deprived neighborhood in the first-stage regression is 10 (see Table 6), corresponding to an F-statistic of 100. Therefore, the instrument for living in a socially deprived neighborhood is indeed strong.

\subsection{Construction of the balanced panel of male refugees from administrative registers}

I link two primary data sources using a unique person identifier: (i) administrative register data from Statistics Denmark 1986-2004 and (ii) neighborhood of residence information from the Rockwool Foundation Research Unit for the entire population in Denmark 1985-2004. ${ }^{17}$ The neighborhoods are constructed on the basis of geo-referenced data provided by the National Square Grid - Denmark. The 431,233 inhabited hectare cells in Denmark are clustered into 2296 neighborhoods, on average inhabited by 2343 persons in 2004 . The neighborhoods are homogenous in terms of population size and housing type and delineated by physical barriers (like major roads, lakes and forests). ${ }^{18}$

Previous Danish studies define a socially deprived neighborhood as a neighborhood in which more than $40 \%$ of the workingage population receive public income transfers or the non-Western immigrant share exceeds 30\% (Andersen, 2005; Damm et al., 2006). Using this definition, 90 out of 2296 neighborhoods were socially deprived in 2004. The mean gross income is relatively low and the share of inhabitants who have committed a crime is relatively high in socially deprived neighborhoods (Damm et al., 2006). However, recent social network theory argues that what matters for individual labor market outcomes is the employment status of a neighbor and not whether or not the neighbor receives public income transfers. Therefore, I define a neighborhood as socially deprived if the employment rate in the working-age population (ages $18-60$ ) does not exceed $60 \%$, or equivalently as a neighborhood in which the jobless share in the working age population exceeds 40\%. According to my definition, 119 out of 2296 neighborhoods were socially deprived in $2004 .{ }^{19}$ In November $2004,82.8 \%$ of the overall population and $60 \%$ of non-Western immigrants in Denmark were employed. In that year $4.1 \%$ of the overall population in Denmark lived in a socially deprived neighborhood, while $24 \%$ of non-Western immigrants lived in a socially deprived neighborhood.

Ideally, estimation of the causal effect of living in a socially deprived neighborhood on individual labor market outcomes re-

\footnotetext{
17 In 2005, Anna P. Damm and Marie L. Schultz-Nielsen constructed neighborhoods for Denmark in collaboration with the Rockwool Foundation Research Unit.

18 See Damm and Schultz-Nielsen (2008) for a description of the criteria used for clustering inhabited hectare cells into neighborhoods.

19 Defining in addition a neighborhood as socially deprived if the non-Western immigrant share exceeds $30 \%$ would not add any neighborhoods to the set of socially deprived neighborhoods in the period 1986-1998, because they are already defined as socially deprived according to my definition.
} 
quires random assignment of individuals to socially deprived and non-deprived neighborhoods. Below I argue that such an experiment has been undertaken for newly recognized refugees who were subject to the ordinary Spatial Dispersal Policy on Refugees in Denmark in the period 1986-1998. Therefore, for this part of the analysis I extract a panel of all male non-Western immigrants aged 18-59 who immigrated in the period 1986-1998 from one of the eight largest refugee-sending countries (Lebanon, Iraq, Iran, Sri Lanka, Somalia, Vietnam, Afghanistan and Ethiopia). ${ }^{20}$ Refugees from these countries constitute more than $86 \%$ of the total number of permanent residence permits granted to refugees between 1985 and 1997. I exclude family-reunified immigrants by excluding individuals if (i) they were married to an individual from a non-refugee-sending country or (ii) immigrated more than a year later than the spouse. These selection criteria result in a balanced panel of 15,436 male refugees who are observed annually until six years after immigration.

Using a unique personal identifier, I link the information about the neighborhood of assignment (defined as the neighborhood of residence in the year of immigration) with the balanced panel of male refugees. Moreover, I link the balanced panel of male refugees with socio-economic characteristics of the municipality of assignment (defined as the municipality of residence in the year of immigration).

Summary statistics (initial values) of the balanced panel of male refugees are shown in Appendix Table A3. Six years after immigration $35.2 \%$ of male refugees live in a socially deprived neighborhood; their employment rate of $24.8 \%$ is much lower than that of refugee men living in a non-deprived neighborhood (33.8\%).

\subsection{Least squares and propensity score matching estimates of the effects of living in a socially deprived neighborhood}

I estimate the effects of living in a socially deprived neighborhood for individuals in the balanced panel of male refugees according to the cross-section model in Eq. (2) using ordinary least squares (OLS) for two different outcomes: employment probability and real annual earnings. According to the estimates reported in Table 2, Panel A, living in a socially deprived neighborhood six years after immigration reduces the employment rate by 4.5 pct. points (column 1) and real annual earnings by $9.5-10.1 \%$ (column 4). Furthermore, according to the OLS estimates by skill group, irrespective of skill level living in a socially deprived neighborhood six years after immigration significantly reduces the employment probability (columns 2-3) and, for highly skilled refugees, it also reduces real annual earnings (columns 5-6).

For comparison, I have estimated the average treatment effect of living in a socially deprived neighborhood six years after immigration on individual labor market outcomes six years after immigration by propensity score matching (Rosenbaum and Rubin, 1983). Propensity score matching (PSM) identifies the average effect of living in a socially deprived neighborhood six years after immigration on individual labor market outcomes under the strong assumption of ignorable treatment assignment or selection on observables assumption, i.e. residence in a socially deprived neighborhood six years after immigration is associated only with observable variables at the time of immigration. Specifically, I have used nearest neighbor (1-1) matching with replacement using

\footnotetext{
${ }^{20}$ Refugees from Former Yugoslavia are excluded from my sample because - in contrast to refugees from other refugee-sending countries - they were initially granted provisional asylum and were therefore subject to a special dispersal policy of refugees implemented in 1993 (called the Bosnian program). Refugees subject to the Bosnian program were accommodated in refugee-reception centres and so-called refugee villages.
}

trimming (i.e. dropping treatment observations whose pscore is higher than the maximum of the controls) to ensure estimation over the region of common support. The propensity score is estimated using a logit model. The specifications used ensure balancing of the estimated pscore across all covariates. ${ }^{21}$ The PSM coefficient estimates for the full sample are reported in Table 2, Panel B (column 1: employment model, column 2: earnings model). The standard errors are corrected following the conditional variance formula (14) for nearest neighbor (1-1) matching in Abadie and Imbens (2006). According to the PSM coefficient estimates, living in a socially deprived neighborhood six years after immigration is associated with 3.5 percentage points lower employment rate and $10.8 \%$ lower real annual earnings.

The OLS and PSM estimates of the average effect of residence in a socially deprived neighborhood reported in Table 2 are very similar. However, they only have a causal interpretation if the selection on observables assumption holds. Fortunately, I can exploit the Ordinary Spatial Dispersal Policy on Refugees and use IV-techniques to test whether the negative statistical associations between residence in a socially deprived neighborhood and individual labor market outcomes reported in Table 2 are causal.

\subsection{Ordinary Danish spatial dispersal policy on refugees}

In 1986, the Danish Government, through the Danish Refugee Council (henceforth referred to as "the Council"), implemented a two-stage dispersal policy for asylum seekers who had their applications approved, i.e. refugees. ${ }^{22}$ The main objective was to disperse refugees across counties and municipalities according to the number of existing inhabitants. ${ }^{23}$ In a first step, the Council allocated refugees proportional to the number of inhabitants to counties; in a second step, and within counties, refugees were proportionally allocated to the number of inhabitants to municipalities (Danish Refugee Council, CIU, 1996, pp. 8-9). This policy was in place until the end of 1998. Over this thirteen-year period, 76,673 individuals were granted refugee status (Statistical Yearbook 1992, Table 60; Statistical Yearbook 1997, Table 68; Statistical Yearbook 2000, Table 55) and were allocated across municipalities by the Council.

Before approval of refugee status, asylum seekers lived in Red Cross Reception Centers spread across Denmark. About 10 days after receipt of asylum, those who were granted refugee status were assigned to temporary housing in one of Denmark's 15 counties by the central Council office (Danish Refugee Council, CIU, 1996, p. 9). After settlement in the assigned county, the local office of the Council assisted assigned refugees in finding permanent housing in one of the municipalities within the county.

At receipt of asylum, refugees needed to fill in a questionnaire, which was available to the Council when making the allocation decision. The questionnaire asked refugees to provide a few personal details: birth date, marital status, number of children, nationality, and language. Placement officers in the central Council office did not meet the refugees in person; dispersal decisions were made exclusively on the basis of the questionnaire information. For instance, the information about household composition was used

\footnotetext{
21 I have followed the procedure for balancing the estimate pscore proposed in Dehejia and Wahba (1999, p. 1058), i.e. added higher-order terms and interactions of the covariates until there are no significant differences in the estimated pscore between the two groups for all covariates.

22 Until June 2002, Denmark gave asylum to individuals who were defined as refugees according to the Geneva Convention and to individuals who would not qualify as refugees under the Convention, but who for other reasons should not be required to return to the home country ('de facto' refugees - see Coleman and Wadensjö, 1999, for details).

${ }^{23}$ Following the convention, I refer to a person who seeks asylum as an "asylum seeker", and to a person whose asylum status has been approved as a "refugee".
} 
Table 2

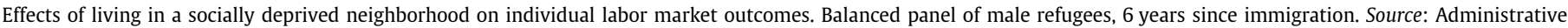
registers from Statistics Denmark.

\begin{tabular}{|c|c|c|c|c|c|c|}
\hline & \multicolumn{6}{|c|}{ Dependent variable } \\
\hline & \multicolumn{3}{|c|}{ Employed in November } & \multicolumn{3}{|c|}{ Ln(real annual earnings) } \\
\hline & $\begin{array}{l}\text { All } \\
(1)\end{array}$ & $\begin{array}{l}\text { Low-skilled } \\
(2)\end{array}$ & $\begin{array}{l}\text { Highly skilled } \\
(3)\end{array}$ & $\begin{array}{l}\text { All } \\
(4)\end{array}$ & $\begin{array}{l}\text { Low-skilled } \\
(5)\end{array}$ & $\begin{array}{l}\text { Highly skilled } \\
(6)\end{array}$ \\
\hline \multicolumn{7}{|l|}{$\begin{array}{l}\text { Panel A: OLS } \\
\text { Neighborhood of residence }\end{array}$} \\
\hline Socially deprived & $\begin{array}{l}-0.045^{* *} \\
(0.006)\end{array}$ & $\begin{array}{l}-0.023^{\dagger} \\
(0.012)\end{array}$ & $\begin{array}{l}-0.063^{* *} \\
(0.013)\end{array}$ & $\begin{array}{l}-0.095^{* *} \\
(0.046)\end{array}$ & $\begin{array}{l}-0.015 \\
(0.058)\end{array}$ & $\begin{array}{l}-0.140^{*} \\
(0.059)\end{array}$ \\
\hline $\mathrm{R}^{2}$ & 0.1157 & 0.1533 & 0.1049 & 0.0964 & 0.1479 & 0.1235 \\
\hline \multirow[t]{3}{*}{ Number of observations } & 15,436 & 6872 & 8564 & 5976 & 2503 & 3473 \\
\hline & \multicolumn{6}{|c|}{ Dependent variable } \\
\hline & \multicolumn{3}{|c|}{$\begin{array}{l}\text { Employed in November } \\
\text { All } \\
1^{\mathrm{a}}\end{array}$} & \multicolumn{3}{|c|}{$\begin{array}{l}\text { Ln(real annual earnings) } \\
\text { All } \\
2^{\mathrm{b}}\end{array}$} \\
\hline \multicolumn{7}{|l|}{$\begin{array}{l}\text { Panel B: Propensity score matching } \\
\text { Neighborhood of residence }\end{array}$} \\
\hline Socially deprived & \multicolumn{3}{|l|}{$\begin{array}{l}-0.035^{* *} \\
(0.011)\end{array}$} & \multicolumn{3}{|l|}{$\begin{array}{l}-0.108^{\dagger} \\
(0.061)\end{array}$} \\
\hline Number of observations on support & \multicolumn{3}{|l|}{15,246} & \multicolumn{3}{|l|}{5650} \\
\hline 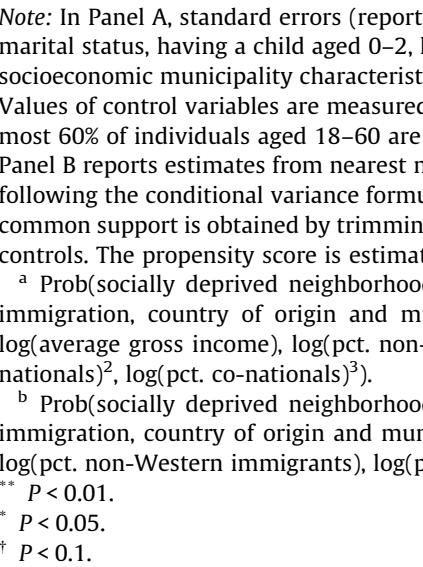 & $\begin{array}{l}\text { arentheses) } \\
\text { a child agec } \\
\text { (inhabitant } \\
\text { year of ass } \\
\text { yed): } 0.352 . \\
\text { r (1-1) mat } \\
\text { hearest neig } \\
\text { ample, i.e. d } \\
\text { ogit. The sp } \\
\text { F(age, age } \\
\text { lity of assi } \\
\text { n immigra } \\
F(\text { age, age } \\
\text { - of assign } \\
\text {-Western ir }\end{array}$ & $\begin{array}{l}\text { tered by mun } \\
\text { ducational att } \\
\text { ployment rate } \\
\text { Share of indi } \\
\text { ith replacemer } \\
\text {-1) matching i } \\
\text { treatment obs } \\
\text { ons are chose } \\
\text { d, having a cl } \\
\text { log(inhabitan } \\
\text { (pct. non-Wes } \\
\text { d, having a cl } \\
\text { (inhabitants) } \\
\text { ts })^{2} \text {, log(pct. c }\end{array}$ & $\begin{array}{l}\text { of assignment. } \\
\text { t, year of immig } \\
\text { jerage gross inco } \\
\text { living in a socia } \\
\text { tic estimation of } \\
\text { ie and Imbens ( } 2 \\
\text { ns whose pscore } \\
\text { sure balancing of } \\
\text { ed } 0-2 \text {, having } \\
\text { (inhabitants) } \\
\text { amigrants })^{2}, \log ( \\
\text { ed } 0-2, \text { having } \\
\text { habitants })^{2} \text {, une } \\
\text { nals), } \log (\text { pct. co }\end{array}$ & $\begin{array}{l}\text { hal controls } \\
\text { ountry of o } \\
\text { (pct. non- } \\
\text { ved neighb } \\
\text { pensity sco } \\
\text { timation of } \\
\text { r than the n } \\
\text { imated pscc } \\
\text { ged 3-17, } \\
\text { yment rat } \\
\text {-Western ir } \\
\text { ged 3-17, } \\
\text { ent rate, ur } \\
\text { ls) }{ }^{2} \text { ). }\end{array}$ & $\begin{array}{l}\text { l A: age and a } \\
\text { d municipality } \\
\text { immigrants) a } \\
\text { (defined as a } \\
\text { rimming. Stan } \\
\text { rage treatmen } \\
\text { n or less than } \\
\text { ll covariates: } \\
\text { rs for educat } \\
\text { ployment rat } \\
\text { ts) }{ }^{3} \text {, log(pct. } \\
\text { ors for educat } \\
\text { ment rate }{ }^{2} \text {, lc }\end{array}$ & $\begin{array}{l}\text { red, indicators } \\
\text { gnment as well } \\
\text { ct. co-nationals } \\
\text { rhood in which } \\
\text { ors are calculate } \\
\text { over the region } \\
\text { imum score of tl } \\
\text { tainment, year } \\
\text { mployment rate } \\
\text { nals), log(pct. c } \\
\text { tainment, year } \\
\text { ge gross income }\end{array}$ \\
\hline
\end{tabular}

to determine whether to search for housing for a single individual or a family. Hence, the Council's allocation may have been influenced by some of the information in the questionnaire, like family size. I observe all these characteristics in the analysis and condition on them. By contrast, the Council's allocation was not influenced by educational attainment or family income since the questionnaire did not ask about such personal details.

Note that the Council did not consider individual location wishes in the assignment process. However, a small fraction of refugees refused the offer of permanent housing in the location of assignment in which case the Council reassigned them to another location. I define the neighborhood of assignment as the initial neighborhood of residence observed in the administrative registers, i.e. the neighborhood of residence at the time of receipt of asylum. Re-assignment is only a minor concern for the instrumental variables analysis because, in the rare case of re-assignment, it typically took place after the initial move to the location of assignment, in which case the location of assignment is observed in the administrative registers.

After settlement in the location of assignment, refugees participated in Danish language courses during an introductory period of 18 months while receiving social assistance. Although individuals were urged to stay in the assigned municipality during the entire introductory period, there were no relocation restrictions. Individuals could move away from the municipality of assignment at any time, if they could find alternative housing elsewhere. Receipt of social benefits was unconditional on residing in the municipality of assignment.

The spatial dispersal policy was successful at dispersing immigrants. Refugees who got asylum in the period 1980-1984 primarily settled in one of the large cities (Copenhagen, Aarhus, Odense and Aalborg) (see Fig. 1). By contrast, refugees who got asylum in the period 1986-1998 were fairly evenly distributed across municipalities relative to the local population size as shown in Fig. 2. Moreover, the Council's Annual Report (Danish Refugee Council, 1987, p. 30-31) shows that only two years after the introduction of the dispersal policy refugees lived in 243 out of the 275 municipalities.

Table 3 shows that the dispersal policy had a very visible effect on the settlement pattern across neighborhood type (socially deprived or non-deprived) of refugees. It shows the geographical distribution across neighborhood type of the overall population in Denmark and non-Western immigrants in 1991 and individuals in the balanced panel of male refugees. The non-Western immigrant population was heavily overrepresented in socially deprived neighborhoods in 1991. 22.8\% of non-Western immigrants lived in such a neighborhood as compared to $3.9 \%$ of the overall population in Denmark. By contrast, as a consequence of the spatial dispersal policy on refugees, only $16.7 \%$ of individuals in the balanced panel of male refugees subject to the Ordinary Spatial Dispersal Policy on Refugees initially lived in a socially deprived neighborhood. Refugees were initially renters. However, as shown in Appendix 


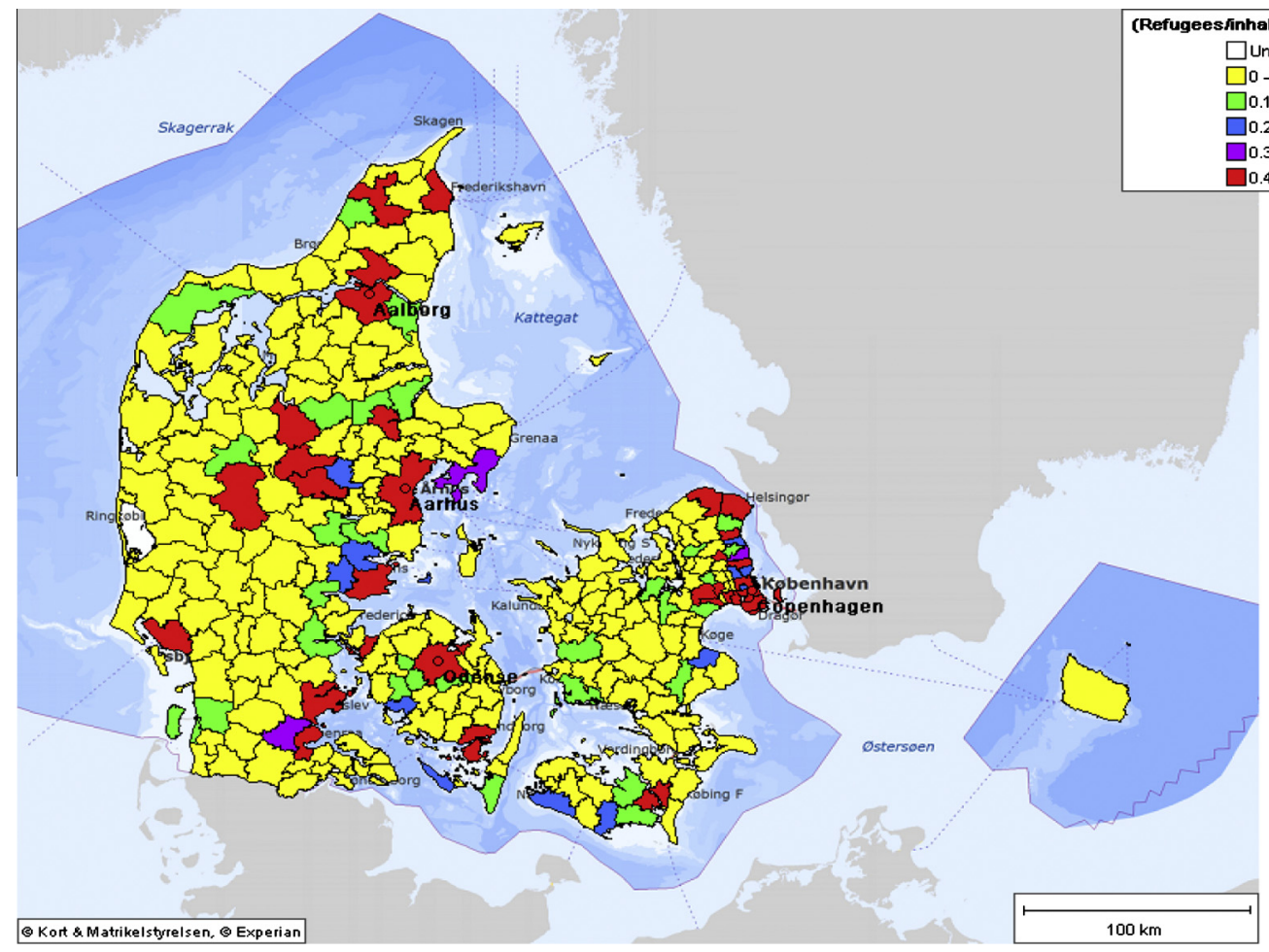

Fig. 1. Initial distribution of pre-reform refugees across municipalities (1980-1984).

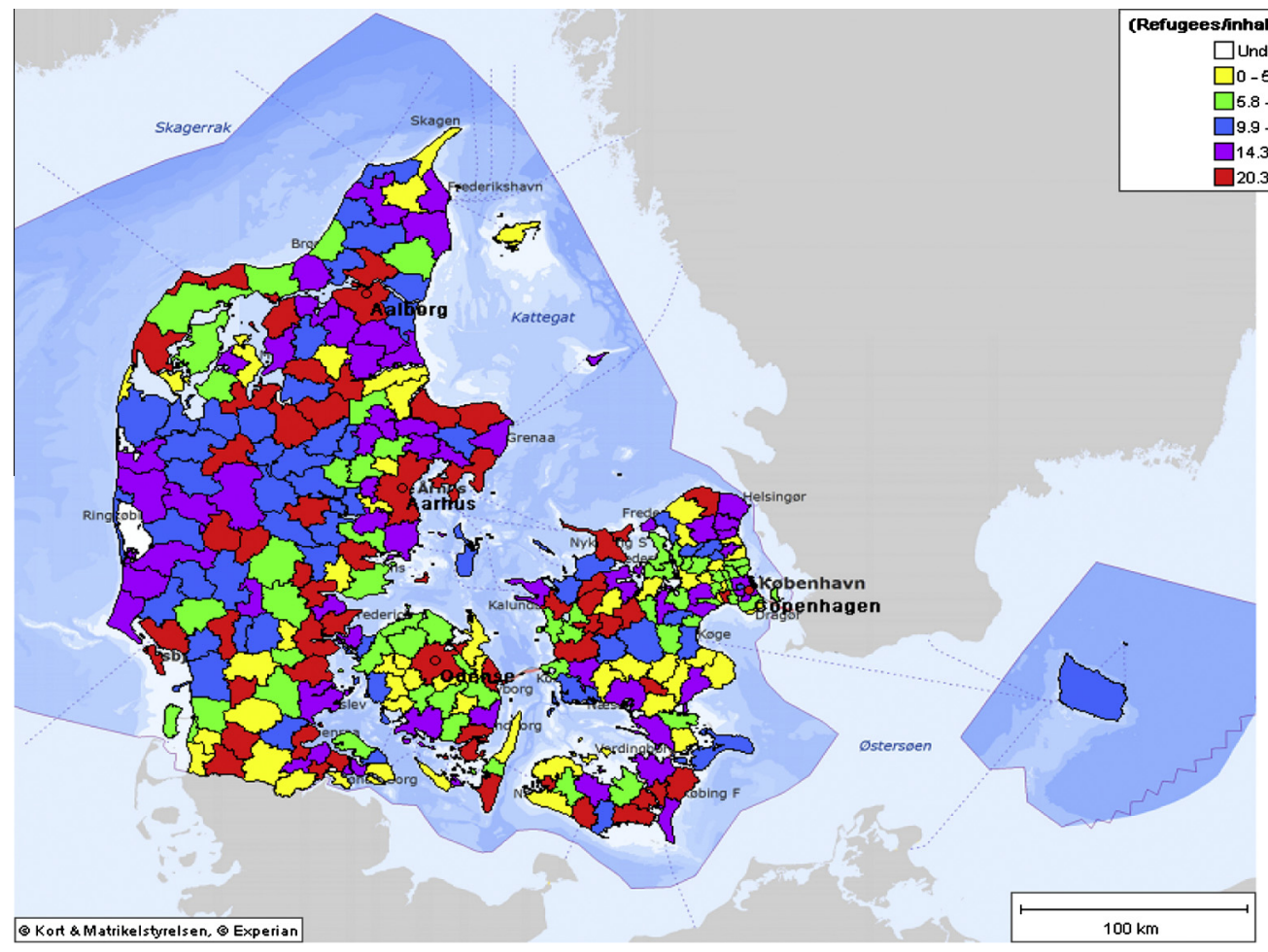

Fig. 2. Initial distribution of post-reform refugees across municipalities (1986-1998).

Table A3, refugee men assigned to a socially deprived neighborhood were initially overrepresented in large apartment blocks ( $88 \%$ vs. $42 \%$ ) and public housing units ( $81 \%$ vs. $23 \%$ ).

Next, I divide the individuals in the balanced panel of male refugees into two groups: (1) individuals assigned to (i.e. initially live in) a socially deprived neighborhood (2573 individuals, i.e. $16.7 \%)$ and (2) individuals assigned elsewhere (12,863 individuals). One can consider assignment to a socially deprived neighborhood by the authorities as a treatment and refer to the group of individuals who received treatment as the treatment group. 
Table 3

Geographical distribution across types of neighborhoods of the overall population in Denmark and subgroups of the population. Source: Administrative register data from Statistics Denmark.

\begin{tabular}{llll}
\hline & $\begin{array}{l}\text { Overall population in Denmark in } \\
1991\end{array}$ & $\begin{array}{l}\text { Non-Western immigrants in } \\
1991 \\
(1)\end{array}$ & $\begin{array}{l}\text { Initial residence of refugee men in the balanced } \\
\text { sample } \\
(3)\end{array}$ \\
\hline $\begin{array}{l}\text { Neighborhood type } \\
\text { Socially deprived }\end{array}$ & 3.9 & 22.8 & 16.7 \\
$\begin{array}{l}\text { Not socially } \\
\text { deprived }\end{array}$ & 96.1 & 77.2 & 83.3 \\
\hline
\end{tabular}

Note: A socially deprived neighborhood is defined as a neighborhood in which at most $60 \%$ of individuals aged $18-60$ are employed.

Individuals who were assigned to a non-deprived neighborhood constitute the control group. Individuals in the treatment group are assigned in the period $1986-1998$ to one of 166 socially deprived neighborhoods (many of which are adjacent). These socially deprived neighborhoods are located in the four Danish cities (Copenhagen, Aarhus, Odense and Aalborg) and 34 towns in Denmark ${ }^{24}$ and include immigrant-dense residential areas which are often mentioned in the Danish media because of incidents of e.g. vandalism. ${ }^{25}$ Maps of the socially deprived neighborhoods in the four largest municipalities are shown in Appendix Figs. A1A4. Each neighborhood consists of a number of hectare cells. Hectare cells marked with red are located in socially deprived neighborhoods while hectare cells marked with blue are located in nondeprived neighborhoods. In the analysis below neighborhoods are used as the spatial unit.

The implementation of the spatial dispersal policy gives no reason to believe that the allocation of refugees across neighborhoods has been in response to individual abilities. This is apparent from Table 4, where I report the mean values of personal attributes at the time of immigration of the treatment and control groups (columns 1 and 2) and a $t$-test of difference in means (third column) for individuals in the balanced panel of male refugees. The $t$-test of difference in means shows that there are no significant differences in educational attainment between the two groups. Older, married individuals with children aged 3-17 were initially overrepresented in socially deprived neighborhoods, because large apartments suitable for families are overrepresented in socially deprived neighborhoods. Furthermore, to test the assumption of quasi-random neighborhood assignment I first define 4 measures of the neighborhood of assignment in the year of assignment: the indicator $\mathrm{D}$ for the neighborhood being socially deprived, the log employment rate of men aged 18-60, the log mean years of education of men aged 18-60 and the log mean real annual earnings of men aged 18-60. See Appendix Table A4 for information about the means, standard deviation and correlations between these neighborhood characteristics over the 1986-1998 period. For individuals in the balanced panel of male refugees, I then regress each of these four neighborhood characteristics on the personal characteristics observed in the administrative registers and by the council at assignment (age, marital status, having a child aged $0-2$, having

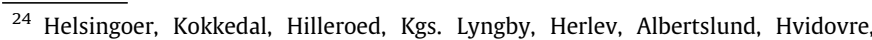
Broendby, Ishoej, Hoeje Taastrup, Hedehusene, Roskilde, Holbaek, Kalundborg, Korsoer, Slagelse, Naestved, Nakskov, Svendborg, Soenderborg, Haderslev, Esbjerg, Kolding, Fredericia, Vejle, Horsens, Silkeborg, Randers, Viborg, Holstebro, Nykoebing Mors, Thisted, Frederikshavn and Hjoerring.

25 My definition of socially deprived neighborhoods includes Tingbjerg and Lundtoftegade in Copenhagen, Taastrupgård, Vejleaaparken and Broendby Strand in the suburbs west of Copenhagen, Vollsmose in Odense, Byparken in Svendborg, Varbergparken in Haderslev, Kvaglund and Stengaardsvej in Esbjerg, Sundparken and Soenderbro in Horsens, Skovvejen/Skovparken in Kolding, Gellerupparken and Bispehaven in Aarhus and Sebbersundvej in Aalborg.
}

a child aged $3-17$, country of origin $)^{26}$ and on educational attainment, which is not observed by the council, conditional on year of immigration fixed effects.

I report the estimates from the balancing tests in Appendix Table A5, Part A, columns 1-4. The education variables are never statistically significant. Only the indicator for having at least one child aged 3-17 is statistically significant in one regression, most likely because it was easier for the council to find housing for large families in socially deprived neighborhoods.

A related question is whether some individuals were more likely to realize their preferred neighborhood choice than others. I investigate this question by analyzing whether the decision to move away from the neighborhood of assignment was affected by their educational attainment at the time of assignment, conditional on demographic individual characteristics as well as characteristics of the neighborhood of assignment and municipality of assignment. The results for individuals in the balanced panel of male refugees are reported in Table 5 . There are no significant differences in the probability of moving neighborhood between educational groups. $^{27}$

Together, the balancing tests in Table 4 and Appendix Table A5, the relocation results in Table 5 and the way in which the policy was implemented provide strong support for the refugee dispersal policy being quasi-random, conditional on the personal characteristics observed by the council. Therefore, the indicator for assignment to a socially deprived neighborhood should be a valid instrument for current residence in a socially deprived neighborhood controlling for observed personal characteristics, country of origin and year of immigration.

Another important issue is whether the indicator for assignment to a socially deprived neighborhood is a strong predictor for current residence in a socially deprived neighborhood up to six years after assignment. This depends on the extent to which refugees stayed in the neighborhood of assignment. As shown in Appendix Table A6, six years after assignment 50\% of individuals in the balanced panel of male refugees were still living in the municipality of assignment of which $28.8 \%$ were still living in the neighborhood of assignment. According to Table 5, assignment to

\footnotetext{
${ }^{26}$ Recall that the council assigned refugees on the basis of a questionnaire with information about the household heads: birth date, marital status, number of children, nationality and language. All these personal characteristics are observed in the administrative registers - except language, which I capture by country of origin dummies.

27 The probability of neighborhood relocation decreases with assignment to a socially deprived neighborhood, the log of the employment rate of non-Western immigrant men aged 18-60 living in the neighborhood of assignment and the log of the employment rate of co-national men aged 18-60 living in the neighborhood of assignment. These results suggest that refugee men derive high utility from living in a socially deprived neighborhood (which is partly explained by their preference for living close to other non-Western immigrants and access to large and high-quality public housing apartments) and close to employed non-Western immigrant men and co-national men.
} 
Table 4

Location assignment of individuals in the balanced panel of male refugees: Mean (standard deviation) of personal attributes in the year of assignment. Source: Administrative register data from Statistics Denmark.

\begin{tabular}{|c|c|c|c|}
\hline & \multicolumn{2}{|c|}{$\begin{array}{l}\text { Neighborhood of } \\
\text { assignment }\end{array}$} & \multirow[t]{2}{*}{$\begin{array}{l}t \text {-test of difference in } \\
\text { means }\end{array}$} \\
\hline & $\begin{array}{l}\text { Socially } \\
\text { deprived } \\
(1)\end{array}$ & $\begin{array}{l}\text { Non- } \\
\text { deprived } \\
(2)\end{array}$ & \\
\hline \multicolumn{4}{|l|}{ Years of education } \\
\hline $0-9$ years & $\begin{array}{l}0.126 \\
(0.33)\end{array}$ & $\begin{array}{l}0.119 \\
(0.32)\end{array}$ & 1.05 \\
\hline $10-12$ years & $\begin{array}{l}0.375 \\
(0.48)\end{array}$ & $\begin{array}{l}0.392 \\
(0.49)\end{array}$ & 1.59 \\
\hline At least 13 years & $\begin{array}{l}0.169 \\
(0.37)\end{array}$ & $\begin{array}{l}0.165 \\
(0.37)\end{array}$ & 0.42 \\
\hline Unknown education & $\begin{array}{l}0.330 \\
(0.47)\end{array}$ & $\begin{array}{l}0.324 \\
(0.47)\end{array}$ & 0.57 \\
\hline \multicolumn{4}{|l|}{$\begin{array}{l}\text { Other personal } \\
\text { characteristics }\end{array}$} \\
\hline Age & $\begin{array}{l}32.1 \\
(12.9)\end{array}$ & $\begin{array}{l}30.4 \\
(10.7)\end{array}$ & 6.54 \\
\hline Marital status & $\begin{array}{l}0.523 \\
(0.50)\end{array}$ & $\begin{array}{l}0.467 \\
(0.50)\end{array}$ & 5.15 \\
\hline Child aged $0-2$ & $\begin{array}{l}0.123 \\
(0.33)\end{array}$ & $\begin{array}{l}0.111 \\
(0.31)\end{array}$ & 1.66 \\
\hline Child aged 3-17 & $\begin{array}{l}0.231 \\
(0.42)\end{array}$ & $\begin{array}{l}0.179 \\
(0.38)\end{array}$ & 5.84 \\
\hline Number of observations & 2573 & 12,863 & \\
\hline
\end{tabular}

a socially deprived neighborhood increased the probability of staying in the neighborhood of assignment by 15.5 percentage points. Moreover, for neighborhood movers, assignment to a socially deprived neighborhood significantly increased the probability of moving to another socially deprived neighborhood. Further investigation shows that this effect is entirely driven by individuals who moved to another neighborhood within the municipality of assignment. For those individuals, assignment to a socially deprived neighborhood increased the probability of moving to another socially deprived neighborhood by 9.8 percentage points, controlling for individual characteristics. ${ }^{28} \mathrm{I}$, therefore, expect the indicator for assignment to a socially deprived neighborhood to be a strong predictor for current residence in a socially deprived neighborhood up to six years after assignment.

Summary statistics of the dependent variables for the overall balanced panel of male refugees and by treatment status are shown in Table 6. Six years after immigration, $30.6 \%$ of refugee men have a job and the average real annual earnings of refugee men with wage income were also very low, DKK 62,318 (in 2000-prices). ${ }^{29}$ Their poor labor market outcomes six years after immigration reflect that non-Western immigrants in general - and refugees in particular - have a very slow labor market assimilation process in Denmark (Husted et al., 2001; Damm and Rosholm, 2010).

\subsection{Two-stage least squares estimates of the effects of living in a socially deprived neighborhood}

In Table 7, Panel A, I report the linear regression estimates of living in a socially deprived neighborhood 2-6 years after immigration, using the specification in the main equation of Eq. (3), i.e. with individual-specific random effects. I report the estimates for two individual labor market outcomes: employment probability and real annual earnings. Moreover, I report the estimates for

\footnotetext{
28 These results are available upon request.

29 For comparison, in $2000,84 \%$ of men aged 20-59 in Denmark were employed (www.Statistikbanken.dk/RASA and BEF5) and their mean real annual earnings were DKK 238,294 (www.Statistikbanken.dk/INDKP1).
}

the overall sample as well as by skill group. Relative to the crosssection estimates of living in a socially deprived neighborhood using Eq. (2) (Table 2, Panel A), inclusion of individual-specific random effects decreases the magnitude of the estimates, but the coefficient estimates remain significant and negative.

Next, I estimate the effects of the policy of quasi-random assignment of refugees across socially deprived and non-deprived neighborhoods, using OLS and the same control set as in the main equation of Eq. (3). These intent-to-treat (ITT) estimates are reported in Panel B. According to the estimates, assignment to a socially deprived neighborhood has no significant effects on the employment probability and real annual earnings of refugees 26 years after assignment. ${ }^{30}$

Finally, in Panel C, I report the IV-estimates of living in a socially deprived neighborhood 2-6 years after immigration, from twostage least squares (2SLS) estimation of the IV-model in Eq. (3). Recall that the instrumental variable for current residence in a socially deprived neighborhood is an indicator which takes the value 1 if the neighborhood of assignment in the municipality of assignment was socially deprived in the year of assignment $t$ and 0 otherwise. The first stage regression estimates are also reported in Panel C. For the overall sample, ceteris paribus, assignment to a socially deprived neighborhood significantly increases the probability of living in a socially deprived neighborhood 2-6 years after immigration by $24.2 \%$. The $t$-statistic is 10 , corresponding to an $F$ statistic of 100 , hence the instrument is strong. Recall that the 2SLS estimate is defined as the ITT estimate (Panel $\mathrm{B}$ ) divided by the first-stage regression estimate (Panel $\mathrm{C}$ ). Therefore, the positive but insignificant ITT estimates translate into positive and insignificant 2SLS estimates of living in a socially deprived neighborhood 2-6 years after immigration on individual labor market outcomes (Panel C).

I interpret the insignificant 2SLS estimates of living in a socially deprived neighborhood as evidence that the negative and significant statistical associations between living in a socially deprived neighborhood and individual labor market outcomes (Table 7, Panel A, and Table 4) are entirely due to negative self-selection of individuals (e.g. individuals with poor host-country and/or English language skills) into socially deprived neighborhoods. Controlling for individual self-selection into neighborhoods, on average living in a socially deprived neighborhood does not affect individual labor market outcomes.

\subsection{Two-stage least squares estimates of continuous measures of neighborhood quality}

An obvious criticism of my findings in Section 3.5 is that the $60 \%$ employment rate threshold used to categorize neighborhoods as either socially deprived or non-deprived is somewhat arbitrary. Therefore, in Table 8, I report OLS and 2SLS estimates of alternative models of neighborhood job referral. In these models the bivariate explanatory variable "living in a socially deprived neighborhood" $\mathrm{D}_{j l(t+s)}$ in Eq. (3) is replaced by one of the three continuous variables of the quality of the neighborhood of residence in year $t+s$ : the log employment rate of men aged 18-60 (columns 1 and 4), the log mean years of education of men aged 18-60 (columns 2 and 5) and the log mean real annual earnings of men aged 18-60 (columns 3 and 6). As instrument for each of these continuous vari-

\footnotetext{
30 For comparison, I have estimated the average effect of assignment to a socially deprived neighborhood on labor market outcomes six years after assignment by applying PSM. Specifically, I have used nearest neighbor (1-1) matching with trimming and estimated the pscore by logit. According to the PSM estimates for the full sample and using the same control set as in Eq. (3), assignment to a socially deprived neighborhood has an insignificant effect on both the employment probability and real annual earnings six years after assignment. The PSM estimates are $0.005(0.020)$ in the employment model and $-0.143(0.126)$ in the earnings model.
} 
Table 5

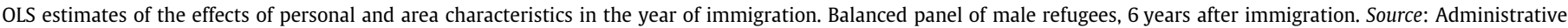
registers from Statistics Denmark.

\begin{tabular}{|c|c|c|c|c|c|c|c|}
\hline & \multicolumn{7}{|c|}{$\begin{array}{l}\text { Dependent variable } \\
\text { Having moved out of the neighborhood of assignment }\end{array}$} \\
\hline & $(1)$ & $(2)$ & $(3)$ & $(4)$ & $(5)$ & $(6)$ & $(7)$ \\
\hline \multicolumn{8}{|l|}{ Educational attainment (Ref. category: $0-9$ years of education) } \\
\hline $10-12$ years of education & $\begin{array}{l}-0.003 \\
(0.012)\end{array}$ & $\begin{array}{l}-0.003 \\
(0.011)\end{array}$ & $\begin{array}{l}-0.004 \\
(0.011)\end{array}$ & $\begin{array}{l}-0.004 \\
(0.011)\end{array}$ & $\begin{array}{l}-0.002 \\
(0.011)\end{array}$ & $\begin{array}{l}-0.003 \\
(0.012)\end{array}$ & $\begin{array}{l}-0.003 \\
(0.011)\end{array}$ \\
\hline More than 12 years of education & $\begin{array}{l}0.000 \\
(0.011)\end{array}$ & $\begin{array}{l}-0.002 \\
(0.010)\end{array}$ & $\begin{array}{l}-0.003 \\
(0.010)\end{array}$ & $\begin{array}{l}-0.003 \\
(0.010)\end{array}$ & $\begin{array}{l}0.001 \\
(0.010)\end{array}$ & $\begin{array}{l}-0.001 \\
(0.011)\end{array}$ & $\begin{array}{l}-0.002 \\
(0.010)\end{array}$ \\
\hline Unknown education & $\begin{array}{l}-0.007 \\
(0.013)\end{array}$ & $\begin{array}{l}-0.004 \\
(0.013)\end{array}$ & $\begin{array}{l}-0.005 \\
(0.013)\end{array}$ & $\begin{array}{l}-0.005 \\
(0.013)\end{array}$ & $\begin{array}{l}-0.006 \\
(0.013)\end{array}$ & $\begin{array}{l}-0.006 \\
(0.013)\end{array}$ & $\begin{array}{l}-0.004 \\
(0.013)\end{array}$ \\
\hline \multicolumn{8}{|l|}{ Other personal characteristics } \\
\hline Age & $\begin{array}{l}-0.004^{* *} \\
(0.000)\end{array}$ & $\begin{array}{l}-0.004^{* *} \\
(0.000)\end{array}$ & $\begin{array}{l}-0.004^{* *} \\
(0.000)\end{array}$ & $\begin{array}{l}-0.004^{* *} \\
(0.000)\end{array}$ & $\begin{array}{l}-0.004^{* *} \\
(0.000)\end{array}$ & $\begin{array}{l}-0.004^{* *} \\
(0.000)\end{array}$ & $\begin{array}{l}-0.004^{\text {*** }} \\
(0.000)\end{array}$ \\
\hline Married & $\begin{array}{l}-0.008 \\
(0.009)\end{array}$ & $\begin{array}{l}-0.008 \\
(0.008)\end{array}$ & $\begin{array}{l}-0.008 \\
(0.008)\end{array}$ & $\begin{array}{l}-0.008 \\
(0.008)\end{array}$ & $\begin{array}{l}-0.008 \\
(0.009)\end{array}$ & $\begin{array}{l}-0.009 \\
(0.008)\end{array}$ & $\begin{array}{l}-0.007 \\
(0.008)\end{array}$ \\
\hline Having a child aged $0-2$ & $\begin{array}{l}-0.060^{* *} \\
(0.012)\end{array}$ & $\begin{array}{l}-0.058^{* * *} \\
(0.011)\end{array}$ & $\begin{array}{l}-0.059^{* *} \\
(0.011)\end{array}$ & $\begin{array}{l}-0.059^{* *} \\
(0.011)\end{array}$ & $\begin{array}{l}-0.061 \\
(0.012)\end{array}$ & $\begin{array}{l}-0.059^{* *} \\
(0.012)\end{array}$ & $\begin{array}{l}-0.059^{* *} \\
(0.011)\end{array}$ \\
\hline Having a child aged $3-17$ & $\begin{array}{l}-0.082^{* *} \\
(0.015)\end{array}$ & $\begin{array}{l}-0.075^{* * *} \\
(0.015)\end{array}$ & $\begin{array}{l}-0.075^{* *} \\
(0.015)\end{array}$ & $\begin{array}{l}-0.075^{* *} \\
(0.014)\end{array}$ & $\begin{array}{l}-0.084^{* * *} \\
(0.015)\end{array}$ & $\begin{array}{l}-0.083^{* *} \\
(0.015)\end{array}$ & $\begin{array}{l}-0.077^{* *} \\
(0.014)\end{array}$ \\
\hline \multicolumn{8}{|l|}{ Neighborhood characteristics } \\
\hline Socially deprived neighborhood & - & $\begin{array}{l}-0.155^{* *} \\
(0.020)\end{array}$ & $\begin{array}{l}-0.123^{\text {** }} \\
(0.021)\end{array}$ & $\begin{array}{l}-0.123^{* *} \\
(0.021)\end{array}$ & - & - & $\begin{array}{l}-0.115^{* *} \\
(0.021)\end{array}$ \\
\hline Ln(pct. non-Western immigrant men aged 18-60) & - & - & $\begin{array}{l}-0.022^{* *} \\
(0.006)\end{array}$ & $\begin{array}{l}-0.023^{* *} \\
(0.006)\end{array}$ & - & - & $\begin{array}{l}-0.026^{\text {*** }} \\
(0.006)\end{array}$ \\
\hline Ln(pct. co-national men aged 18-60) & - & - & - & $\begin{array}{l}0.001 \\
(0.004)\end{array}$ & - & - & $\begin{array}{l}-0.002 \\
(0.005)\end{array}$ \\
\hline Ln(employment rate of non-Western immigrant men aged $18-60)$ & - & - & - & - & $\begin{array}{l}-0.004^{*} \\
(0.002)\end{array}$ & - & $\begin{array}{c}-0.004^{\dagger} \\
(0.002)\end{array}$ \\
\hline No other non-Western immigrant men aged 18-60 & - & - & - & - & $\begin{array}{l}-0.117^{* *} \\
(0.043)\end{array}$ & - & $\begin{array}{l}-0.126^{* *} \\
(0.042)\end{array}$ \\
\hline Ln(employment rate of co-national men aged 18-60) & - & - & - & - & - & $\begin{array}{l}-0.006^{* *} \\
(0.001)\end{array}$ & $\begin{array}{l}-0.004^{* *} \\
(0.001)\end{array}$ \\
\hline No co-national men aged $18-60$ & - & - & - & - & - & $\begin{array}{l}0.012 \\
(0.012)\end{array}$ & $\begin{array}{l}-0.004 \\
(0.012)\end{array}$ \\
\hline $\begin{array}{l}\mathrm{R}^{2} \\
\text { Number of observations }\end{array}$ & $\begin{array}{l}0.075 \\
15,436\end{array}$ & 0.098 & 0.100 & 0.100 & 0.081 & 0.078 & 0.110 \\
\hline
\end{tabular}

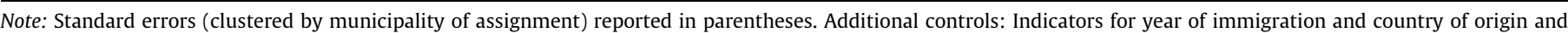

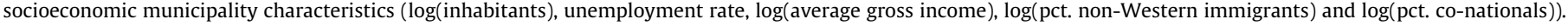
Values of control variables are measured in the year of assignment.

$+P<0.1$.

$P<0.05$.

** $P<0.01$.

ables of neighborhood quality I use the corresponding measure of neighborhood quality for the assigned neighborhood in the year $t$. The balancing tests reported in Table A5, Part A, columns 2-4, support the assumption of validity of these instruments.

As shown in Panel C, with the exception of one specification, the instruments are strong. For instance, a log increase in the employment rate of men aged 18-60 living in the neighborhood of assignment increases the log of the employment rate of men aged 18-60 in the neighborhood of residence 2-6 years after assignment by 0.309 ( $t$-statistic of 8.2, corresponding to an F-statistic of 67) in the employment model 2 and by 0.236 ( $t$-statistic of 8.6, corresponding to an F-statistic of 74) in the earnings model.

However, as shown in Panel B, the ITT estimates are close to zero and insignificant for all specifications. Therefore, the insignificance of the ITT estimates translates into insignificant 2SLS estimates (Panel C) across all specifications. That is, taking account of neighborhood selection, labor market outcomes of refugee men 2-6 years after immigration are not affected by the quality of the neighborhood of residence $2-6$ years after immigration. This finding is robust to whether I measure neighborhood quality in terms of the employment rate, mean years of education or mean real annual earnings of men aged 18-60. Separate estimations for each skill group of the effects of each of these three continuous measures of neighborhood quality also yield insignificant 2SLS estimates. $^{31}$

Based on my findings of insignificant 2SLS estimates reported in Panel C, I conclude that the positive and significant correlations between each of the three continuous measures of neighborhood quality and individual labor market outcomes 2-6 years after immigration (Panel A) are entirely due to positive individual selfselection into high-quality neighborhoods. Moreover, from the insignificant 2SLS estimates reported in Tables 7 and 8 I conclude that the overall quality of the neighborhood has insignificant effects on individual labor market outcomes. I now turn to estimation of alternative models of neighborhood effects.

\section{Ethnic stratification of networks}

Recall from Section 2 that 26.3\% of immigrants in the Welfare Research Survey had found their latest (wage earner) job through their social network. Table 1, Panel C, shows that $74.7 \%$ (87.2\% of low-skilled) of immigrant survey respondents who found their latest job through their social network found it through other immi-

\footnotetext{
31 These results are available upon request.
} 
Table 6

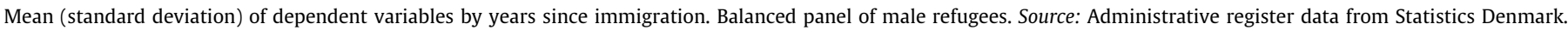

\begin{tabular}{|c|c|c|c|c|c|c|}
\hline \multirow[t]{3}{*}{ Years since immigration } & \multicolumn{6}{|c|}{ Dependent variable } \\
\hline & \multicolumn{3}{|c|}{$\begin{array}{l}\text { Employed in November } \\
\text { Neighborhood of assignment }\end{array}$} & \multicolumn{3}{|c|}{ Ln(real annual earnings) } \\
\hline & $\begin{array}{l}\text { All } \\
(1)\end{array}$ & $\begin{array}{l}\text { Socially deprived } \\
(2)\end{array}$ & $\begin{array}{l}\text { Non-deprived } \\
(3)\end{array}$ & $\begin{array}{l}\text { All } \\
(4)\end{array}$ & $\begin{array}{l}\text { Socially deprived } \\
(5)\end{array}$ & $\begin{array}{l}\text { Non-deprived } \\
(6)\end{array}$ \\
\hline 1 & $\begin{array}{l}0.049 \\
(0.215)\end{array}$ & $\begin{array}{l}0.036 \\
(0.187)\end{array}$ & $\begin{array}{l}0.051 \\
(0.22)\end{array}$ & $\begin{array}{l}9.64 \\
(1.7)\end{array}$ & $\begin{array}{l}9.48 \\
(1.81)\end{array}$ & $\begin{array}{l}9.66 \\
(1.68)\end{array}$ \\
\hline $\mathrm{N}$ & 15,436 & 2573 & 12,863 & 1556 & 197 & 1359 \\
\hline 2 & $\begin{array}{l}0.121 \\
(0.326)\end{array}$ & $\begin{array}{l}0.091 \\
(0.288)\end{array}$ & $\begin{array}{l}0.127 \\
(0.333)\end{array}$ & $\begin{array}{l}10.36 \\
(1.54)\end{array}$ & $\begin{array}{l}10.21 \\
(1.63)\end{array}$ & $\begin{array}{l}10.38 \\
(1.53)\end{array}$ \\
\hline $\mathrm{N}$ & 15,436 & 2573 & 12,863 & 3321 & 412 & 2909 \\
\hline 3 & $\begin{array}{l}0.19 \\
(0.393)\end{array}$ & $\begin{array}{l}0.158 \\
(0.365)\end{array}$ & $\begin{array}{l}0.197 \\
(0.398)\end{array}$ & $\begin{array}{l}10.66 \\
(1.53)\end{array}$ & $\begin{array}{l}10.47 \\
(1.61)\end{array}$ & $\begin{array}{l}10.69 \\
(1.52)\end{array}$ \\
\hline $\mathrm{N}$ & 15,436 & 2573 & 12,863 & 4605 & 638 & 3967 \\
\hline 4 & $\begin{array}{l}0.239 \\
(0.427)\end{array}$ & $\begin{array}{l}0.207 \\
(0.405)\end{array}$ & $\begin{array}{l}0.245 \\
(0.43)\end{array}$ & $\begin{array}{l}10.85 \\
(1.51)\end{array}$ & $\begin{array}{l}10.8 \\
(1.55)\end{array}$ & $\begin{array}{l}10.85 \\
(1.51)\end{array}$ \\
\hline $\mathrm{N}$ & 15,436 & 2573 & 12,863 & 5177 & 717 & 4460 \\
\hline 5 & $\begin{array}{l}0.274 \\
(0.446)\end{array}$ & $\begin{array}{l}0.259 \\
(0.438)\end{array}$ & $\begin{array}{l}0.277 \\
(0.447)\end{array}$ & $\begin{array}{l}10.93 \\
(1.50)\end{array}$ & $\begin{array}{l}10.91 \\
(1.62)\end{array}$ & $\begin{array}{l}10.93 \\
(1.48)\end{array}$ \\
\hline $\mathrm{N}$ & 15,436 & 2573 & 12,863 & 5646 & 821 & 4825 \\
\hline 6 & $\begin{array}{l}0.306 \\
(0.461)\end{array}$ & $\begin{array}{l}0.288 \\
(0.453)\end{array}$ & $\begin{array}{l}0.31 \\
(0.463)\end{array}$ & $\begin{array}{l}11.04 \\
(1.46)\end{array}$ & $\begin{array}{l}11 \\
(1.50)\end{array}$ & $\begin{array}{l}11.05 \\
(1.45)\end{array}$ \\
\hline $\mathrm{N}$ & 15,436 & 2573 & 12,863 & 5976 & 889 & 5087 \\
\hline
\end{tabular}

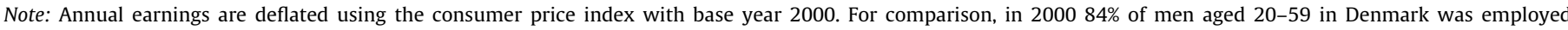

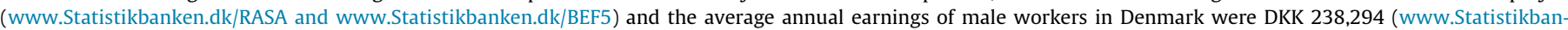
ken.dk/INDKP1).

Table 7

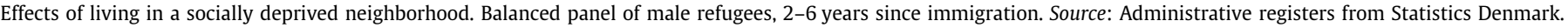

\begin{tabular}{|c|c|c|c|c|c|c|}
\hline & \multicolumn{6}{|c|}{ Dependent variable } \\
\hline & \multicolumn{3}{|c|}{ Employed in November } & \multicolumn{3}{|c|}{ Ln(real annual earnings) } \\
\hline & $\begin{array}{l}\text { All } \\
(1)\end{array}$ & $\begin{array}{l}\text { Low-skilled } \\
\text { (2) }\end{array}$ & $\begin{array}{l}\text { Highly skilled } \\
\text { (3) }\end{array}$ & $\begin{array}{l}\text { All } \\
(4)\end{array}$ & $\begin{array}{l}\text { Low-skilled } \\
\text { (5) }\end{array}$ & $\begin{array}{l}\text { Highly skilled } \\
(6)\end{array}$ \\
\hline $\begin{array}{l}\text { Panel A: OLS estimates } \\
\text { Current residence in a socially deprived neighborhood }\end{array}$ & $\begin{array}{l}-0.027^{* *} \\
(0.003)\end{array}$ & $\begin{array}{l}-0.016^{* *} \\
(0.004)\end{array}$ & $\begin{array}{l}-0.034^{* *} \\
(0.005)\end{array}$ & $\begin{array}{l}-0.062^{*} \\
(0.028)\end{array}$ & $\begin{array}{l}-0.011 \\
(0.034)\end{array}$ & $\begin{array}{l}-0.102^{* *} \\
(0.038)\end{array}$ \\
\hline $\begin{array}{l}\text { Panel B: Intent-to-treat estimates (OLS) } \\
\text { Assigned to a socially deprived neighborhood }\end{array}$ & $\begin{array}{l}0.009 \\
(0.005)\end{array}$ & $\begin{array}{l}0.005 \\
(0.012)\end{array}$ & $\begin{array}{l}0.011 \\
(0.006)\end{array}$ & $\begin{array}{l}0.075 \\
(0.040)\end{array}$ & $\begin{array}{l}0.022 \\
(0.063)\end{array}$ & $\begin{array}{l}0.108^{*} \\
(0.046)\end{array}$ \\
\hline $\begin{array}{l}\text { Panel C: } 2 S L S \text { estimates } \\
\text { Current residence in a socially deprived neighborhood }\end{array}$ & $\begin{array}{l}0.039 \\
(0.028)\end{array}$ & $\begin{array}{l}0.021 \\
(0.038)\end{array}$ & $\begin{array}{l}0.047 \\
(0.040)\end{array}$ & $\begin{array}{l}0.354 \\
(0.216)\end{array}$ & $\begin{array}{l}0.102 \\
(0.351)\end{array}$ & $\begin{array}{l}0.474 \\
(0.272)\end{array}$ \\
\hline $\begin{array}{l}\text { First stage of } 2 S L S(O L S) \\
\text { Assignment to a socially deprived neighborhood }\end{array}$ & $\begin{array}{l}0.242^{* *} \\
(0.024)\end{array}$ & $\begin{array}{l}0.247^{* * *} \\
(0.026)\end{array}$ & $\begin{array}{l}0.237^{* *} \\
(0.025)\end{array}$ & $\begin{array}{l}0.210^{* *} \\
(0.026)\end{array}$ & $\begin{array}{l}0.185^{* *} \\
(0.036)\end{array}$ & $\begin{array}{l}0.231^{* * *} \\
(0.029)\end{array}$ \\
\hline $\begin{array}{l}\text { Number of observations } \\
\text { Number of individuals }\end{array}$ & $\begin{array}{l}77,180 \\
15,436\end{array}$ & $\begin{array}{l}34,360 \\
6,872\end{array}$ & $\begin{array}{l}42,820 \\
8,564\end{array}$ & $\begin{array}{l}24,725 \\
8,864\end{array}$ & $\begin{array}{l}10,595 \\
3,849\end{array}$ & $\begin{array}{l}14,130 \\
5,015\end{array}$ \\
\hline
\end{tabular}

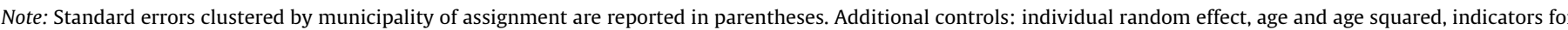

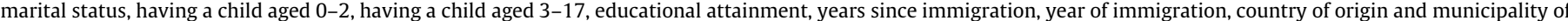

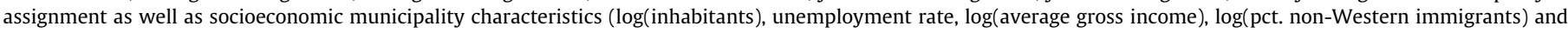

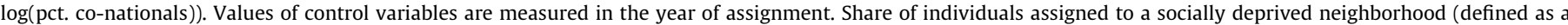
neighborhood in which at most $60 \%$ of individuals aged 18-60 are employed): 0.167 .

** $P<0.01$.

${ }^{*} P<0.05$.

grants. This descriptive evidence suggests that immigrants' job search networks are ethnically stratified. ${ }^{32}$ Therefore, residencebased job search networks may also be ethnically stratified. I inves-

\footnotetext{
32 Note that the descriptive evidence does not imply that immigrant contacts are necessarily a more productive source of referral. It could simply be that referrals predominantly come from immigrants because immigrants are overrepresented in an immigrant's network. However, only $27 \%$ of immigrant respondents in the Welfare Research Survey answer that the majority of their acquaintances are foreign-born.
}

tigate this hypothesis in this section using two alternative definitions of ethnically stratified residence-based networks.

\subsection{Two-stage least squares estimates of the effects of immigrant residence-based networks}

If immigrants primarily know other immigrants, the quality of the non-Western immigrant network in the neighborhood would be a better measure of residence-based contacts of refugee men 
Table 8

Effects of the quality of neighbors. Balanced panel of male refugees, 2-6 years since immigration. Source: Administrative registers from Statistics Denmark.

\begin{tabular}{|c|c|c|c|c|c|c|}
\hline & \multicolumn{6}{|c|}{ Dependent variable } \\
\hline & \multicolumn{3}{|c|}{ Employed in November } & \multicolumn{3}{|c|}{ Ln(real annual earnings) } \\
\hline & (1) & $(2)$ & $(3)$ & $(4)$ & $(5)$ & $(6)$ \\
\hline \multicolumn{7}{|l|}{ Panel A: OLS estimates of characteristics of current neighborhood of residence } \\
\hline Ln(employment rate of men aged $18-60)$ & $\begin{array}{l}0.087^{* *} \\
(0.008)\end{array}$ & - & - & $\begin{array}{l}0.310^{* * *} \\
(0.075)\end{array}$ & - & - \\
\hline $\operatorname{Ln}($ mean years of education of men aged $18-60)$ & - & $\begin{array}{l}0.008^{* *} \\
(0.001)\end{array}$ & - & - & $\begin{array}{l}0.033^{*} \\
(0.015)\end{array}$ & - \\
\hline $\operatorname{Ln}($ mean real annual earnings of men aged $18-60)$ & - & - & $\begin{array}{l}0.004^{* *} \\
(0.000)\end{array}$ & - & - & $\begin{array}{l}0.016^{*} \\
(0.007)\end{array}$ \\
\hline \multicolumn{7}{|l|}{ Panel B: Intent-to-treat estimates (OLS estimates of characteristics of neighborhood of assignment) } \\
\hline Ln(employment rate of men aged $18-60)$ & $\begin{array}{l}-0.002 \\
(0.012)\end{array}$ & - & - & $\begin{array}{l}-0.092 \\
(0.102)\end{array}$ & - & - \\
\hline $\operatorname{Ln}($ mean years of education of men aged $18-60)$ & - & $\begin{array}{l}0.065 \\
(0.034)\end{array}$ & - & - & $\begin{array}{l}0.300 \\
(0.342)\end{array}$ & - \\
\hline $\operatorname{Ln}($ mean real annual earnings of men aged $18-60)$ & - & - & $\begin{array}{l}0.001 \\
(0.009)\end{array}$ & - & - & $\begin{array}{l}-0.043 \\
(0.068)\end{array}$ \\
\hline \multicolumn{7}{|l|}{ Panel C: 2SLS estimates of characteristics of current neighborhood of residence } \\
\hline $\operatorname{Ln}($ employment rate of men aged $18-60)$ & $\begin{array}{l}-0.007 \\
(0.047)\end{array}$ & - & - & $\begin{array}{l}-0.390 \\
(0.420)\end{array}$ & - & - \\
\hline $\operatorname{Ln}($ mean years of education of men aged $18-60)$ & - & $\begin{array}{l}0.415 \\
(0.402)\end{array}$ & - & - & $\begin{array}{l}1.655 \\
(2.141)\end{array}$ & - \\
\hline $\operatorname{Ln}($ mean real annual earnings of men aged $18-60)$ & - & - & $\begin{array}{l}0.006 \\
(0.039)\end{array}$ & - & - & $\begin{array}{c}-0.176 \\
(0.262)\end{array}$ \\
\hline \multicolumn{7}{|l|}{ First stage of $2 S L S$} \\
\hline $\begin{array}{l}\text { Effects on } \ln \text { (employment rate of men living in current neighborhood of residence) of } \\
\text { Ln(employment rate of men aged 18-60 living in neighbourhood of assignment) }\end{array}$ & $\begin{array}{l}0.309^{* *} \\
(0.038)\end{array}$ & - & - & $\begin{array}{l}0.236^{* *} \\
(0.027)\end{array}$ & - & - \\
\hline $\begin{array}{l}\text { Effects on } \ln \text { (mean years of education of men living in current neighborhood of residence) of } \\
\operatorname{Ln}(\text { mean years of education of men aged 18-60 living in neighbourhood of assignment) }\end{array}$ & - & $\begin{array}{l}0.157^{* *} \\
(0.059)\end{array}$ & - & - & $\begin{array}{l}0.181 \\
(0.142)\end{array}$ & - \\
\hline $\begin{array}{l}\text { Effects on } \ln \text { (mean real annual earnings of men living in current neighborhood of residence) of } \\
\text { Ln(mean real annual earnings of men aged 18-60 living in neighbourhood of assignment) }\end{array}$ & - & - & $\begin{array}{l}0.233^{* *} \\
(0.042)\end{array}$ & - & - & $\begin{array}{l}0.251^{* *} \\
(0.081)\end{array}$ \\
\hline Number of observations & 77,180 & & & 24,725 & & \\
\hline Number of individuals & 15,436 & & & 8864 & & \\
\hline
\end{tabular}

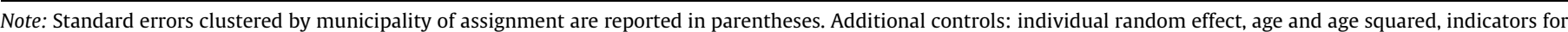

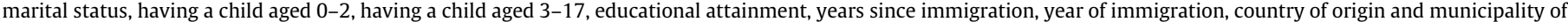

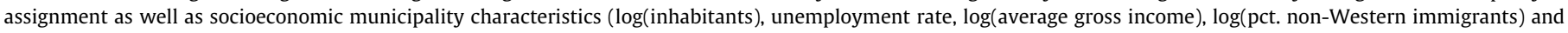
$\log$ (pct. co-nationals)). Values of control variables are measured in the year of assignment.

** $P<0.01$.

$P<0.05$.

than the overall quality. Therefore, I estimate the IV-model in Eq. (3), except that I replace the indicator for current residence in a socially deprived neighborhood $\mathrm{D}_{j l(t+s)}$ by one of two measures of the quality of non-Western immigrant male contacts in the neighborhood: $\log$ employment rate and log mean years of education - of non-Western immigrant men aged 18-60 living in the neighborhood of residence 2-6 years after immigration. As instruments for each of these two variables, I use the corresponding measure of the quality of non-Western immigrant contacts living the assigned neighborhood in the year $t$ and an indicator for zero nonWestern immigrant men aged 18-60 living in the neighborhood of assignment in year $t$. The balancing tests for individuals in the balanced panel of male refugees reported in Table A5, Part A, columns 6-9, provide evidence for the validity of these instruments; refugees with different skill levels appear to have been randomly assigned to neighborhoods with varying quality and presence of non-Western immigrant men, conditional on the personal characteristics known by the council.

I report the 2SLS estimates and the first stage regression estimates in Table 9, Panel C, (columns 1, 2, 6 and 7). The instruments for log employment rate of non-Western immigrant men aged 1860 living in the neighborhood of residence 2-6 years after immigration enter the first stage regression with the expected signs and, with F-statistics for joint insignificance of the exclusion restrictions of 113 (column 1) and 37 (column 6), they are strong predictors. The instruments for the log mean years of education of non-Western immigrant men aged 18-60 living in the neighborhood of residence 2-6 years after immigration are strong ( $F$-stat of 62 ) in the employment model (column 2), but weak (F-stat well below 10) in the earnings model (column 7 ). Therefore, one should interpret the 2SLS estimate in column 7 with caution.

According to the 2SLS estimates in columns 1 and 6, the log employment rate of non-Western immigrant men aged 18-60 living in the neighborhood of residence has a positive and significant effect on the individual's employment probability as well as on real annual earnings. Around the sample mean of $38.6 \%$, a ten percentage points increase in the employment rate of non-Western immigrant men aged 18-60 living in the neighborhood of residence corresponds to 0.23 of a log increase. This implies that, on average, a ten percentage points increase in the employment rate of nonWestern immigrant men aged 18-60 living in the neighborhood of residence (around the mean) increases the individual's employment probability by $(0.23 * 0.065=) 1.5$ percentage points and log real annual earnings by $(0.23 * 0.808=) 0.19$, corresponding to a $20 \%$ increase in real annual earnings $2-6$ years after immigration.

The log mean years of education of non-Western immigrant men age 18-60 living in the neighborhood of residence also has a positive and significant effect on the individual's employment probability, while its effect on individual real annual earnings is positive but insignificant, possibly because of the weak instru- 


\begin{tabular}{|c|c|c|c|c|c|c|c|c|c|c|}
\hline & \multicolumn{5}{|c|}{ Dependent variable: Employed in November } & \multicolumn{5}{|c|}{ Dependent variable: $\operatorname{Ln}($ real annual earnings) } \\
\hline & (1) & $(2)$ & (3) & (4) & (5) & (6) & (7) & $(8)$ & (9) & (10) \\
\hline $\begin{array}{l}\text { Panel A: OLS estimates of characteristics of current neighborhood of residence } \\
\mathrm{Ln}(\text { employment rate of non-Western immigrant men aged 18-60) }\end{array}$ & $\begin{array}{l}0.010^{* *} \\
(0.002)\end{array}$ & - & $\begin{array}{l}0.011^{* *} \\
(0.002)\end{array}$ & - & $\begin{array}{l}0.010^{* *} \\
(0.002)\end{array}$ & $\begin{array}{l}0.053^{* *} \\
(0.011)\end{array}$ & - & $\begin{array}{l}0.054^{* *} \\
(0.011)\end{array}$ & - & $\begin{array}{l}0.052^{* *} \\
(0.010)\end{array}$ \\
\hline $\operatorname{Ln}($ mean years of education of non-Western immigrant men aged $18-60$ ) & - & $\begin{array}{l}0.007^{* *} \\
(0.001)\end{array}$ & - & $\begin{array}{l}0.008^{* *} \\
(0.001)\end{array}$ & $\begin{array}{l}0.007^{* *} \\
(0.001)\end{array}$ & - & $\begin{array}{l}0.026^{\dagger} \\
(0.015)\end{array}$ & - & $\begin{array}{l}0.029^{*} \\
(0.015)\end{array}$ & $\begin{array}{l}0.023 \\
(0.015)\end{array}$ \\
\hline Ln(pct. non-Western immigrant men aged 18-60) & - & - & $\begin{array}{l}-0.014^{* *} \\
(0.002)\end{array}$ & $\begin{array}{l}-0.014^{* *} \\
(0.002)\end{array}$ & - & - & - & $\begin{array}{l}-0.042^{* *} \\
(0.011)\end{array}$ & $\begin{array}{l}-0.042^{* *} \\
(0.011)\end{array}$ & - \\
\hline \multicolumn{11}{|l|}{ Panel B: 2SLS estimates of characteristics of current neighborhood of residence } \\
\hline Ln(employment rate of non-Western immigrant men aged 18-60) & $\begin{array}{l}0.065^{\dagger} \\
(0.039)\end{array}$ & - & $\begin{array}{l}0.071^{\dagger} \\
(0.039)\end{array}$ & - & $\begin{array}{l}0.034 \\
(0.044)\end{array}$ & $\begin{array}{l}0.808^{* *} \\
(0.295)\end{array}$ & - & $\begin{array}{l}0.815^{* *} \\
(0.296)\end{array}$ & - & $\begin{array}{l}0.703^{*} \\
(0.326)\end{array}$ \\
\hline $\operatorname{Ln}($ mean years of education of non-Western immigrant men aged $18-60$ ) & - & $\begin{array}{l}0.142^{*} \\
(0.058)\end{array}$ & - & $\begin{array}{l}0.147^{*} \\
(0.058)\end{array}$ & $\begin{array}{l}0.117^{+} \\
(0.063)\end{array}$ & - & $\begin{array}{l}3.015 \\
(3.111)\end{array}$ & - & $\begin{array}{l}2.949 \\
(2.933)\end{array}$ & $\begin{array}{l}0.869 \\
(1.169)\end{array}$ \\
\hline Ln(pct. non-Western immigrant men aged 18-60) & - & - & $\begin{array}{l}-0.025^{*} \\
(0.013)\end{array}$ & $\begin{array}{l}-0.023^{\dagger} \\
(0.013)\end{array}$ & - & - & - & $\begin{array}{l}-0.135 \\
(0.118)\end{array}$ & $\begin{array}{l}0.047 \\
(0.367)\end{array}$ & - \\
\hline \multicolumn{11}{|l|}{$\begin{array}{l}\text { Effects on In(employment rate of non-Western immigrant men aged 18-60 living in } \\
\text { current neighborhood of residence) }\end{array}$} \\
\hline $\begin{array}{l}\text { Ln(employment rate of non-Western immigrant men aged 18-60 living in } \\
\text { assigned neighborh.) }\end{array}$ & $\begin{array}{l}0.031^{* *} \\
(0.005)\end{array}$ & - & $\begin{array}{l}0.031^{* *} \\
(0.005)\end{array}$ & - & $\begin{array}{l}0.029^{* *} \\
(0.005)\end{array}$ & $\begin{array}{l}0.028^{* *} \\
(0.005)\end{array}$ & - & $\begin{array}{l}0.028^{* *} \\
(0.005)\end{array}$ & - & $\begin{array}{l}0.024^{* *} \\
(0.006)\end{array}$ \\
\hline No other non-Western immigrant men aged $18-60$ in assigned neighborhood & $\begin{array}{l}-0.156^{* *} \\
(0.048)\end{array}$ & - & $\begin{array}{l}-0.155^{* *} \\
(0.048)\end{array}$ & - & $\begin{array}{l}-0.048 \\
(0.092)\end{array}$ & $\begin{array}{l}-0.166^{* *} \\
(0.055)\end{array}$ & - & $\begin{array}{l}-0.163^{* *} \\
(0.055)\end{array}$ & - & $\begin{array}{l}-0.020 \\
(0.099)\end{array}$ \\
\hline F-test of joint insignificance of the exclusion restrictions & $\begin{array}{l}\mathrm{F}(2,76897) \\
113^{* *}\end{array}$ & - & $\begin{array}{l}F(3,76896) \\
76^{* *}\end{array}$ & - & $\begin{array}{l}F(3,76896) \\
80^{* *}\end{array}$ & $\begin{array}{l}\mathrm{F}(2,24454) \\
37^{* *}\end{array}$ & - & $\begin{array}{l}F(3,24453) \\
25^{* *}\end{array}$ & - & $\begin{array}{l}\mathrm{F}(3,24453) \\
28^{* *}\end{array}$ \\
\hline \multicolumn{11}{|l|}{$\begin{array}{l}\text { Effects on } \ln \text { (mean years of education of non-Western immigrant men aged 18-60 } \\
\text { living in current neighborhood of residence) }\end{array}$} \\
\hline $\begin{array}{l}\text { Ln(mean years of education of non-Western immigrant men aged 18-60 in } \\
\text { assigned neighborh.) }\end{array}$ & - & $\begin{array}{l}0.013^{* *} \\
(0.005)\end{array}$ & - & $\begin{array}{l}0.013^{* *} \\
(0.005)\end{array}$ & $\begin{array}{l}0.014^{* *} \\
(0.005)\end{array}$ & - & $\begin{array}{l}0.008 \\
(0.008)\end{array}$ & - & $\begin{array}{l}0.008 \\
(0.008)\end{array}$ & $\begin{array}{l}0.011 \\
(0.008)\end{array}$ \\
\hline No other non-Western immigrant men aged $18-60$ in assigned neighborhood & - & $\begin{array}{l}-0.110^{\dagger} \\
(0.057)\end{array}$ & - & $\begin{array}{l}-0.110^{\dagger} \\
(0.057)\end{array}$ & $\begin{array}{l}-0.099^{*} \\
(0.057)\end{array}$ & - & $\begin{array}{l}-0.006 \\
(0.081)\end{array}$ & - & $\begin{array}{l}-0.110^{\dagger} \\
(0.057)\end{array}$ & $\begin{array}{l}0.015 \\
(0.082)\end{array}$ \\
\hline F-test of joint significance of the exclusion restrictions & - & $\begin{array}{l}\mathrm{F}(2,76897) \\
62^{* *}\end{array}$ & - & $\begin{array}{l}\mathrm{F}(2,76897) \\
62^{* *}\end{array}$ & $\begin{array}{l}F(3,76896) \\
42^{* *}\end{array}$ & - & $\begin{array}{l}\mathrm{F}(2,24454) \\
3^{*}\end{array}$ & - & $\begin{array}{l}\mathrm{F}(2,24454) \\
3^{*}\end{array}$ & $\begin{array}{l}\mathrm{F}(3,24453) \\
3^{*}\end{array}$ \\
\hline \multicolumn{11}{|l|}{$\begin{array}{l}\text { Effects on } \ln (\text { pct. non-Western immigrant men aged 18-60 living in neighborhood } \\
\text { of residence) }\end{array}$} \\
\hline Ln(pct. non-Western immigrant men aged $18-60$ in assigned neighborhood) & - & - & $\begin{array}{l}0.202^{* *} \\
(0.024)\end{array}$ & $\begin{array}{l}0.202^{* *} \\
(0.024)\end{array}$ & - & - & - & $\begin{array}{l}0.165^{* *} \\
(0.018)\end{array}$ & $\begin{array}{l}0.165^{* *} \\
(0.018)\end{array}$ & - \\
\hline F-test of joint insignificance of the exclusion restrictions & - & - & $\begin{array}{l}\mathrm{F}(3,76896) \\
723^{* *}\end{array}$ & $\begin{array}{l}\mathrm{F}(3,76896) \\
723^{* *}\end{array}$ & - & - & - & $\begin{array}{l}\mathrm{F}(3,24453) \\
158^{* *}\end{array}$ & $\begin{array}{l}\mathrm{F}(3,24453) \\
158^{* *}\end{array}$ & - \\
\hline Number of observations & 77,180 & & & & & 24,725 & & & & \\
\hline Number of individuals & 15,436 & & & & & 8864 & & & & \\
\hline
\end{tabular}

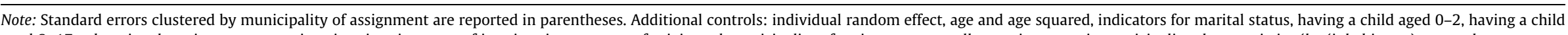

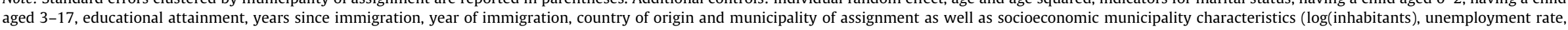
$\log$ (average gross income), $\log$ (pct. non-Western immigrants) and $\log ($ pct. co-nationals)). Values of control variables are measured in the year of assignment.

* $P<0.01$.

$* \quad P<0.05$.
$+\quad P<0.1$. 
ments (Table 9, Panel C, columns 2 and 7). Around the sample mean of 8.2 years, a one-year increase in the mean years of education of non-Western immigrant men aged 18-60 living in the neighborhood of residence corresponds to 0.12 of a log increase. This means that, on average, having non-Western immigrant male neighbors whose mean years of education is one year above the average, increases the individual's employment probability by $(0.12 * 0.142=) 1.6$ percentage points. ${ }^{33}$ Separate 2 SLS-estimations for each skill group of the separate effect of the two quality measures of the non-Western immigrant male neighbors show no skill group differences. $^{34}$

As seen from the 2SLS estimates reported in Table 9, Panel B, columns $3,4,8$ and 9 , these sets of results are robust to inclusion of the size of the non-Western immigrant network in the neighborhood as an additional explanatory variable. I measure this network size by the log percentage non-Western immigrant men aged 1860 living in the neighborhood of residence 2-6 years after immigration and instrument it by the log percentage non-Western immigrant men aged 18-60 living in the assigned neighborhood in the year of assignment. ${ }^{35}$

In the final specification reported in Table 9, columns 5 and 10, I include both measures of the quality of the non-Western immigrant neighbors: the log employment rate and the log mean years of education of non-Western immigrant men aged 18-60 living in the neighborhood of residence 2-6 years after immigration. According to the 2SLS estimates, both measures have a positive effect on the individual's employment probability; however, the effect of log employment rate of non-Western immigrant men turns insignificant. Due to the weak instruments for the log mean years of education of non-Western immigrant men in the earnings model, one should interpret the 2SLS estimates in column 10 with caution.

\subsection{Two-stage least squares estimates of the effects of co-ethnic residence-based networks}

The results in Table 9 provide strong evidence of neighborhood effects, in particular that non-Western immigrant men in part find jobs through employed and relatively highly educated contacts of non-Western immigrant origin living in the neighborhood of residence. But are all employed contacts of non-Western immigrant origin in the neighborhood equally useful for finding a (well-paid) job? Or are employed contacts from the individual's own source country (henceforth referred to as co-nationals) particularly valuable?

I investigate this question by estimating the 2SLS estimate of (i) the log employment rate of co-national men aged 18-60 living in the neighborhood of residence and (ii) the log mean years of edu-

\footnotetext{
33 Similarly, the 2SLS estimate of the third measure of the quality of non-Western immigrant male neighbors, the log mean real annual earnings of non-Western immigrant men aged 18-60 living in the neighborhood of residence 2-6 years after immigration is positive and significant, when I instrument it by the log mean real annual earnings of non-Western immigrant men aged 18-60 living in the assigned neighborhood in the year of assignment. The instrument is strong. However, the 2SLS estimate approaches zero in both models (and even turns negative in the employment model) when I include one of the two other measures of the quality of non-Western immigrant male neighbors as an additional explanatory variable.

34 The results are available upon request.

35 In column 3 I report a negative and significant 2SLS estimate of the log percentage non-Western immigrant men aged 18-60 living in the neighborhood of residence 2-6 years after immigration on the individual's employment probability. However, the estimate turns insignificant after inclusion of an interaction term between the log employment rate of non-Western immigrant men in the neighborhood and the log percentage non-Western immigrant men in the neighborhood. As instrument for the interaction term I use the interaction between the log employment rate of nonWestern immigrant men aged 18-60 living in the neighborhood of assignment in the year of assignment and the log percentage non-Western immigrant men aged 18-60 living in the neighborhood of assignment in the year of assignment. The instrument is strong in both the employment and earnings models.
}

cation of co-national men aged 18-60 living in the neighborhood of residence. As before I use the IV-model in Eq. (3), except that I now replace the indicator for current residence in a socially deprived neighborhood, $\mathrm{D}_{j l(t+s) \text {, by one of the before-mentioned measures }}$ of the quality of the co-national group in the neighborhood. In each case, I instrument the quality of the co-national group in the current neighborhood by the corresponding measure of the quality of the co-national group in the assigned neighborhood in year $t$ and an indicator for no other co-national men aged 18-60 living in the assigned neighborhood in year $t$. The balancing tests in Table A5, Part B, columns 1-5, support the assumption of validity of these instruments: refugees with different skill levels appear to have been randomly assigned to neighborhoods with varying quality and presence of co-national men, conditional on the personal characteristics known by the council.

Table 10, Panel B, columns 1-2 (employment model) and 5-6 (earnings model), shows the 2SLS estimates of the two measures of the quality of the co-national group in the neighborhood; firststage regression estimates are reported in Panel C. With F-statistics of 85 and 13 for joint insignificance of the exclusion restrictions, the instruments for the log employment rate of co-national men aged 18-60 living in the neighborhood of residence 2-6 years after immigration are found to be strong in both models. Turning to the instruments for the log mean years of education of co-national men in neighborhood, they are strong in the employment model (F-statistic of 37), but weak in the earnings model (F-statistic of 9 ). According to the 2SLS estimates, an increase in the employment rate of co-national men aged 18-60 living in the neighborhood significantly raises individual real annual earnings; the effect on the individual's employment probability is also positive but insignificantly so. A ten percentage points increase in the employment rate of co-national men aged 18-60 living in the neighborhood 26 years after immigration (around the sample mean of 23.2\%) corresponds to a $\log$ increase of 0.36 and therefore raises log real annual earnings by $(0.36 * 0.407=) 0.15$, or real annual earnings by $16 \%$. Separate estimations for each skill group give estimates of similar magnitude. ${ }^{36}$ Similarly, the effects of the log mean years of education of co-national men aged 18-60 living in the neighborhood on individual employment and earnings are positive, but insignificant. $^{37}$

Next, I investigate whether the size of the co-ethnic network in the neighborhood also affects individual labor market outcomes. I do so by estimating the effect of the log percentage co-national men aged 18-60 living in the neighborhood of residence 2-6 years after immigration using 2SLS by replacing the indicator for current residence in a socially deprived neighborhood $\mathrm{D}_{j l(t+s)}$ in Eq. (3) by this explanatory variable. As instruments I use the log percentage co-national men aged 18-60 in the assigned neighborhood in year $t$ and an indicator for no other co-national men living in the assigned neighborhood in year $t$.

Table 10, Panel B, columns 3 and 6, presents the 2SLS estimates of the log percentage co-national men aged 18-60 living in the neighborhood and Panel $C$ the first-stage regression estimates. The first instrumental variable is a strong predictor; the $t$-statistic is 3.5 in the employment model and 3.2 in the earnings model, corresponding to F-statistics of 12 and 10 , respectively. According to the 2SLS estimates, an increase in the percentage co-national men significantly raises individual real annual earnings (using a $10 \%$ significance level), while the impact on individual employment is insignificant but positive. The first-mentioned result is very interesting. It is consistent with the findings of Edin et al.

\footnotetext{
36 Results are available upon request.

37 Since I was unable to find a strong instrument for the log mean real annual earnings of co-national men aged 18-60 living in the neighborhood in the earnings model, Table 10 does not report the 2SLS estimates of the effects of that variable.
} 
Effects of the quality and size of the co-national network in the neighborhood. Balanced panel of male refugees, 2-6 years since immigration. Source: Administrative registers from Statistics Denmark.

\begin{tabular}{|c|c|c|c|c|c|c|c|c|}
\hline & \multicolumn{4}{|c|}{ Dep. var.: Employed in November } & \multicolumn{4}{|c|}{ Dep. var.: Ln(real annual earnings) } \\
\hline & (1) & (2) & (3) & (4) & (5) & (6) & (7) & (8) \\
\hline \multicolumn{9}{|l|}{ Panel A: OLS estimates of chacteristics of current neighborhood of residence } \\
\hline $\operatorname{Ln}($ employment rate of co-national men aged $18-60)$ & $\begin{array}{l}0.008^{* *} \\
(0.001)\end{array}$ & - & - & $\begin{array}{l}0.010^{* *} \\
(0.001)\end{array}$ & $\begin{array}{l}0.055^{* *} \\
(0.003)\end{array}$ & - & - & $\begin{array}{l}0.059^{* *} \\
(0.003)\end{array}$ \\
\hline $\operatorname{Ln}($ mean years of education of co-national men aged $18-60)$ & - & $\begin{array}{l}0.001 \\
(0.001)\end{array}$ & - & - & - & $\begin{array}{l}0.001 \\
(0.008)\end{array}$ & - & - \\
\hline Ln(pct. co-national men aged $18-60)$ & - & - & $\begin{array}{l}-0.007^{* *} \\
(0.002)\end{array}$ & $\begin{array}{l}-0.019^{* *} \\
(0.002)\end{array}$ & - & - & $\begin{array}{l}-0.015 \\
(0.010)\end{array}$ & $\begin{array}{l}-0.059^{* *} \\
(0.009)\end{array}$ \\
\hline \multicolumn{9}{|l|}{ Panel B: 2SLS estimates of characteristics of current neighborhood of residence } \\
\hline $\operatorname{Ln}($ employment rate of co-national men aged $18-60)$ & $\begin{array}{l}0.009 \\
(0.011)\end{array}$ & - & - & $\begin{array}{l}0.007 \\
(0.015)\end{array}$ & $\begin{array}{l}0.407^{* *} \\
(0.154)\end{array}$ & - & - & $\begin{array}{l}0.528^{*} \\
(0.259)\end{array}$ \\
\hline $\operatorname{Ln}($ mean years of education of co-national men aged $18-60)$ & - & $\begin{array}{l}0.032 \\
(0.043)\end{array}$ & - & - & - & $\begin{array}{l}0.522 \\
(0.406)\end{array}$ & - & - \\
\hline $\operatorname{Ln}($ pct. co-national men aged $18-60)$ & - & - & $\begin{array}{l}0.012 \\
(0.021)\end{array}$ & $\begin{array}{l}0.003 \\
(0.027)\end{array}$ & - & - & $\begin{array}{l}0.449^{+} \\
(0.234)\end{array}$ & $\begin{array}{l}-0.452 \\
(0.518)\end{array}$ \\
\hline \multicolumn{9}{|l|}{ Panel C: First stage of 2SLS } \\
\hline \multicolumn{9}{|l|}{ Effects on In(employment rate of co-national men living in current neighborhood of residence) } \\
\hline Ln(employment rate of co-national men aged 18-60 living in assigned neighborhood) & $\begin{array}{l}0.028^{* *} \\
(0.007)\end{array}$ & - & - & $\begin{array}{l}0.024^{* *} \\
(0.007)\end{array}$ & $\begin{array}{l}0.014 \\
(0.011)\end{array}$ & - & - & $\begin{array}{l}0.011 \\
(0.012)\end{array}$ \\
\hline No co-national men aged $18-60$ in assigned neighborhood & $\begin{array}{l}-0.451^{* *} \\
(0.068)\end{array}$ & - & - & $\begin{array}{l}-0.315^{* *} \\
(0.068)\end{array}$ & $\begin{array}{l}-0.310^{* *} \\
(0.083)\end{array}$ & - & - & $\begin{array}{l}-0.198^{*} \\
(0.090)\end{array}$ \\
\hline F-test of joint insignificance of the exclusion restrictions: & $\begin{array}{l}\mathrm{F}(2,76897) \\
85^{5 *}\end{array}$ & - & - & $\begin{array}{l}\mathrm{F}(3,76896) \\
70^{* *}\end{array}$ & $\begin{array}{l}\mathrm{F}(2,24454) \\
13^{2 *}\end{array}$ & - & - & $\begin{array}{l}F(3,24453) \\
12^{*}\end{array}$ \\
\hline \multicolumn{9}{|l|}{$\begin{array}{l}\text { Effect on } \ln \text { (mean years of education of co-national men aged 18-60 living in current neighborhood } \\
\text { of residence) }\end{array}$} \\
\hline Ln(mean years of education of co-national men aged 18-60 in assigned neighborhood) & - & $\begin{array}{l}0.017^{* *} \\
(0.006)\end{array}$ & - & - & - & $\begin{array}{l}0.014^{+} \\
(0.008)\end{array}$ & - & - \\
\hline No co-national men aged $18-60$ in assigned neighborhood & - & $\begin{array}{l}-0.014 \\
(0.050)\end{array}$ & - & - & - & $\begin{array}{l}-0.020 \\
(0.058)\end{array}$ & - & - \\
\hline F-test of joint significance of the exclusion restrictions & - & $\begin{array}{l}\mathrm{F}(2,76897) \\
37^{* *}\end{array}$ & - & - & - & $\begin{array}{l}\mathrm{F}(2,24454) \\
9^{* *}\end{array}$ & - & - \\
\hline $\begin{array}{l}\text { Effects on In(pct. co-national men living in current neighborhood of residence) } \\
\text { Ln(pct. co-national men aged 18-60 living in assigned neighborhood) }\end{array}$ & - & - & $\begin{array}{l}0.110^{* *} \\
(0.030)\end{array}$ & $\begin{array}{l}0.111^{* *} \\
(0.029)\end{array}$ & - & - & $\begin{array}{l}0.067^{* *} \\
(0.019)\end{array}$ & $\begin{array}{l}0.068 \\
(0.018)\end{array}$ \\
\hline F-test of joint insignificance of the exclusion restrictions & - & - & $\begin{array}{l}\mathrm{F}(2,76897) \\
304\end{array}$ & $\begin{array}{l}\mathrm{F}(3,76896) \\
203^{* *}\end{array}$ & - & - & $\begin{array}{l}\mathrm{F}(2,24454) \\
35^{*}\end{array}$ & $\begin{array}{l}\mathrm{F}(3,24453) \\
24\end{array}$ \\
\hline Number of observations & 77,180 & & & & 24,725 & & & \\
\hline Number of individuals & 15,436 & & & & 8864 & & & \\
\hline
\end{tabular}

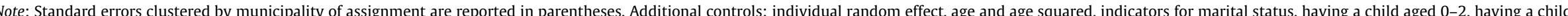

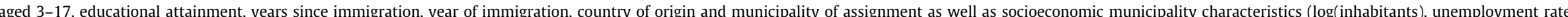
$\log ($ average gross income), $\log ($ pct. non-Western immigrants) and $\log ($ pct. co-nationals)). Values of control variables are measured in the year of assignment.

*** $P<0.01$.

$P<0.05$

$+P<0.1$. 
(2003) and Damm (2009) of a positive effect of the number of conationals living in the municipality on individual real annual earnings.

However, the size and the quality of the local ethnic enclave are positively correlated because larger ethnic enclaves in Denmark are more established. Therefore, the positive and significant effect of log percentage co-nationals aged 18-60 living in the neighborhood of residence on the individual's real annual earnings 26 years after immigration may be upward biased due to omission of ethnic enclave quality. As previously mentioned, the empirical model in Eq. (1) used by Edin et al. (2003) and Damm (2009) to identify the effects of the size of the ethnic enclave did not control for the quality of the ethnic enclave due to lack of municipal variation in the quality of the ethnic enclave. However, at the neighborhood level the quality of the ethnic enclave varies enough to disentangle the effects of the size and the quality of the local ethnic enclave. To this end, I add the log employment rate of co-national men aged 18-60 living in the neighborhood of residence 2-6 years after immigration as an additional explanatory variable to the model with the log of percent co-national men aged 18-60 living in the neighborhood of residence 2-6 years after immigration as the explanatory variable. As instruments I use the log employment rate of co-national men aged $18-60$, the log percentage co-national men aged 18-60 and an indicator for no other co-national men aged 18-60 living in the neighborhood of assignment in year $t$. The instruments are strong.

Table 10, Panel B, columns 4 and 8, presents the results. In response to inclusion of the log employment rate of co-national men aged 18-60 living in the neighborhood, the 2SLS estimate of the log percentage co-national men aged 18-60 living in the neighborhood approaches zero in the employment model and turns negative but insignificant in the earnings model. By contrast, the 2SLS estimate of the log employment rate of co-national men aged 1860 living in the neighborhood on real annual earnings 2-6 years after immigration remains positive and significant. These findings provide quasi-experimental evidence that it is the quality - not the size - of the co-ethnic network in the neighborhood that matters for immigrants' real annual earnings.

The findings presented in Sections 4.1 and 4.2 raise the following questions: First, does the quality of non-Western immigrant neighbors or the quality of the co-ethnic neighbors matter more for individual labor market outcomes? Second, which measure of the quality of immigrant and co-ethnic contacts matters more for the individual labor market outcomes: the mean skill-level or their employment rate? The answers to these questions can shed light on the mechanisms by which ethnic neighborhood-based contacts affect individual labor market outcomes. I answer these questions in the next subsection.

\subsection{Two-stage least squares estimation of the separate effects of immigrant versus co-ethnic residence-based networks}

In Table 11, I first test whether the quality of non-Western immigrant neighbors or the quality of the co-ethnic neighbors matters more for the individual's labor market outcomes (columns 1 and 4). I do so by including both the log employment rate of nonWestern immigrant men aged 18-60 and the log employment rate of co-national men aged 18-60 who live in the municipality of residence as explanatory variables in Eq. (3) (instead of $\left.D_{j l(t+s)}\right){ }^{38}$

\footnotetext{
38 As instruments I use the log employment rate of non-Western immigrant men aged 18-60 and the log employment rate of co-national men aged 18-60 who live in the municipality of assignment in the year of assignment as well as two indicators for no other non-Western immigrant men aged 18-60 and no other co-national men aged 18-60 living in the municipality of assignment in the year of assignment. The instruments are strong.
}

In the employment model the 2SLS estimates of both variables (reported in Panel B, column 1) decrease in response to inclusion of the other variable; this is seen from comparison with the 2SLS estimates reported in column 1 of Tables 9 and 10. The estimates suggest that the individual's employment probability is positively affected by a high employment rate of male non-Western immigrant neighbors but even more so by a high employment rate of co-national male neighbors.

Turning to the earnings model, the 2SLS estimates (reported in Panel B, column 5) show that the finding of a positive and significant earnings effect of the log employment rate of co-national men aged 18-60 living the neighborhood reported in Table 10, column 5 , is robust to inclusion of the log employment rate of non-Western immigrant men aged 18-60 living in the neighborhood as an additional explanatory variable; the magnitude of the 2SLS estimate is virtually unchanged. By contrast, the estimate of the earnings effect of log employment rate of non-Western immigrant men aged 18-60 living in the neighborhood reported in Table 9, column 6, approaches zero and turns insignificant in response to inclusion of the log employment rate of co-national men aged 18-60 living in the neighborhood. This provides evidence that immigrant real annual earnings are positively affected by the employment rate of co-national men aged 18-60 living in the neighborhood of residence and not affected by the employment rate of non-Western immigrant men from other source countries living in the neighborhood of residence.

From Table 9, column 5, we learn that exposure to well-educated non-Western immigrant male neighbors is more important for the individual's employment probability than exposure to non-Western immigrant male neighbors with a relatively high employment rate. Therefore, as the next step in Table 11, I report estimates from the IV-model in Eq. (3) with three endogenous explanatory variables entered jointly: the log employment rate of co-national men, the log employment rate of non-Western immigrant men and the log mean years of education of non-Western immigrant men - living in the neighborhood of residence 26 years after immigration. As instruments I use the log employment rate of co-national men in the assigned neighborhood, the log employment rate of non-Western immigrant men in the assigned neighborhood and the log mean years of education of non-Western immigrant men in the assigned neighborhood, all measured in year $t$, and an indicator for no other co-national men living in the assigned neighborhood in the year of assignment. With $F$-statistics between 30 and 45 in the employment model, the instruments appear to be strong. According to the 2SLS estimates in Panel B, column 2, only the log mean years of education of non-Western immigrant men has a significant effect on the individual's employment probability and the effect is positive as expected. By contrast, the instruments for two of the endogenous explanatory variables in the earnings model are weak and hence the 2SLS estimates in Table 11, column 5 , should be interpreted with caution. Taking the 2 SLS estimates at face value, the log employment rate of co-national men in the neighborhood of residence appears to have the greatest impact on individual's real annual earnings.

Note also that estimation of an IV-model with three endogenous explanatory variables gives rise to concern: For one thing, it is difficult to understand where the identification comes from, i.e. which instrumental variable exactly identifies which effect. Moreover, even in the specifications in which the $F$-stats for joint insignificance of the exclusion restrictions exceeds 10 , the set of instrumental variables may only weakly predict the outcome if the predicted values of the endogenous variables are highly correlated. Therefore, in the last specification reported in Table 11, columns 3 and 6, I report the estimates of a more parsimonious model which includes only the two most important neighborhood charac- 
Table 11

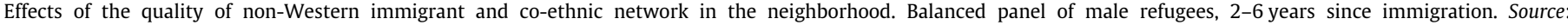
Administrative registers from Statistics Denmark.

\begin{tabular}{|c|c|c|c|c|c|c|}
\hline & \multicolumn{6}{|c|}{ Dependent variable } \\
\hline & \multicolumn{2}{|c|}{ Employed in November } & (3) & \multicolumn{3}{|c|}{ Ln(real annual earnings) } \\
\hline $\begin{array}{l}\text { Panel A: OLS estimates of chacteristics of current neighborhood of residence } \\
\text { Ln(employment rate of co-national men aged 18-60) }\end{array}$ & $\begin{array}{l}0.008^{* *} \\
(0.001)\end{array}$ & $\begin{array}{l}0.008^{* * *} \\
(0.001)\end{array}$ & $\begin{array}{l}0.009^{* * *} \\
(0.001)\end{array}$ & $\begin{array}{l}0.055^{* *} \\
(0.003)\end{array}$ & $\begin{array}{l}0.055^{* * *} \\
(0.003)\end{array}$ & $\begin{array}{l}0.055^{* *} \\
(0.003)\end{array}$ \\
\hline Ln(employment rate of non-Western immigrant men aged 18-60) & $\begin{array}{l}0.005^{* *} \\
(0.002)\end{array}$ & $\begin{array}{l}0.004^{*} \\
(0.002)\end{array}$ & - & $\begin{array}{l}0.007 \\
(0.011)\end{array}$ & $\begin{array}{l}0.006 \\
(0.011)\end{array}$ & - \\
\hline $\operatorname{Ln}($ mean years of education of non-Western immigrant men aged 18-60) & - & $\begin{array}{l}0.009^{* * *} \\
(0.001)\end{array}$ & $\begin{array}{l}0.010^{* *} \\
(0.001)\end{array}$ & - & $\begin{array}{l}0.031^{*} \\
(0.015)\end{array}$ & $\begin{array}{l}0.031^{*} \\
(0.015)\end{array}$ \\
\hline \multicolumn{7}{|l|}{ Panel B: 2SLS estimates of characteristics of current neighborhood of residence } \\
\hline $\mathrm{Ln}$ (employment rate of co-national men aged $18-60)$ & $\begin{array}{l}0.007 \\
(0.013)\end{array}$ & $\begin{array}{l}-0.003 \\
(0.013)\end{array}$ & $\begin{array}{l}-0.001 \\
(0.013)\end{array}$ & $\begin{array}{l}0.419^{*} \\
(0.202)\end{array}$ & $\begin{array}{l}0.329 \\
(0.225)\end{array}$ & $\begin{array}{l}0.344 \\
(0.232)\end{array}$ \\
\hline Ln(employment rate of non-Western immigrant men aged 18-60) & $\begin{array}{l}0.022 \\
(0.044)\end{array}$ & $\begin{array}{l}0.043 \\
(0.042)\end{array}$ & - & $\begin{array}{l}-0.006 \\
(0.510)\end{array}$ & $\begin{array}{l}0.240 \\
(0.461)\end{array}$ & - \\
\hline $\operatorname{Ln}($ mean years of education of non-Western immigrant men aged 18-60) & - & $\begin{array}{l}0.113^{*} \\
(0.057)\end{array}$ & $\begin{array}{l}0.149^{* *} \\
(0.057)\end{array}$ & - & $\begin{array}{l}0.940 \\
(0.976)\end{array}$ & $\begin{array}{l}1.358 \\
(1.525)\end{array}$ \\
\hline \multicolumn{7}{|l|}{ Panel C: First stage of 2SLS } \\
\hline $\begin{array}{l}\text { Ln(employment rate of co-national men aged 18-60 living in assigned } \\
\text { neighborhood) }\end{array}$ & $\begin{array}{l}0.027^{* *} \\
(0.007)\end{array}$ & $\begin{array}{l}0.027^{* *} \\
(0.007)\end{array}$ & $\begin{array}{l}0.028^{* *} \\
(0.007)\end{array}$ & $\begin{array}{l}0.013 \\
(0.011)\end{array}$ & $\begin{array}{l}0.013 \\
(0.011)\end{array}$ & $\begin{array}{l}0.013 \\
(0.011)\end{array}$ \\
\hline No co-national men aged $18-60$ in assigned neighborhood & $\begin{array}{l}-0.456 \\
(0.067)\end{array}$ & $\begin{array}{l}-0.456^{* *} \\
(0.071)\end{array}$ & $\begin{array}{l}-0.450^{* *} \\
(0.072)\end{array}$ & $\begin{array}{l}-0.316^{* * *} \\
(0.082)\end{array}$ & $\begin{array}{l}-0.289^{* *} \\
(0.082)\end{array}$ & $\begin{array}{l}-0.282^{* *} \\
(0.082)\end{array}$ \\
\hline F-test of joint insignificance of the exclusion restrictions: & $\begin{array}{l}\mathrm{F}(3,76896) \\
60^{* *}\end{array}$ & $\begin{array}{l}\mathrm{F}(4,76895) \\
45^{* *}\end{array}$ & $\begin{array}{l}\mathrm{F}(3,76896) \\
57^{* *}\end{array}$ & $\begin{array}{l}\mathrm{F}(3,24453) \\
10^{* *}\end{array}$ & $\begin{array}{l}F(4,24452) \\
8^{* *}\end{array}$ & $\begin{array}{l}\mathrm{F}(3,24453) \\
10^{* *}\end{array}$ \\
\hline \multicolumn{7}{|c|}{ Effect on In(employment rate of non-Western immigrant men aged 18-60 living in current neighborhood of residence): } \\
\hline $\begin{array}{l}\text { Ln(employment rate of non-Western immigrant men aged 18-60 living in assigned } \\
\text { neighborhood) }\end{array}$ & $\begin{array}{l}0.029^{* *} \\
(0.005)\end{array}$ & $\begin{array}{l}0.028^{* * *} \\
(0.005)\end{array}$ & - & $\begin{array}{l}0.026^{* *} \\
(0.005)\end{array}$ & $\begin{array}{l}0.024^{* * *} \\
(0.006)\end{array}$ & - \\
\hline F-test of joint insignificance of the exclusion restrictions & $\begin{array}{l}\mathrm{F}(3,76896) \\
60^{* *}\end{array}$ & $\begin{array}{l}\mathrm{F}(4,76895) \\
62^{* *}\end{array}$ & - & $\begin{array}{l}\mathrm{F}(3,24453) \\
18^{* *}\end{array}$ & $\begin{array}{l}\mathrm{F}(4,24452) \\
22^{* *}\end{array}$ & - \\
\hline \multicolumn{7}{|l|}{$\begin{array}{l}\text { Effect on } \ln \text { (mean years of education of non-Western immigrant men aged 18-60 } \\
\text { living in current neighborhood of residence) }\end{array}$} \\
\hline $\begin{array}{l}\text { Ln(mean years of education of non-Western immigrant men aged 18-60 in } \\
\text { assigned neighborhood) }\end{array}$ & - & $\begin{array}{l}0.025^{* * *} \\
(0.006)\end{array}$ & $\begin{array}{l}0.025^{* *} \\
(0.006)\end{array}$ & - & $\begin{array}{l}0.010 \\
(0.008)\end{array}$ & $\begin{array}{l}0.009 \\
(0.008)\end{array}$ \\
\hline F-test of joint insignificance of the exclusion restrictions & - & $\begin{array}{l}\mathrm{F}(4,76895) \\
30^{* *}\end{array}$ & $\begin{array}{l}\mathrm{F}(3,76896) \\
39^{* *}\end{array}$ & - & $\begin{array}{l}F(4,24452) \\
5^{* *}\end{array}$ & $\begin{array}{l}F(3,24453) \\
5^{* *}\end{array}$ \\
\hline Number of observations & & 77,180 & & & 24,725 & \\
\hline Number of individuals & & 15,436 & & & 8864 & \\
\hline
\end{tabular}

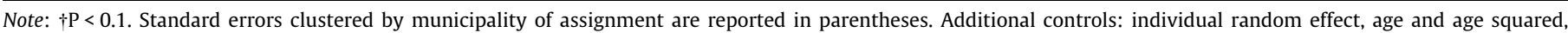

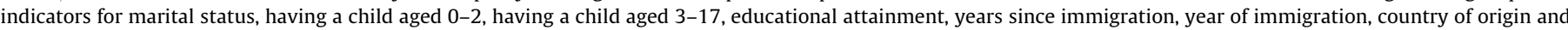

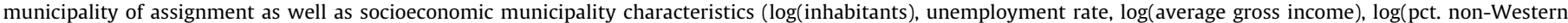
immigrants) and $\log ($ pct. co-nationals $)$ ). Values of control variables are measured in the year of assignment.

*** $P<0.01$.

${ }^{*} P<0.05$.

teristics for individual employment and earnings as endogenous explanatory variables: the log employment rate of co-national men and the log mean years of education of non-Western immigrant men - living in the neighborhood 2-6 years after immigration. In the parsimonious model, the estimated employment effect of log mean years of education of non-Western immigrant men aged 18-60 living in the neighborhood 2-6 years after immigration is of the same magnitude as in the specification in which it was entered as the only endogenous explanatory variable (Table 9 , column 2). Similarly, the estimated earnings effect in the parsimonious model of the log employment rate of co-national men aged 18-60 living in the neighborhood of residence 2-6 years after immigration is of similar magnitude as in the specification in which it was entered separately (Table 10, column 5 ).

\subsection{Robustness checks of two-stage least squares estimates of the neighborhood quality}

As robustness checks, I first exclude refugees who were assigned to Copenhagen City and re-do the analysis. The 2SLS esti- mates for this subsample are reported in Appendix Table A7. My findings of (i) a positive employment effect of a log increase in the mean years of education of non-Western immigrant men aged 18-60 living in the neighborhood (reported in Table 9) and (ii) a positive earnings effect of a log increase in the employment rate of co-national men aged 18-60 living in the neighborhood of residence (reported in Table 10) are robust to such an exclusion. Secondly, I investigate whether findings (i) and (ii) are driven by refugees from a particular source country. That is not the case; they are general findings across source countries (results are available upon request).

\subsection{Do the network effects vary with time in the neighborhood?}

In Tables 7-11 I have estimated the average effects of neighborhood characteristics on individual labor market outcomes 26 years after immigration $(s=2, \ldots, 6)$, i.e. without allowing the effects to vary with the number of years spent in the host country. However, it is reasonable to think that time spent in the neighborhood is what matters for outcomes, because it takes time to get ac- 
Table 12

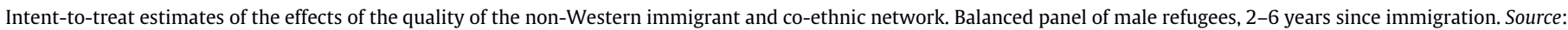
Administrative registers from Statistics Denmark.

\begin{tabular}{|c|c|c|c|c|c|}
\hline & \multicolumn{5}{|c|}{ Years since migration } \\
\hline & 2 & 3 & 4 & 5 & 6 \\
\hline $\begin{array}{l}\text { Panel A: Dependent variable: Employment in November } \\
\text { Ln(mean years of education of non-Western immigrant men aged 18-60 in assigned neighborhood) }\end{array}$ & $\begin{array}{l}0.003 \\
(0.003)\end{array}$ & $\begin{array}{l}0.000 \\
(0.003)\end{array}$ & $\begin{array}{l}0.000 \\
(0.003)\end{array}$ & $\begin{array}{l}0.009^{* *} \\
(0.003)\end{array}$ & $\begin{array}{l}0.009^{*} \\
(0.004)\end{array}$ \\
\hline $\begin{array}{l}\text { Number of observations } \\
\text { Number of individuals }\end{array}$ & & & $\begin{array}{l}77,180 \\
15,436\end{array}$ & & \\
\hline $\begin{array}{l}\text { Panel B: Dependent variable: Ln(real annual earnings) } \\
\text { Ln(employment rate of co-national men aged } 18-60 \text { in assigned neighborhood) }\end{array}$ & $\begin{array}{l}0.014^{\dagger} \\
(0.007)\end{array}$ & $\begin{array}{l}0.009 \\
(0.006)\end{array}$ & $\begin{array}{l}0.010^{\dagger} \\
(0.005)\end{array}$ & $\begin{array}{l}0.013^{*} \\
(0.005)\end{array}$ & $\begin{array}{l}0.007 \\
(0.005)\end{array}$ \\
\hline $\begin{array}{l}\text { Number of observations } \\
\text { Number of individuals }\end{array}$ & & & $\begin{array}{l}24,725 \\
8864\end{array}$ & & \\
\hline
\end{tabular}

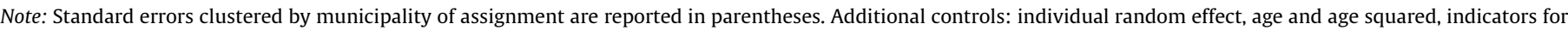

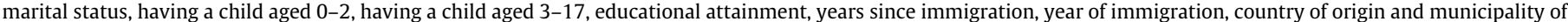

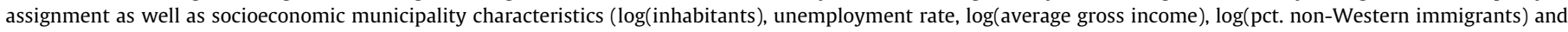
$\log ($ pct. co-nationals $)$ ). Values of control variables are measured in the year of assignment.

** $P<0.01$

${ }^{*} P<0.05$.

$\dagger P<0.1$.

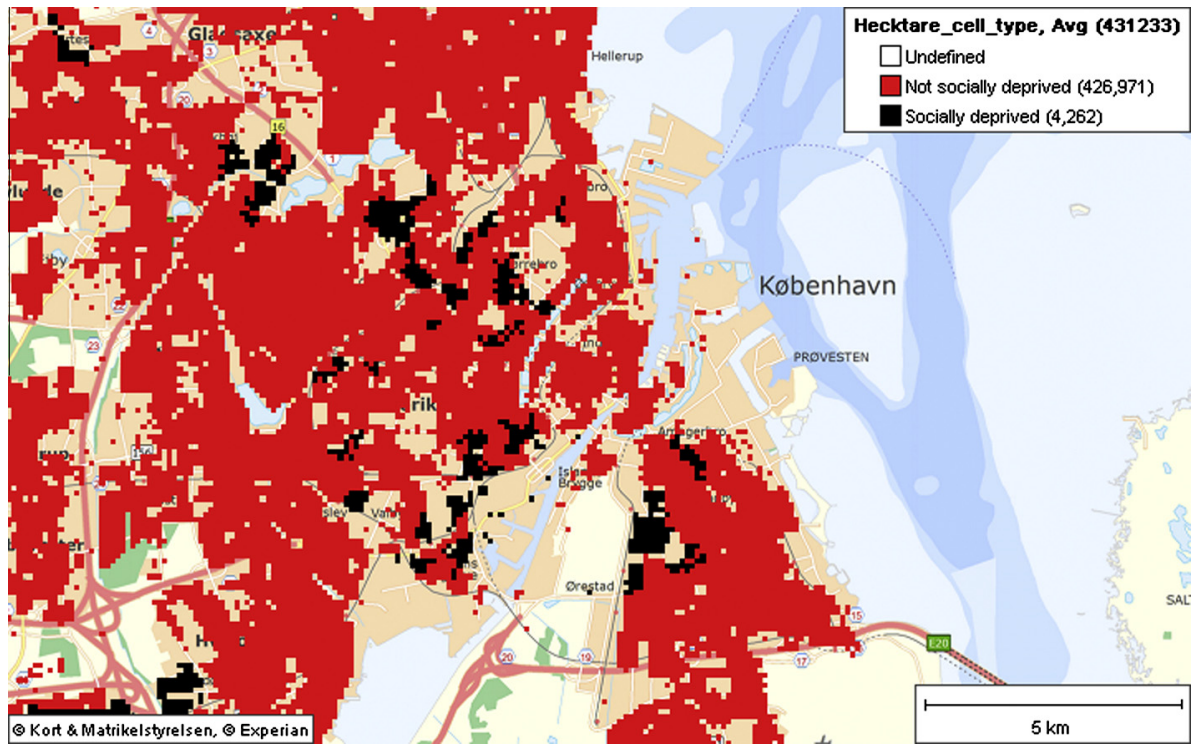

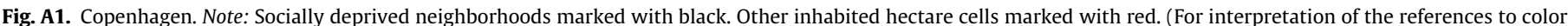
in this figure legend, the reader is referred to the web version of this article.)

quainted with neighbors and therefore for information to propagate through the network. If so, the neighborhood effects are cumulative in nature. ${ }^{39}$ To investigate whether the neighborhood effects are cumulative, for each $s$ I estimate (i) the intent to treat (ITT) estimates corresponding to the 2SLS estimates in Table 9, column 2, and (ii) the ITT estimates corresponding to the 2SLS estimates in Table 10, column 5 . I do so by estimating the ITT estimates after interaction of the explanatory variable of interest with years since immigration dummies $\boldsymbol{\delta}_{s}(s=2, \ldots, 6)$ using the balanced panel of male refugees, 2-6 years since migration, and the same controls as in Eq. (3). If the effects increase with time spent in Denmark, it suggests that the effects are cumulative. I report the ITT estimates of the interaction terms in Table 12. As reported in Panel A, the interaction term in the employment model is significant only 5 and 6 years after

\footnotetext{
${ }^{39}$ For support of this hypothesis see e.g. the empirical findings of Edin et al. (2003) in the context of returns to living in an ethnic enclave and of Glaeser and Maré (2001) in the context of urban wage premiums.
}

immigration. This suggests that the effects of the quality of nonWestern immigrant neighbors are cumulative in nature. By contrast, as shown in Panel B the effects of the quality of co-national neighbors are positive in all years since immigration and significant 2,4 and 5 years since immigration and do not increase with time spent in Denmark. A potential explanation for these contrasting time patterns could be that assigned refugees acquire co-ethnic contacts fast whereas it takes years to acquire contacts from other source countries due to language and cultural barriers. As a consequence, information about job opportunities propagates fast through the coethnic network in the neighborhood and more slowly through the overall immigrant network in the neighborhood.

\section{Conclusion}

The main purpose of this paper has been to investigate whether the quality of the neighborhood affects the individual's labor mar- 


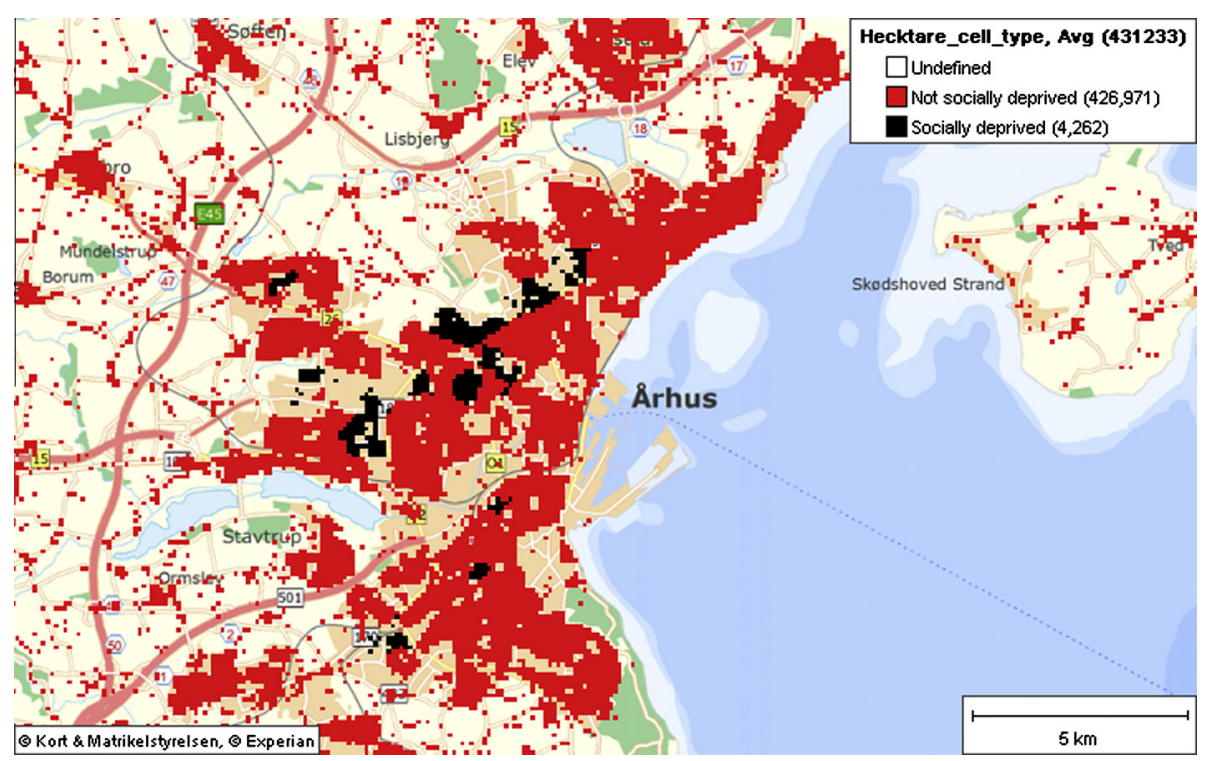

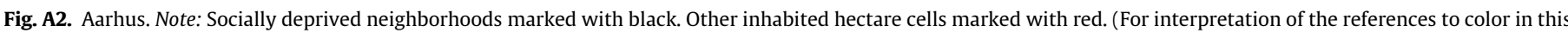
figure legend, the reader is referred to the web version of this article.)

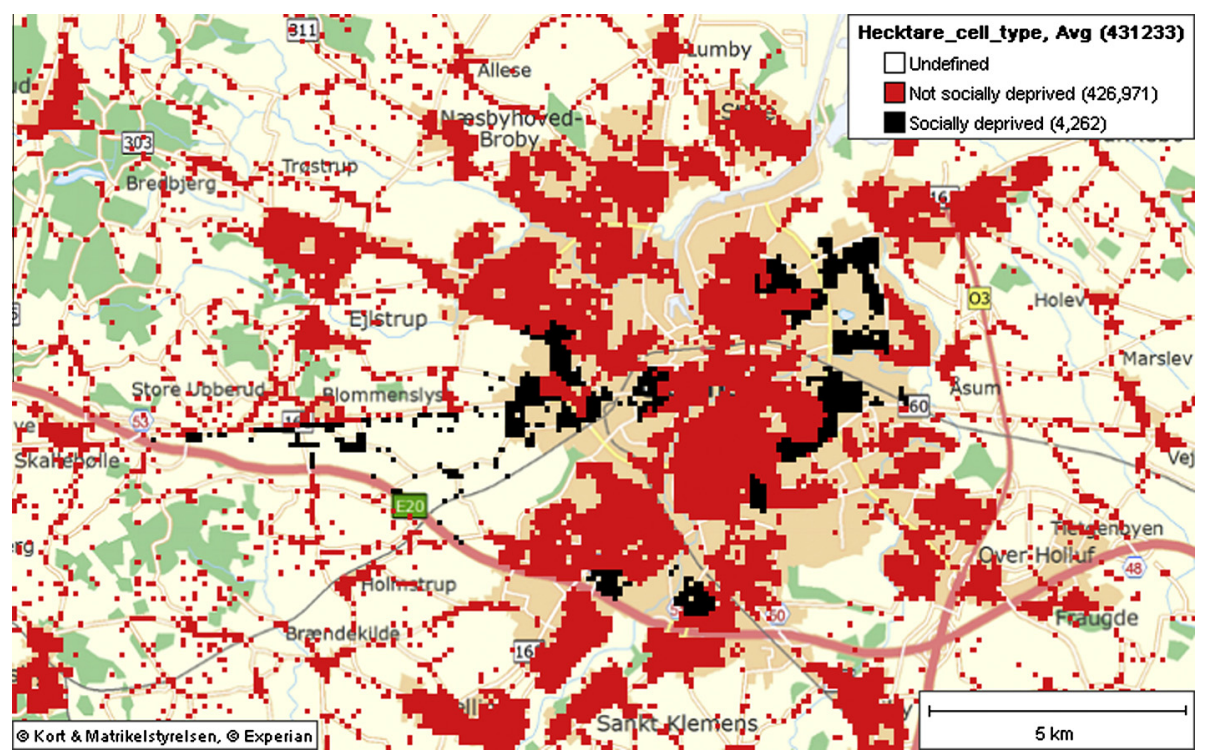

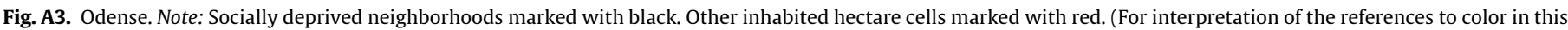
figure legend, the reader is referred to the web version of this article.)

ket outcomes. I have shown that both Ordinary Least Squares and Propensity Score Matching estimation give biased estimates of the effect of neighborhood quality. The reason is that individuals sort across neighborhoods in terms of unobserved personal characteristics, violating the assumption of selection on observables. To deal with location sorting, I have exploited a spatial dispersal policy on refugees in Denmark which resulted in quasi-random neighborhood assignment of refugees.

My quasi-experimental findings suggest four main conclusions. First, individuals sort across neighborhoods. Second, taking account of sorting, residence in a socially deprived neighborhood (defined as a neighborhood in which the employment rate is not above 60\%) does not affect individual labor market outcomes. This finding is in line with previous experimental (Katz et al., 2001; Kling et al., 2007; Sanbonmatsu et al., 2011; Ludwig et al., 2012) and quasi-experimental findings (Oreopoulos, 2003). Thirdly, a relatively high average skill level of non-Western immigrants living in the neighborhood increases the individual's employment probability, while a relatively high employment rate among co-nationals living in the neighborhood raises individual real annual earnings. By contrast, the effect of the percentage of co-nationals living in the neighborhood is insignificant. Fourthly, the effects of the qual- 


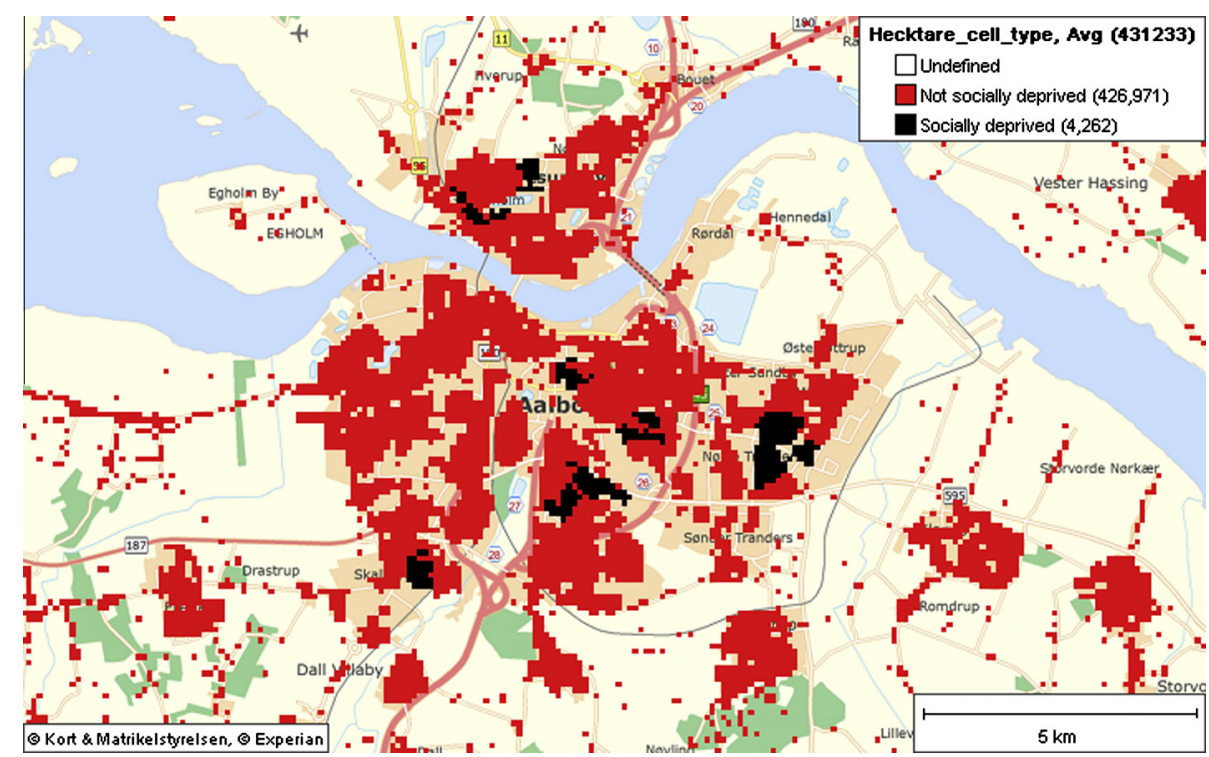

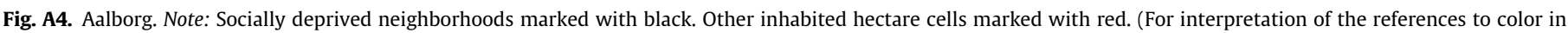
this figure legend, the reader is referred to the web version of this article.)

Table A1

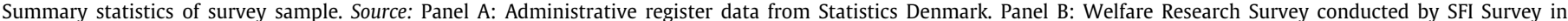
Denmark in 2006.

\begin{tabular}{|c|c|c|c|c|}
\hline & \multicolumn{2}{|l|}{ All } & \multicolumn{2}{|c|}{ Unemployed } \\
\hline & $\begin{array}{l}\text { Danes } \\
\text { (1) }\end{array}$ & $\begin{array}{l}\text { Immigrants } \\
\text { (2) }\end{array}$ & $\begin{array}{l}\text { Danes } \\
\text { (3) }\end{array}$ & $\begin{array}{l}\text { Immigrants } \\
\text { (4) }\end{array}$ \\
\hline \multicolumn{5}{|l|}{ Panel A } \\
\hline Woman & $\begin{array}{l}0.529 \\
(0.500)\end{array}$ & $\begin{array}{l}0.448 \\
(0.498)\end{array}$ & $\begin{array}{l}0.739 \\
(0.442)\end{array}$ & $\begin{array}{l}0.62 \\
(0.490)\end{array}$ \\
\hline Age & $\begin{array}{l}32.6 \\
(7.7)\end{array}$ & $\begin{array}{l}34.0 \\
(7.5)\end{array}$ & $\begin{array}{l}32.2 \\
(7.3)\end{array}$ & $\begin{array}{l}34.6 \\
(6.9)\end{array}$ \\
\hline Married & $\begin{array}{l}0.42 \\
(0.494)\end{array}$ & $\begin{array}{l}0.685 \\
(0.465)\end{array}$ & $\begin{array}{l}0.435 \\
(0.499)\end{array}$ & $\begin{array}{l}0.738 \\
(0.441)\end{array}$ \\
\hline Child aged $0-2$ & $\begin{array}{l}0.181 \\
(0.385)\end{array}$ & $\begin{array}{l}0.199 \\
(0.399)\end{array}$ & $\begin{array}{l}0.319 \\
(0.469)\end{array}$ & $\begin{array}{l}0.278 \\
(0.449)\end{array}$ \\
\hline Child aged 3-17 & $\begin{array}{l}0.487 \\
(0.5)\end{array}$ & $\begin{array}{l}0.611 \\
(0.488)\end{array}$ & $\begin{array}{l}0.493 \\
(0.504)\end{array}$ & $\begin{array}{l}0.711 \\
(0.454)\end{array}$ \\
\hline Immigration year & - & $\begin{array}{l}1989.4 \\
(8.1)\end{array}$ & - & $\begin{array}{l}1990.9 \\
(8.2)\end{array}$ \\
\hline \multicolumn{5}{|l|}{ Educational attainment } \\
\hline $0-9$ years of education & $\begin{array}{l}0.009 \\
(0.095)\end{array}$ & $\begin{array}{l}0.231 \\
(0.422)\end{array}$ & 0 & $\begin{array}{l}0.399 \\
(0.491)\end{array}$ \\
\hline $10-12$ years of education & $\begin{array}{l}0.651 \\
(0.477)\end{array}$ & $\begin{array}{l}0.493 \\
(0.500)\end{array}$ & $\begin{array}{l}0.841 \\
(0.369)\end{array}$ & $\begin{array}{l}0.407 \\
(0.492)\end{array}$ \\
\hline More than 12 years of education & $\begin{array}{l}0.34 \\
(0.474)\end{array}$ & $\begin{array}{l}0.275 \\
(0.447)\end{array}$ & $\begin{array}{l}0.159 \\
(0.369)\end{array}$ & $\begin{array}{l}0.194 \\
(0.396)\end{array}$ \\
\hline Unknown educational attainment & 0 & $\begin{array}{l}0.001 \\
(0.036)\end{array}$ & 0 & 0 \\
\hline \multicolumn{5}{|l|}{ Country of origin } \\
\hline Denmark & 1 & 0 & 1 & 0 \\
\hline Iran & 0 & $\begin{array}{l}0.389 \\
(0.488)\end{array}$ & 0 & $\begin{array}{l}0.316 \\
(0.466)\end{array}$ \\
\hline Turkey & 0 & $\begin{array}{l}0.35 \\
(0.477)\end{array}$ & 0 & $\begin{array}{l}0.426 \\
(0.495)\end{array}$ \\
\hline Pakistan & 0 & $\begin{array}{l}0.262 \\
(0.440)\end{array}$ & 0 & $\begin{array}{l}0.259 \\
(0.439)\end{array}$ \\
\hline \multicolumn{5}{|l|}{ Labor market outcomes } \\
\hline Employed in November 2006/2007 & $\begin{array}{l}0.923 \\
(0.266)\end{array}$ & $\begin{array}{l}0.764 \\
(0.425)\end{array}$ & $\begin{array}{l}0.652 \\
(0.480)\end{array}$ & $\begin{array}{l}491 \\
(0.501)\end{array}$ \\
\hline Work experience since 1980 (full-time years) & $\begin{array}{l}6.83 \\
(8.45)\end{array}$ & $\begin{array}{l}3.13 \\
(4.25)\end{array}$ & $\begin{array}{l}4.38 \\
(6.21)\end{array}$ & $\begin{array}{l}2.14 \\
(3.30)\end{array}$ \\
\hline \multicolumn{5}{|l|}{ Municipality of residence characteristics } \\
\hline $\log ($ inhabitants $)$ & $\begin{array}{l}10.65 \\
(1.38)\end{array}$ & $\begin{array}{l}11.41 \\
(1.24)\end{array}$ & $\begin{array}{l}10.40 \\
(1.42)\end{array}$ & $\begin{array}{l}11.52 \\
(1.30)\end{array}$ \\
\hline
\end{tabular}


Table A1 (continued)

\begin{tabular}{|c|c|c|c|c|}
\hline & \multicolumn{2}{|l|}{ All } & \multicolumn{2}{|c|}{ Unemployed } \\
\hline & $\begin{array}{l}\text { Danes } \\
\text { (1) }\end{array}$ & $\begin{array}{l}\text { Immigrants } \\
(2)\end{array}$ & $\begin{array}{l}\text { Danes } \\
(3)\end{array}$ & $\begin{array}{l}\text { Immigrants } \\
\text { (4) }\end{array}$ \\
\hline Log(mean gross income) & $\begin{array}{l}12.31 \\
(0.10)\end{array}$ & $\begin{array}{l}12.30 \\
(0.10)\end{array}$ & $\begin{array}{l}12.29 \\
(0.08)\end{array}$ & $\begin{array}{l}12.28 \\
(0.08)\end{array}$ \\
\hline Unemployment rate & $\begin{array}{l}4.60 \\
(1.45)\end{array}$ & $\begin{array}{l}4.90 \\
(1.16)\end{array}$ & $\begin{array}{l}4.99 \\
(1.81)\end{array}$ & $\begin{array}{l}5.10 \\
(1.11)\end{array}$ \\
\hline Number of observations & 874 & 1575 & 69 & 263 \\
\hline \multicolumn{5}{|l|}{ Panel B } \\
\hline Employed in the week before the interview & $\begin{array}{l}0.763 \\
(0.425)\end{array}$ & $\begin{array}{l}0.596 \\
(0.491)\end{array}$ & 0 & 0 \\
\hline Proficient in Danish & - & $\begin{array}{l}0.634 \\
(0.482)\end{array}$ & - & $\begin{array}{l}0.456 \\
(0.500)\end{array}$ \\
\hline Proficient in English & $\begin{array}{l}0.882 \\
(0.323)\end{array}$ & $\begin{array}{l}0.56 \\
(0.497)\end{array}$ & $\begin{array}{l}0.826 \\
(0.382)\end{array}$ & $\begin{array}{l}0.35 \\
(0.478)\end{array}$ \\
\hline \multicolumn{5}{|l|}{ Reason for immigration } \\
\hline Family-reunification with spouse & - & $\begin{array}{l}0.345 \\
(0.476)\end{array}$ & - & $\begin{array}{l}0.217 \\
(0.413)\end{array}$ \\
\hline Family-reunification with parents & - & $\begin{array}{l}0.283 \\
(0.451)\end{array}$ & - & $\begin{array}{l}0.483 \\
(0.501)\end{array}$ \\
\hline Refugee & - & $\begin{array}{l}0.291 \\
(0.454)\end{array}$ & - & $\begin{array}{l}0.232 \\
(0.423)\end{array}$ \\
\hline Work or education in Denmark (DK) & - & $\begin{array}{l}0.04 \\
(0.196)\end{array}$ & - & $\begin{array}{l}0.03 \\
(0.172)\end{array}$ \\
\hline Other & - & $\begin{array}{l}0.034 \\
(0.182)\end{array}$ & - & $\begin{array}{l}0.03 \\
(0.172)\end{array}$ \\
\hline \multicolumn{5}{|l|}{ Network size } \\
\hline Number of acquaintances in DK & $\begin{array}{l}34.82 \\
(26.35)\end{array}$ & $\begin{array}{l}29.28 \\
(25.68)\end{array}$ & $\begin{array}{l}26.45 \\
(23.04)\end{array}$ & $\begin{array}{l}25.43 \\
(24.99)\end{array}$ \\
\hline Number of acquaintances in DK above average & $\begin{array}{l}0.443 \\
(0.497)\end{array}$ & $\begin{array}{l}0.387 \\
(0.487)\end{array}$ & $\begin{array}{l}0.319 \\
(0.469)\end{array}$ & $\begin{array}{l}0.33 \\
(0.47)\end{array}$ \\
\hline Majority of immigrant acquaintances in DK & - & $\begin{array}{l}0.268 \\
(0.443)\end{array}$ & - & $\begin{array}{l}0.384 \\
(0.487)\end{array}$ \\
\hline \multicolumn{5}{|l|}{ High employment rate of } \\
\hline Family members in DK & $\begin{array}{l}0.954 \\
(0.209)\end{array}$ & $\begin{array}{l}0.58 \\
(0.494)\end{array}$ & $\begin{array}{l}0.928 \\
(0.261)\end{array}$ & $\begin{array}{l}0.517 \\
(0.501)\end{array}$ \\
\hline Close friends in DK & $\begin{array}{l}0.935 \\
(0.247)\end{array}$ & $\begin{array}{l}0.795 \\
(0.404)\end{array}$ & $\begin{array}{l}0.884 \\
(0.323)\end{array}$ & $\begin{array}{l}0.726 \\
(0.447)\end{array}$ \\
\hline Acquaintances in DK & $\begin{array}{l}0.891 \\
(0.311)\end{array}$ & $\begin{array}{l}0.78 \\
(0.414)\end{array}$ & $\begin{array}{l}0.812 \\
(0.394)\end{array}$ & $\begin{array}{l}0.722 \\
(0.449)\end{array}$ \\
\hline \multicolumn{5}{|l|}{ High level of education of } \\
\hline Family members in DK & $\begin{array}{l}0.891 \\
(0.311)\end{array}$ & $\begin{array}{l}0.391 \\
(0.488)\end{array}$ & $\begin{array}{l}0.841 \\
(0.369)\end{array}$ & $\begin{array}{l}0.274 \\
(0.447)\end{array}$ \\
\hline Close friends in DK & $\begin{array}{l}0.852 \\
(0.355)\end{array}$ & $\begin{array}{l}0.563 \\
(0.496)\end{array}$ & $\begin{array}{l}0.797 \\
(0.405)\end{array}$ & $\begin{array}{l}0.453 \\
(0.498)\end{array}$ \\
\hline Acquaintances in DK & $\begin{array}{l}0.736 \\
(0.441)\end{array}$ & $\begin{array}{l}0.48 \\
(0.500)\end{array}$ & $\begin{array}{l}0.696 \\
(0.464)\end{array}$ & $\begin{array}{l}0.361 \\
(0.481)\end{array}$ \\
\hline Number of observations & 874 & 1575 & 69 & 263 \\
\hline
\end{tabular}

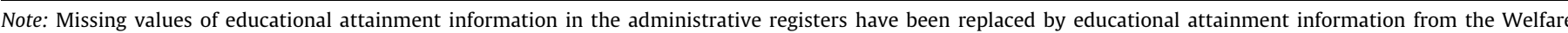
Research Survey conducted by SFI Survey in 2006 in Denmark.

ity of non-Western immigrant neighbors are cumulative, whereas the effects of the quality of co-national neighbors are of similar magnitude across years since migration.

I interpret these findings as evidence of the following. First, quality - rather than the size - of residence-based networks is important for labor market outcomes, consistent with the theories proposed by Montgomery (1994) and Calvó-Armengol and Jackson (2004). Second, residence-based job information networks are ethnically stratified, in line with evidence from observational studies by Topa (2001) and Hellerstein et al. (2011). Living in a socially deprived neighborhood does not hamper labor market outcomes of non-Western immigrants since - in contrast to my priors - the average educational level of non-Western immigrant men across socially deprived neighborhoods ( 7.8 years over the 1986-1998) is close to the average across all neighborhoods (8.1 years over the 1986-1998 period). Instead the low employment rates of residents in socially deprived neighborhoods are primarily the result of the large overrepresentation of non-Western immigrants and descendants in socially deprived neighborhoods combined with the generally low employment rate of non-Western immigrants and descendants compared to that of natives. An additional explanation - of second-order importance - is that immigrants who settle in socially deprived neighborhoods are negatively selected from the overall group of immigrants, both in terms of observable and unobservable personal characteristics.

Dustmann et al. (2011) find that employment through referral is associated with a short-term wage premium. The economic intuition is that referrals reduce the uncertainty about the workers 
Table A2

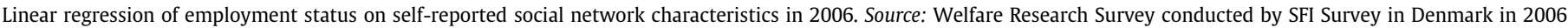
linked with administrative registers from Statistics Denmark.

\begin{tabular}{|c|c|c|c|c|c|c|c|c|c|c|}
\hline & \multicolumn{10}{|c|}{ Dependent variable } \\
\hline & \multicolumn{5}{|c|}{$\begin{array}{l}\text { Employed in the week before the interview (2006) } \\
\text { All }\end{array}$} & \multicolumn{5}{|c|}{$\begin{array}{l}\text { Employed in November } 2006 \text { or November } 2007 \\
\text { Unemployed }\end{array}$} \\
\hline & \multicolumn{3}{|l|}{ Danes } & \multicolumn{2}{|c|}{ Immigrants } & \multicolumn{3}{|l|}{ Danes } & \multicolumn{2}{|c|}{ Immigrants } \\
\hline & $(1)$ & $(2)$ & (3) & (4) & (5) & (6) & (7) & $(8)$ & (9) & $(10)$ \\
\hline \multicolumn{11}{|l|}{ Social network characteristics } \\
\hline Number of acquaintances & $\begin{array}{l}0.032^{* * *} \\
(0.012)\end{array}$ & $\begin{array}{l}-0.026 \\
(0.051)\end{array}$ & $\begin{array}{l}0.016 \\
(0.013)\end{array}$ & $\begin{array}{l}0.062^{*} \\
(0.025)\end{array}$ & $\begin{array}{l}0.026 \\
(0.016)\end{array}$ & $\begin{array}{l}0.026 \\
(0.108)\end{array}$ & $\begin{array}{l}-0.005 \\
(0.134)\end{array}$ & $\begin{array}{l}0.005 \\
(0.041)\end{array}$ & $\begin{array}{l}-0.079 \\
(0.079)\end{array}$ & $\begin{array}{l}0.045 \\
(0.053)\end{array}$ \\
\hline No. acquaintances $*$ high employment rate of acq. & - & $\begin{array}{l}0.063 \\
(0.052)\end{array}$ & - & $\begin{array}{l}-0.055^{*} \\
(0.024)\end{array}$ & - & - & $\begin{array}{l}0.035 \\
(0.173)\end{array}$ & - & $\begin{array}{l}0.105 \\
(0.083)\end{array}$ & - \\
\hline No. acquaintances $*$ majority of immigrant acq. & - & - & - & - & $\begin{array}{l}-0.041^{\dagger} \\
(0.024)\end{array}$ & - & - & - & - & $\begin{array}{l}-0.085 \\
(0.051)\end{array}$ \\
\hline Majority of immigrant acquaintances & - & - & - & - & $\begin{array}{l}-0.013 \\
(0.023)\end{array}$ & - & - & - & - & $\begin{array}{l}-0.115^{\dagger} \\
(0.068)\end{array}$ \\
\hline \multicolumn{11}{|l|}{ High employment rate of } \\
\hline Family in DK & $\begin{array}{l}-0.048 \\
(0.068)\end{array}$ & $\begin{array}{l}-0.047 \\
(0.068)\end{array}$ & $\begin{array}{l}0.024 \\
(0.033)\end{array}$ & $\begin{array}{l}0.024 \\
(0.033)\end{array}$ & $\begin{array}{l}0.026 \\
(0.034)\end{array}$ & $\begin{array}{l}-0.276 \\
(0.343)\end{array}$ & $\begin{array}{l}-0.269 \\
(0.350)\end{array}$ & $\begin{array}{l}-0.118 \\
(0.071)\end{array}$ & $\begin{array}{l}-0.116 \\
(0.071)\end{array}$ & $\begin{array}{l}-0.116 \\
(0.072)\end{array}$ \\
\hline Close friends in DK & $\begin{array}{l}0.276^{* *} \\
(0.080)\end{array}$ & $\begin{array}{l}0.287^{* *} \\
(0.079)\end{array}$ & $\begin{array}{l}0.111^{*} \\
(0.044)\end{array}$ & $\begin{array}{l}0.112^{*} \\
(0.044)\end{array}$ & $\begin{array}{l}0.113^{*} \\
(0.044)\end{array}$ & $\begin{array}{l}0.006 \\
(0.199)\end{array}$ & $\begin{array}{l}0.006 \\
(0.202)\end{array}$ & $\begin{array}{c}-0.041 \\
(0.065)\end{array}$ & $\begin{array}{c}-0.043 \\
(0.066)\end{array}$ & $\begin{array}{l}-0.042 \\
(0.067)\end{array}$ \\
\hline Acquaintances in DK & $\begin{array}{l}0.093^{*} \\
(0.047)\end{array}$ & $\begin{array}{l}0.097^{*} \\
(0.046)\end{array}$ & $\begin{array}{l}0.080 \\
(0.025)\end{array}$ & $\begin{array}{l}0.066^{* *} \\
(0.024)\end{array}$ & $\begin{array}{l}0.082^{* *} \\
(0.026)\end{array}$ & $\begin{array}{l}0.410^{*} \\
(0.185)\end{array}$ & $\begin{array}{l}0.409^{*} \\
(0.186)\end{array}$ & $\begin{array}{l}0.135^{\dagger} \\
(0.069)\end{array}$ & $\begin{array}{l}0.176^{*} \\
(0.072)\end{array}$ & $\begin{array}{l}0.130 \\
(0.065)\end{array}$ \\
\hline \multicolumn{11}{|l|}{ High skill level of } \\
\hline Family in DK & $\begin{array}{l}-0.023 \\
(0.049)\end{array}$ & $\begin{array}{l}-0.029 \\
(0.050)\end{array}$ & $\begin{array}{l}-0.003 \\
(0.025)\end{array}$ & $\begin{array}{l}-0.003 \\
(0.026)\end{array}$ & $\begin{array}{l}-0.005 \\
(0.025)\end{array}$ & $\begin{array}{l}0.277 \\
(0.167)\end{array}$ & $\begin{array}{l}0.276 \\
(0.170)\end{array}$ & $\begin{array}{l}0.039 \\
(0.077)\end{array}$ & $\begin{array}{l}0.033 \\
(0.080)\end{array}$ & $\begin{array}{l}0.032 \\
(0.079)\end{array}$ \\
\hline Close friends in DK & $\begin{array}{l}0.109 \\
(0.060)\end{array}$ & $\begin{array}{l}0.108^{\dagger} \\
(0.061)\end{array}$ & $\begin{array}{l}0.008 \\
(0.023)\end{array}$ & $\begin{array}{l}0.009 \\
(0.023)\end{array}$ & $\begin{array}{l}0.06 \\
(0.023)\end{array}$ & $\begin{array}{r}-0.266 \\
(0.194)\end{array}$ & $\begin{array}{l}-0.263 \\
(0.200)\end{array}$ & $\begin{array}{l}0.004 \\
(0.077)\end{array}$ & $\begin{array}{l}0.013 \\
(0.080)\end{array}$ & $\begin{array}{c}-0.007 \\
(0.077)\end{array}$ \\
\hline Acquaintances in DK & $\begin{array}{l}-0.035 \\
(0.033)\end{array}$ & $\begin{array}{l}-0.032 \\
(0.033)\end{array}$ & $\begin{array}{l}0.025 \\
(0.027)\end{array}$ & $\begin{array}{l}0.024 \\
(0.027)\end{array}$ & $\begin{array}{l}0.025 \\
(0.028)\end{array}$ & $\begin{array}{l}-0.031 \\
(0.150)\end{array}$ & $\begin{array}{l}-0.027 \\
(0.156)\end{array}$ & $\begin{array}{l}-0.024 \\
(0.076)\end{array}$ & $\begin{array}{l}-0.025 \\
(0.075)\end{array}$ & $\begin{array}{l}-0.019 \\
(0.077)\end{array}$ \\
\hline $\mathrm{R}^{2}$ & 0.216 & 0.218 & 0.250 & 0.253 & 0.252 & 0.300 & 0.300 & 0.324 & 0.327 & 0.336 \\
\hline Number of observations & 874 & & & 1575 & & 69 & & & 263 & \\
\hline
\end{tabular}

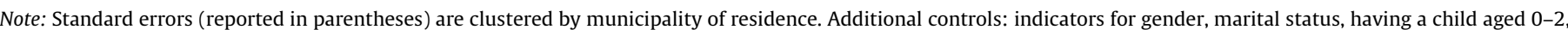

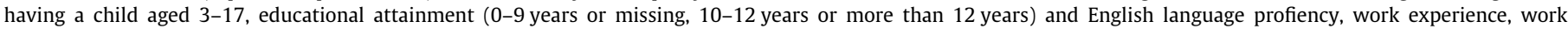

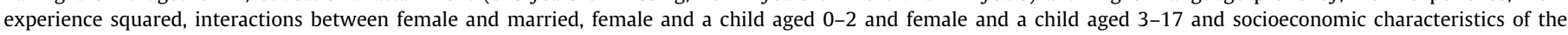

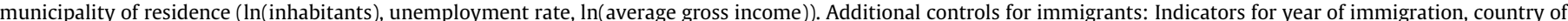

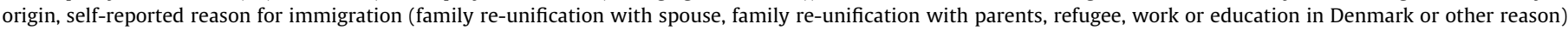

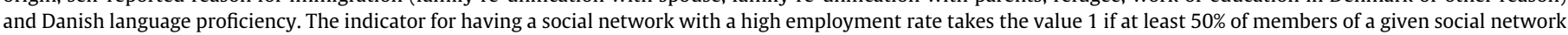

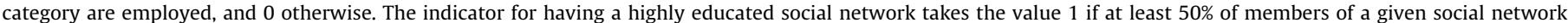

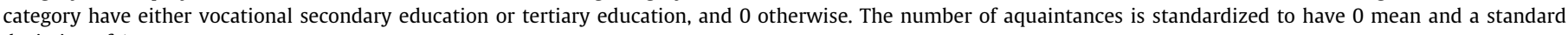
deviation of 1 .

** $P<0.01$.

${ }^{*} P<0.05$.

${ }^{\dagger} P<0.1$.

Table A3

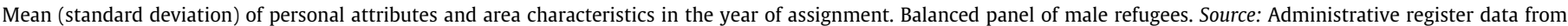
Statistics Denmark.

\begin{tabular}{|c|c|c|c|}
\hline & \multicolumn{3}{|c|}{ Individuals assigned to } \\
\hline & $\begin{array}{l}\text { All } \\
(1)\end{array}$ & $\begin{array}{l}\text { Socially deprived neighborhood } \\
(2)\end{array}$ & $\begin{array}{l}\text { Non-deprived neighborhood } \\
\text { (3) }\end{array}$ \\
\hline \multicolumn{4}{|l|}{ Personal attributes } \\
\hline Age & $\begin{array}{l}30.65 \\
(11.14)\end{array}$ & $\begin{array}{l}32.13 \\
(12.89)\end{array}$ & $\begin{array}{l}30.35 \\
(10.73)\end{array}$ \\
\hline Married & $\begin{array}{l}0.476 \\
(0.500)\end{array}$ & $\begin{array}{l}0.523 \\
(0.500)\end{array}$ & $\begin{array}{l}0.467 \\
(0.499)\end{array}$ \\
\hline Having a child aged $0-2$ & $\begin{array}{l}0.113 \\
(0.317)\end{array}$ & $\begin{array}{l}0.123 \\
(0.328)\end{array}$ & $\begin{array}{l}0.111 \\
(0.314)\end{array}$ \\
\hline Having a child aged 3-17 & $\begin{array}{l}0.188 \\
(0.390)\end{array}$ & $\begin{array}{l}0.231 \\
(0.422)\end{array}$ & $\begin{array}{l}0.179 \\
(0.383)\end{array}$ \\
\hline Year of immigration & $\begin{array}{l}1991 \\
(3.99)\end{array}$ & $\begin{array}{l}1992 \\
(3.72)\end{array}$ & $\begin{array}{l}1991 \\
(4.01)\end{array}$ \\
\hline \multicolumn{4}{|l|}{ Educational attainment } \\
\hline $0-9$ years of education & $\begin{array}{l}0.12 \\
(0.325)\end{array}$ & $\begin{array}{l}0.126 \\
(0.332)\end{array}$ & $\begin{array}{l}0.119 \\
(0.324)\end{array}$ \\
\hline $10-12$ years of education & $\begin{array}{l}0.39 \\
(0.488)\end{array}$ & $\begin{array}{l}0.375 \\
(0.484)\end{array}$ & $\begin{array}{l}0.392 \\
(0.488)\end{array}$ \\
\hline More than 12 years of education & $\begin{array}{l}0.166 \\
(0.372)\end{array}$ & $\begin{array}{l}0.169 \\
(0.375)\end{array}$ & $\begin{array}{l}0.165 \\
(0.372)\end{array}$ \\
\hline Unknown education & $\begin{array}{l}0.325 \\
(0.469)\end{array}$ & $\begin{array}{l}0.33 \\
(0.470)\end{array}$ & $\begin{array}{l}0.324 \\
(0.468)\end{array}$ \\
\hline
\end{tabular}


Table A3 (continued)

\begin{tabular}{|c|c|c|c|}
\hline & \multicolumn{3}{|c|}{ Individuals assigned to } \\
\hline & $\begin{array}{l}\text { All } \\
(1)\end{array}$ & $\begin{array}{l}\text { Socially deprived neighborhood } \\
\text { (2) }\end{array}$ & $\begin{array}{l}\text { Non-deprived neighborhood } \\
\text { (3) }\end{array}$ \\
\hline \multicolumn{4}{|l|}{ Country of origin } \\
\hline Iran & $\begin{array}{l}0.151 \\
(0.358)\end{array}$ & $\begin{array}{l}0.134 \\
(0.341)\end{array}$ & $\begin{array}{l}0.155 \\
(0.362)\end{array}$ \\
\hline Iraq & $\begin{array}{l}0.237 \\
(0.425)\end{array}$ & $\begin{array}{l}0.286 \\
(0.452)\end{array}$ & $\begin{array}{l}0.227 \\
(0.419)\end{array}$ \\
\hline Vietnam & $\begin{array}{l}0.073 \\
(0.300)\end{array}$ & $\begin{array}{l}0.114 \\
(0.318)\end{array}$ & $\begin{array}{l}0.065 \\
(0.246)\end{array}$ \\
\hline Sri Lanka & $\begin{array}{l}0.135 \\
(0.342)\end{array}$ & $\begin{array}{l}0.046 \\
(0.208)\end{array}$ & $\begin{array}{l}0.155 \\
(0.362)\end{array}$ \\
\hline No citizenship & $\begin{array}{l}0.203 \\
(0.403)\end{array}$ & $\begin{array}{l}0.168 \\
(0.374)\end{array}$ & $\begin{array}{l}0.211 \\
(0.408)\end{array}$ \\
\hline Ethiopia & $\begin{array}{l}0.008 \\
(0.086)\end{array}$ & $\begin{array}{l}0.007 \\
(0.083)\end{array}$ & $\begin{array}{l}0.008 \\
(0.087)\end{array}$ \\
\hline Afghanistan & $\begin{array}{l}0.038 \\
(0.192)\end{array}$ & $\begin{array}{l}0.045 \\
(0.207)\end{array}$ & $\begin{array}{l}0.037 \\
(0.189)\end{array}$ \\
\hline Somalia & $\begin{array}{l}0.154 \\
(0.361)\end{array}$ & $\begin{array}{l}0.201 \\
(0.401)\end{array}$ & $\begin{array}{l}0.145 \\
(0.352)\end{array}$ \\
\hline \multicolumn{4}{|l|}{ Municipality characteristics } \\
\hline Ln(inhabitants) & $\begin{array}{l}10.89 \\
(1.31)\end{array}$ & $\begin{array}{l}11.83 \\
(0.89)\end{array}$ & $\begin{array}{l}10.70 \\
(1.30)\end{array}$ \\
\hline Unemployment rate & $\begin{array}{l}9.85 \\
(2.97)\end{array}$ & $\begin{array}{l}11.22 \\
(2.45)\end{array}$ & $\begin{array}{l}9.58 \\
(2.99)\end{array}$ \\
\hline Ln(average gross income) & $\begin{array}{l}12.18 \\
(0.09)\end{array}$ & $\begin{array}{l}12.16 \\
(0.06)\end{array}$ & $\begin{array}{l}12.18 \\
(0.10)\end{array}$ \\
\hline Pct. non-Western immigrants & $\begin{array}{l}3.19 \\
(2.57)\end{array}$ & $\begin{array}{l}4.57 \\
(2.66)\end{array}$ & $\begin{array}{l}2.92 \\
(2.46)\end{array}$ \\
\hline Pct. co-nationals & $\begin{array}{l}0.18 \\
(0.20)\end{array}$ & $\begin{array}{l}0.28 \\
(0.22)\end{array}$ & $\begin{array}{l}0.16 \\
(0.20)\end{array}$ \\
\hline Number of observations & 15,436 & 2573 & 12,863 \\
\hline \multicolumn{4}{|l|}{ Neighborhood characteristics } \\
\hline Socially deprived neighborhood & $\begin{array}{l}0.167 \\
(0.361)\end{array}$ & 1 & 0 \\
\hline Employment rate of men aged $18-60$ & $\begin{array}{l}76.12 \\
(13.13)\end{array}$ & $\begin{array}{l}53.76 \\
(8.40)\end{array}$ & $\begin{array}{l}80.59 \\
(8.53)\end{array}$ \\
\hline Mean years of education of men aged $18-60$ & $\begin{array}{l}9.77 \\
(2.30)\end{array}$ & $\begin{array}{l}9.27 \\
(1.05)\end{array}$ & $\begin{array}{l}9.87 \\
(2.46)\end{array}$ \\
\hline Mean real annual earnings of men aged $18-60$ & $\begin{array}{l}164,741 \\
(57,557)\end{array}$ & $\begin{array}{l}107,597 \\
(26,146)\end{array}$ & $\begin{array}{l}176,171 \\
(55,271)\end{array}$ \\
\hline Employment rate of non-Western immigrant men aged 18-60 & $\begin{array}{l}37.40 \\
(23.67)\end{array}$ & $\begin{array}{l}27.98 \\
(10.89)\end{array}$ & $\begin{array}{l}39.28 \\
(25.05)\end{array}$ \\
\hline Mean years of education of non-Western immigrant men aged 18-60 & $\begin{array}{l}6.65 \\
(3.06)\end{array}$ & $\begin{array}{l}7.01 \\
(1.91)\end{array}$ & $\begin{array}{l}6.58 \\
(3.24)\end{array}$ \\
\hline Mean real annual earnings of non-Western immigrant men aged 18-60 & $\begin{array}{l}69,622 \\
(59,310)\end{array}$ & $\begin{array}{l}47,518 \\
(20,336)\end{array}$ & $\begin{array}{l}74,043 \\
(63,415)\end{array}$ \\
\hline Pct. non-Western immigrant men aged 18-60 & $\begin{array}{l}6.93 \\
(9.05)\end{array}$ & $\begin{array}{l}21.23 \\
(12.00)\end{array}$ & $\begin{array}{l}4.08 \\
(4.51)\end{array}$ \\
\hline Employment rate of co-national men aged $18-60$ & $\begin{array}{l}15.98 \\
(26.34)\end{array}$ & $\begin{array}{l}16.98 \\
(20.48)\end{array}$ & $\begin{array}{l}15.78 \\
(27.36)\end{array}$ \\
\hline Mean years of education of co-national men aged $18-60$ & $\begin{array}{l}3.89 \\
(4.62)\end{array}$ & $\begin{array}{l}6.38 \\
(3.84)\end{array}$ & $\begin{array}{l}3.39 \\
(4.60)\end{array}$ \\
\hline Mean real annual earnings of co-national men aged 18-60 & $\begin{array}{l}18,176 \\
(48,069)\end{array}$ & $\begin{array}{l}24,569 \\
(32,418)\end{array}$ & $\begin{array}{l}16,897 \\
(50,526)\end{array}$ \\
\hline Pct. co-national men aged $18-60$ & $\begin{array}{l}0.92 \\
(1.72)\end{array}$ & $\begin{array}{l}2.81 \\
(2.98)\end{array}$ & $\begin{array}{l}0.54 \\
(0.96)\end{array}$ \\
\hline \multicolumn{4}{|l|}{ Housing characteristics } \\
\hline Private rental & $\begin{array}{l}0.417 \\
(0.493)\end{array}$ & $\begin{array}{l}0.122 \\
(0.327)\end{array}$ & $\begin{array}{l}0.456 \\
(0.500)\end{array}$ \\
\hline Public rental & $\begin{array}{l}0.328 \\
(0.470)\end{array}$ & $\begin{array}{l}0.814 \\
(0.389)\end{array}$ & $\begin{array}{l}0.231 \\
(0.422)\end{array}$ \\
\hline Unknown rental type & $\begin{array}{l}0.255 \\
(0.436)\end{array}$ & $\begin{array}{l}0.064 \\
(0.244)\end{array}$ & $\begin{array}{l}0.293 \\
(0.455)\end{array}$ \\
\hline One-family house & $\begin{array}{l}0.179 \\
(0.384)\end{array}$ & $\begin{array}{l}0.003 \\
(0.056)\end{array}$ & $\begin{array}{l}0.215 \\
(0.411)\end{array}$ \\
\hline Row house & $\begin{array}{l}0.071 \\
(0.256)\end{array}$ & $\begin{array}{l}0.04 \\
(0.195)\end{array}$ & $\begin{array}{l}0.077 \\
(0.266)\end{array}$ \\
\hline Apartment & $\begin{array}{l}0.492 \\
(0.500)\end{array}$ & $\begin{array}{l}0.876 \\
(0.329)\end{array}$ & $\begin{array}{l}0.415 \\
(0.493)\end{array}$ \\
\hline Dormitory & $\begin{array}{l}0.032 \\
(0.175)\end{array}$ & $\begin{array}{l}0.052 \\
(0.222)\end{array}$ & $\begin{array}{l}0.027 \\
(0.163)\end{array}$ \\
\hline Other housing type & $\begin{array}{l}0.021 \\
(0.142)\end{array}$ & 0 & $\begin{array}{l}0.025 \\
(0.156)\end{array}$ \\
\hline Number of observations & 15,436 & 2573 & 12,863 \\
\hline
\end{tabular}


productivity. However, my finding that the quality of co-national neighbors affects earnings in contrast to the quality of immigrant neighbors suggests that only referral through co-national neighbors increases the individual's earnings, because only co-nationals know the true worker productivity, for instance from the worker's skill certificates from the source country.

Recall my final finding that the effect of the quality of co-national neighbors is time-constant whereas the effect of the quality of immigrant neighbors increases with time spent in the host country. It suggests that information about job opportunities propagates fast through the co-ethnic network in the neighborhood and more slowly through the overall immigrant network in the neighborhood.

My findings are economically significant. Having non-Western immigrant male neighbors whose mean skill level is one year above the average, increases the individual's employment probability by 1.6 percentage points. Similarly, a ten percentage points increase in the employment rate of co-national men aged 18-60 living in the neighborhood (around the mean) increases the individual's real annual earnings by $16 \%$.

The results have important policy implications for the labor market integration of immigrants. Existing evidence shows that policy makers in countries in which the authorities disperse newly recognized refugees across regions can increase the speed of employment and wage-assimilation of immigrants through refugee settlement in regions with low unemployment (Åslund and Rooth, 2007). This study adds that within high-employment regions, refugees should settle in neighborhoods with relatively high average skill levels among immigrants and relatively high employment rates among co-nationals. However, the intent-totreat estimates are very low compared to the two-stage least squares estimates (see e.g. Table 7). The reason is that few refugees stayed in the assigned neighborhood for a considerable number of years. Therefore, for such a settlement policy to work, the authorities may have to reduce the relocation rates of refugees, by also considering individual location wishes (given that they coincide with the overall goal of the settlement policy) and/or providing economic incentives to stay for some years. More generally, the findings of this study imply that successful local employment and skills-upgrading policies targeted at a subgroup of immigrants entail positive externalities for their immigrant acquaintances.

\section{Appendix A}

See Figs. A1-A4 and Tables A1-A7.

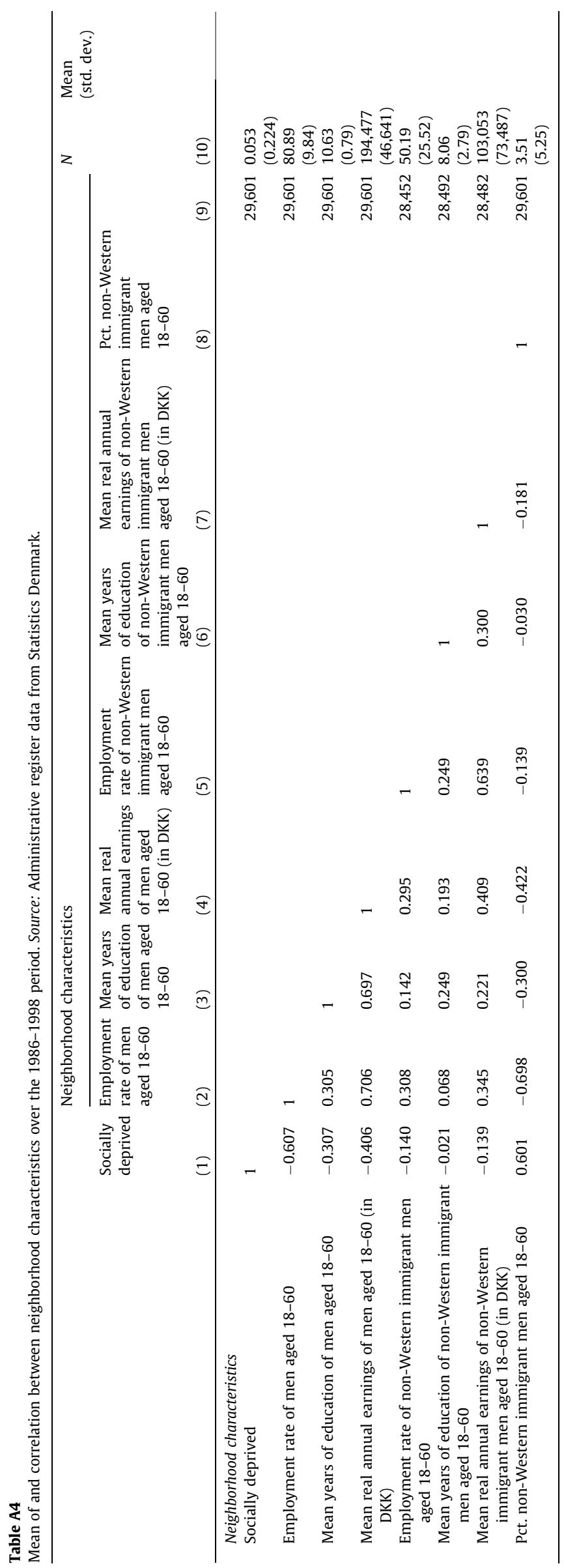




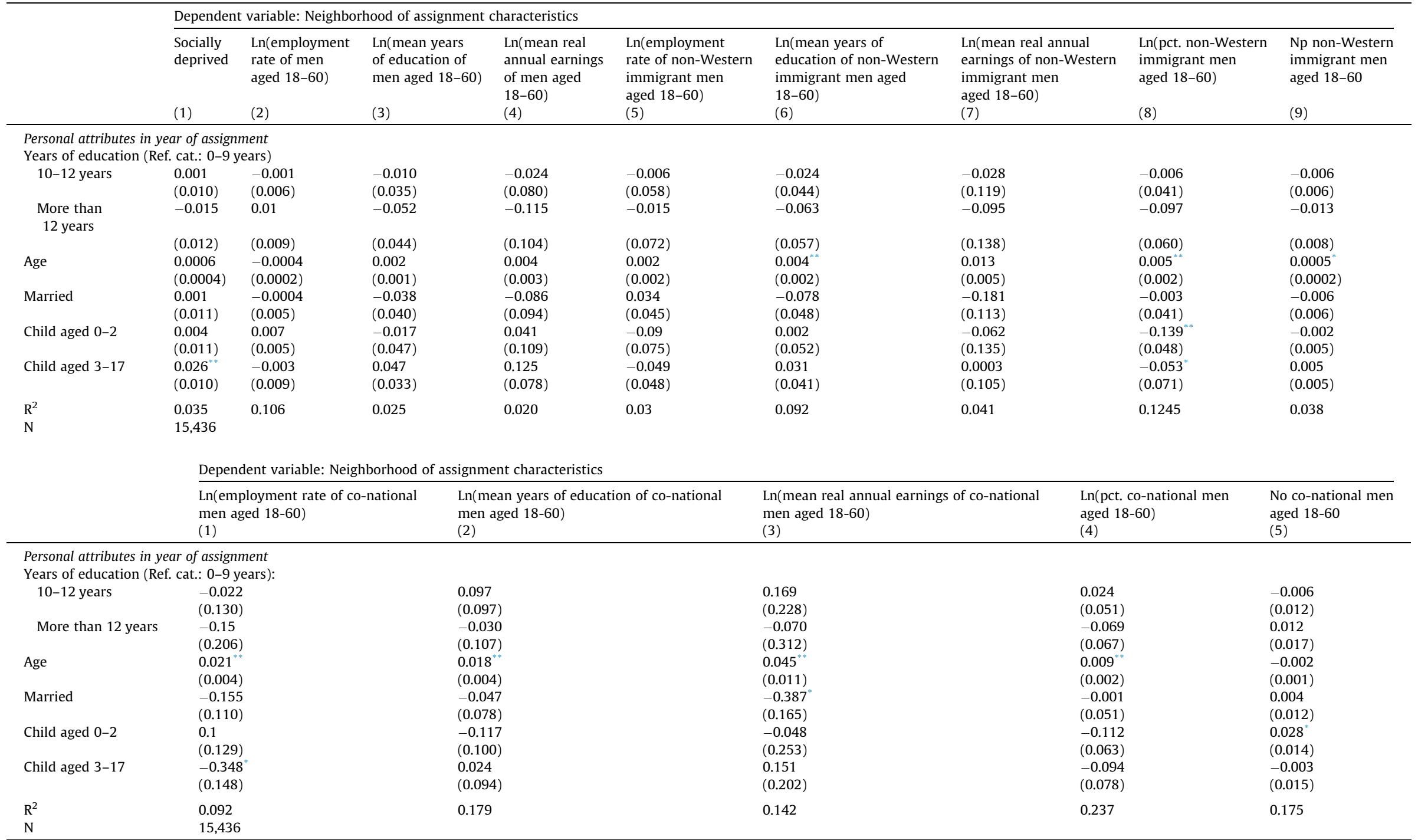

Note: Standard errors clustered by municipality of assignment are reported in parentheses. Additional controls: Dummies for country of origin, year of immigration and missing information about educational attainment.

${ }_{* *} \mathrm{P}<0.01$.

${ }^{*} \mathrm{P}<0.01$.
$\mathrm{P}<0.05$. 
Table A6

Share of individuals who have moved out of the location of assignment. Balanced panel of male refugee. Source: Administrative register data from Statistics Denmark.

\begin{tabular}{lll}
\hline & \multicolumn{2}{l}{ Moved out of } \\
\cline { 2 - 3 } & $\begin{array}{l}\text { Assigned neighborhood } \\
(1)\end{array}$ & $\begin{array}{l}\text { Assigned municipality } \\
(2)\end{array}$ \\
\hline Years since immigration & & \\
1 & 0 & 0 \\
2 & 0.645 & 0.334 \\
3 & 0.765 & 0.403 \\
4 & 0.813 & 0.448 \\
5 & 0.838 & 0.477 \\
6 & 0.856 & 0.501 \\
Number of observations & 15,436 & \\
\hline
\end{tabular}

Table A7

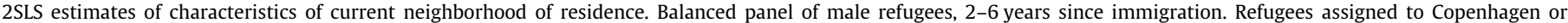
Frederiksberg municipality are excluded. Source: Administrative registers from Statistics Denmark.

\begin{tabular}{|c|c|c|c|c|c|c|c|c|c|c|c|c|}
\hline & (1) & $(2)$ & (3) & (4) & $(5)$ & (6) & $(7)$ & $(8)$ & (9) & $(10)$ & $(11)$ & $(12)$ \\
\hline \multicolumn{13}{|l|}{$\begin{array}{l}\text { Panel A: Dependent variable: Employed in November } \\
\text { Current neighborhood of residence }\end{array}$} \\
\hline Socially deprived & $\begin{array}{l}0.025 \\
(0.028)\end{array}$ & - & - & - & - & - & - & - & - & - & - & - \\
\hline Ln(employment rate of men aged 18-60) & - & $\begin{array}{l}-0.006 \\
(0.048)\end{array}$ & - & - & - & - & - & - & - & - & - & - \\
\hline $\operatorname{Ln}($ mean years of education of men aged $18-60$ ) & - & - & $\begin{array}{l}0.556 \\
(0.697)\end{array}$ & - & - & - & - & - & - & - & - & - \\
\hline Ln(employment rate of non-Western immigrant men aged 18-60) & - & - & - & $\begin{array}{l}0.076^{\dagger} \\
(0.041)\end{array}$ & - & $\begin{array}{l}0.083^{*} \\
(0.042)\end{array}$ & $\begin{array}{l}0.039 \\
(0.047)\end{array}$ & - & - & $\begin{array}{l}0.030 \\
(0.048)\end{array}$ & $\begin{array}{l}0.057 \\
(0.047)\end{array}$ & - \\
\hline $\begin{array}{l}\operatorname{Ln}(\text { mean years of education of non-Western immigrant men aged } \\
18-60)\end{array}$ & - & - & - & - & $\begin{array}{l}0.167^{* *} \\
(0.063)\end{array}$ & - & $\begin{array}{l}0.137^{*} \\
(0.068)\end{array}$ & - & - & - & $\begin{array}{l}0.134^{*} \\
(0.064)\end{array}$ & $\begin{array}{l}0.184^{* *} \\
(0.068)\end{array}$ \\
\hline Ln(pct. non-Western immigrant men aged 18-60) & - & - & - & - & - & $\begin{array}{l}-0.022^{\dagger} \\
(0.013)\end{array}$ & - & - & - & - & - & - \\
\hline Ln(employment rate of co-national men aged 18-60) & - & - & - & - & - & - & - & $\begin{array}{l}0.010 \\
(0.012)\end{array}$ & $\begin{array}{l}0.004 \\
(0.018)\end{array}$ & $\begin{array}{l}0.006 \\
(0.015)\end{array}$ & $\begin{array}{l}-0.010 \\
(0.016)\end{array}$ & $\begin{array}{l}-0.009 \\
(0.016)\end{array}$ \\
\hline Ln(pct. co-national men aged 18-60) & - & - & - & - & - & - & - & - & $\begin{array}{l}0.014 \\
(0.032)\end{array}$ & - & - & - \\
\hline Number of observations & 67,830 & & & & & & & & & & & \\
\hline Number of individuals & 13,566 & & & & & & & & & & & \\
\hline \multicolumn{13}{|l|}{$\begin{array}{l}\text { Panel B: Dependent variable: Ln(real annual earnings) } \\
\text { Current neighborhood of residence }\end{array}$} \\
\hline Socially deprived & $\begin{array}{l}0.375^{\dagger} \\
(0.215)\end{array}$ & - & - & - & - & - & - & - & - & - & - & - \\
\hline Ln(employment rate of men aged 18-60) & - & $\begin{array}{l}-0.519 \\
(0.415)\end{array}$ & - & - & - & - & - & - & - & - & - & - \\
\hline $\operatorname{Ln}($ mean years of education of men aged $18-60$ ) & - & - & $\begin{array}{l}0.842 \\
(1.360)\end{array}$ & - & - & - & - & - & - & - & - & - \\
\hline Ln(employment rate of non-Western immigrant men aged $18-60$ ) & - & - & - & $\begin{array}{l}0.788^{* *} \\
(0.301)\end{array}$ & & $\begin{array}{l}0.795 \\
(0.303)\end{array}$ & $\begin{array}{l}0.716 \\
(0.311)\end{array}$ & - & - & $\begin{array}{l}0.015 \\
(0.518)\end{array}$ & $\begin{array}{l}0.283 \\
(0.634)\end{array}$ & - \\
\hline $\begin{array}{l}\operatorname{Ln}(\text { mean years of education of non-Western immigrant men aged } \\
18-60)\end{array}$ & - & - & - & - & $\begin{array}{l}3.222 \\
(3.912)\end{array}$ & - & $\begin{array}{l}0.760 \\
(1.189)\end{array}$ & - & - & - & $\begin{array}{l}1.406 \\
(1.120)\end{array}$ & $\begin{array}{l}2.134 \\
(2.111)\end{array}$ \\
\hline Ln(pct. non-Western immigrant men aged 18-60) & - & - & - & - & - & $\begin{array}{l}-0.090 \\
(0.121)\end{array}$ & - & - & - & - & - & - \\
\hline Ln(employment rate of co-national men aged 18-60) & - & - & - & - & - & - & - & $\begin{array}{l}0.335^{*} \\
(0.137)\end{array}$ & $\begin{array}{l}0.418 \\
(0.257)\end{array}$ & $\begin{array}{l}0.346^{\dagger} \\
(0.205)\end{array}$ & $\begin{array}{l}0.253 \\
(0.297)\end{array}$ & $\begin{array}{l}0.252 \\
(0.303)\end{array}$ \\
\hline Ln(pct. co-national men aged 18-60) & - & - & - & - & - & - & - & - & $\begin{array}{l}-0.340 \\
(0.599)\end{array}$ & - & - & - \\
\hline Number of observations & 22,385 & & & & & & & & & & & \\
\hline Number of individuals & 7941 & & & & & & & & & & & \\
\hline
\end{tabular}

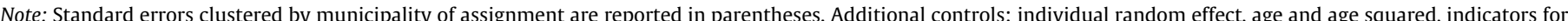

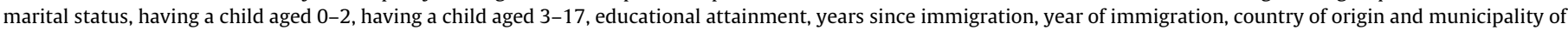

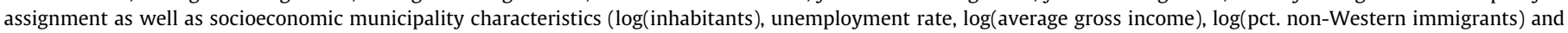
$\log$ (pct. co-nationals)). Values of control variables are measured in the year of assignment.

*** $P<0.01$

${ }^{*} P<0.05$

$+P<0.1$. 


\section{References}

Abadie, Alberto, Imbens, Guido W., 2006. Large sample properties of matching estimators for average treatment effects. Econometrica 74 (1), 235-267.

Addison, John T., Portugal, Pedro, 2002. Job search methods and outcomes. Oxford Economic Papers 54, 505-533.

Andersen, Hans Skifter, 2005. Den sociale og etniske udvikling i almene boligafdelinger (SBI 2005:10). Statens Byggeforskningsinstitut, København.

Andersson, Fredrik, Burgess, Simon, Lane, Julia, 2009. Do as the Neighbors Do: The Impact of Social Networks on Immigrant Employment. IZA DP No. 4423.

Åslund, Oluf, Rooth, Dan-Oluf, 2007. Do when and where matter? Initial labour market conditions and immigrant earnings. The Economic Journal 117 (March), 422-448.

Bayer, Patrick, Ross, Stephen L., Topa, Giorgio, 2008. Place of work and place of residence: informal hiring networks and labor market outcomes. Journal of Political Economy 116 (6), 1150-1196.

Bentolila, Samuel, Michelacci, Claudio, Suárez, Javier, 2010. Social contacts and occupational choice. Economica 77, 20-45.

Bertrand, Marianne, Luttmer, Erzo F.P., Mullainathan, Sendhil, 2000. Network effects and welfare cultures. Quarterly Journal of Economics 115 (3), 10191055.

Blau, David M., Robins, Philip K., 1990. Job search outcomes for the employed and unemployed. Journal of Political Economy 98 (3), 637-655.

Borjas, George, 1995. Ethnicity, neighborhoods and human-capital externalities. American Economic Review 85 (3), 365-390.

Calvó-Armengol, Antoni, Jackson, Matthew O., 2004. The effects of social networks on employment and inequality. American Economic Review 94 (3), 426-454.

Cingano, Frederico, Rosolia, Alfonso, 2012. People I know: job search and social networks. Journal of Labor Economics 30 (2), 291-332.

Coleman, David, Wadensjö, Eskil, 1999. Indvandringen til Danmark. Internationale og nationale perspektiver. Spektrum.

Damm, Anna P., 2009. Ethnic enclaves and immigrant labor market outcomes: quasi-experimental evidence. Journal of Labor Economics 27 (2), 281-314.

Damm, Anna P., Rosholm, Michael, 2010. Employment effects of spatial dispersal of refugees. Review of Economics of the Household 8 (1), 105-146.

Damm, Anna P., Schultz-Nielsen, Marie L., 2008. Danish neighborhoods: construction and relevance for measurement of residential segregation. Nationaløkonomisk Tidsskrift (Danish Economic Journal) 146, 241-262.

Damm, Anna P., Schultz-Nielsen, Marie L., Tranæs, Torben, 2006. En befolkning deler sig op? Gyldendal, Denmark.

Danish Refugee Council, 1986-1996. Annual Report

Danish Refugee Council, Central Integration Unit (CIU), 1996. Dansk Flygtningehjælps integrationsarbejde (Danish Refugee Council Integration Policy).

Deding, Mette, Fridberg, Torben, Jakobsen, Vibeke, 2008. Non-response in a survey among immigrants in Denmark. Survey Research Methods 2 (3), 107-121.

Dehejia, Rajeev H., Wahba, Sadek, 1999. Causal effects in nonexperimental studies: reevaluating the evaluation of training programs. Journal of the American Statistical Association 94(448), 1053-1062 (Applications and Case Studies).

Durlauf, Steven N., 2004. Neighborhood effects. In: Henderson, J. Vernon, Thisse, Jacques-Fran Cities and Geography (Chapter 50).

Dustmann, Christian, Glitz, Albrecht, Schönberg, Uta, 2011. Referral-based Job Search Networks. Norface Migration Discussion Paper No. 2011-12.

Edin, Per-Anders, Fredriksson, Peter, Åslund, Oluf, 2003. Ethnic enclaves and the economic success of immigrants - evidence from a natural experiment. Quarterly Journal of Economics 118, 329-357.

Glaeser, Edward L., Maré, David C., 2001. Cities and skills. Journal of Labor Economics 19 (2), 316-342.

Granovetter, Mark, 1973. The strength of weak ties. American Journal of Sociology 78 (6), 1360-1380.
Granovetter, Mark, 1974, 1995. Getting a Job: A Study of Contacts and Careers University of Chicago Press, Chicago.

Gregg, Paul, Wadsworth, Jonathan, 1996. How effective are state employment agencies? Jobcentre use and job matching in Britain. Oxford Bulletin of Economics and Statistics 58 (3), 443-467.

Hellerstein, Judith K., McInerney, Melissa, Neumark, David, 2011. Neighbors and coworkers: the importance of residential labor market networks. Journal of Labor Economics 29 (4), 659-695.

Holzer, Harry.J., 1988. Search methods use by unemployed youth. Journal of Labor Economics 6 (1), 1-20.

Husted, Leif, Nielsen, Helena Skyt, Rosholm, Michael, Smith, Nina, 2001 Employment and wage assimilation of first-generation male immigrants in Denmark. International Journal of Manpower 22 (1).

Ioannides, Yannis M., Loury, Linda Datcher, 2004. Job information networks, neighborhood effects, and inequality. Journal of Economic Literature 42 (4), 1056-1093.

Katz, Lawrence F., Kling, Jeffrey R., Liebman, Jeffrey B., 2001. Moving to opportunity in Boston: early results of a randomized mobility experiment. Quarterly Journa of Economics 116 (2), 607-654.

Kling, Jeffrey R., Liebman, Jeffrey B., Katz, Lawrence F., 2007. Experimental analysis of neighborhood effects. Econometrica 75, 83-119.

Ludwig, J., Duncan, G., Gennetian, L., Katz, L., Kessler, R., Kling, J., Sanbonmatsu, L. 2012. Neighborhood effects on the long-term well-being of low-income adults. Science 337 (21), 1505-1510.

Mogensen, Gunnar V., Matthiessen, Poul Chr., 2000. Integration i Danmark omkring årtusindskiftet. Aarhus Universitetsforlag.

Montgomery, James D., 1991. Social networks and labor-market outcomes: toward an economic analysis. American Economic Review 81 (5), 1408-1418.

Montgomery, James D., 1994. Weak ties, employment, and inequality: an equilibrium analysis. American Journal of Sociology 99 (5), 1212-1236.

Munshi, Kaivan, 2003. Networks in the modern economy: Mexican migrants in the US labor market. Quarterly Journal of Economics 118 (2), 549-599.

Oreopoulos, Philip, 2003. The long-run consequences of living in a poor neighborhood. Quarterly Journal of Economics 118 (4), 1533-1575.

Pellizari, Michele, 2010. Do friends and relatives really help in getting a good job? Industrial and Labor Relations Review 63 (3), 494-510.

Rees, Albert, 1966. Labor economics: effects of more knowledge. Information networks in labor market. American Economic Review (Papers and Proceedings) $56(1 / 2), 559-566$.

Rosenbaum, Paul R., Rubin, Donald B., 1983. The central role of the propensity score in observational studies for causal effects. Biometrika 70 (1), 41-55.

Ross, Steve., 2011. Social interactions within cities: neighborhood environments and peer relationships. In: Brooks, Nancy, Donaghy, Kieran, Knaap, Gerrit-Jan (Eds.), The Oxford Handbook of Urban Economics and Planning (Chapter 9).

Sanbonmatsu, Lisa, Ludwig, Jens, Katz, Lawrence F., Gennetian, Lisa A., Duncan, Greg J., Kessler, Ronald C., Adam, Emma, McDade, Thomas W., Lindau, Stacy T, 2011. Moving to Opportunity for Fair Housing Demonstration Program: Final Impact Evaluation fullreport.pdf>.

Statistics Denmark, 1992, 1997, 2000. Statistisk Årbog 1992, 1997, 2000 (Statistical Yearbook 1992, 1997, 2000). Statistics Denmark, Copenhagen.

Topa, Giorgio, 2001. Social interactions, local spillovers and unemployment. Review of Economic Studies 68 (2), 261-295.

Wahba, Jackline, Zenou, Yves, 2005. Density, social networks and job search methods: theory and application to Egypt. Journal of Development Economics $78,443-473$.

Weinberg, Bruce A., Reagan, Patricia B., Yankow, Jeffrey J., 2004. Do neighborhoods affect hours worked? Evidence from longitudinal data. Journal of Labor Economics 22 (4), 891-924.

www.Statistikbanken.dk/RASA, BEF5 and INDKP1. 